Prepared in cooperation with the

Rhode Island Department of Environmental Management

Simulation of Hydrologic-System Responses to

Ground-Water Withdrawals in the Hunt-AnnaquatucketPettaquamscutt Stream-Aquifer System, Rhode Island

Open-File Report 2006-1226 



\section{Simulation of Hydrologic-System Responses to Ground-Water Withdrawals in the Hunt-Annaquatucket-Pettaquamscutt Stream-Aquifer System, Rhode Island}

By Paul M. Barlow and Lance J. Ostiguy

Prepared in cooperation with the

Rhode Island Department of Environmental Management

Open-File Report 2006-1226 


\section{U.S. Department of the Interior DIRK KEMPTHORNE, Secretary \\ U.S. Geological Survey \\ P. Patrick Leahy, Acting Director}

\section{U.S. Geological Survey, Reston, Virginia: 2007}

For product and ordering information:

World Wide Web: http://www.usgs.gov/pubprod

Telephone: 1-888-ASK-USGS

For more information on the USGS--the Federal source for science about the Earth, its natural and living resources, natural hazards, and the environment:

World Wide Web: http://www.usgs.gov

Telephone: 1-888-ASK-USGS

Any use of trade, product, or firm names is for descriptive purposes only and does not imply endorsement by the U.S. Government.

Although this report is in the public domain, permission must be secured from the individual copyright owners to reproduce any copyrighted materials contained within this report.

Suggested citation:

Barlow, P.M., and Ostiguy, L.J., 2007, Simulation of hydrologic-system responses to ground-water withdrawals in the Hunt-Annaquatucket-Pettaquamscutt stream-aquifer system, Rhode Island: U.S. Geological Survey Open-File Report 2006-1226, $51 \mathrm{p}$. 


\section{Contents}

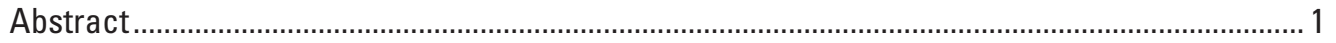

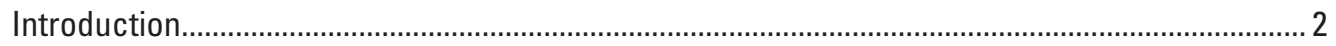

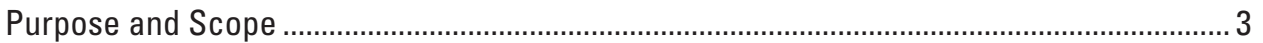

Description of the Study Area and Water-Supply Wells ........................................................ 3

Numerical Models to Simulate Hydrologic-System Responses in the Stream-Aquifer System ... 7

Overview of the Original Numerical Models ..................................................................... 7

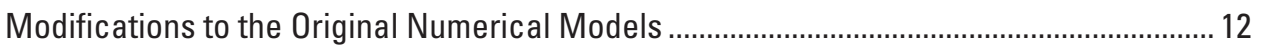

Conversion of Models to MODFLOW-2000 …………….............................................. 12

Increase in the Active Area of the Models ............................................................... 12

Simulation of Flow at Ground-Water Drainage Divides in the

Annaquatucket River Basin .............................................................................. 15

Modification of Aquifer Hydraulic Properties near Lafayette State Fish Hatchery and Town of North Kingstown Well 11 ............................................ 15

Conversion to Constant Saturated Thickness and Transmissivity................................ 16

Simulation of Hydrologic-System Responses in the Stream-Aquifer System ............................... 16

Simulation Results for Original Withdrawal Conditions .................................................... 16

Simulation Results for Alternative Withdrawal and Recharge Conditions ........................... 20

Simulations for Long-Term Average Recharge Conditions............................................ 20

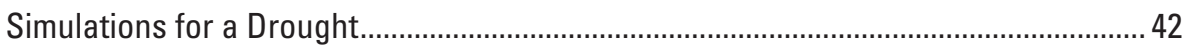

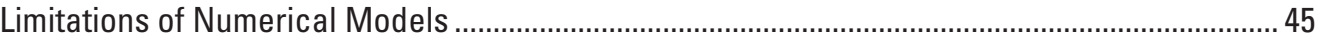

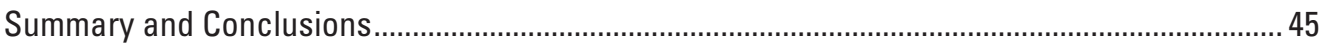

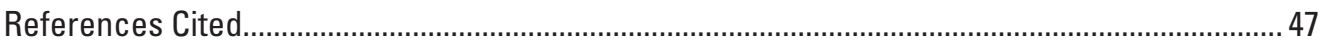

Appendix 1: Withdrawals from Selected Production Wells, 1999-2004 ................................. 49-51

\section{Figures}

1-3. Maps showing-

1. Location of the Hunt-Annaquatucket-Pettaquamscutt stream-aquifer system, Rhode Island

2. Drainage boundaries to the Hunt-Annaquatucket-Pettaquamscutt stream-aquifer system

3. Altitude and configuration of the water table in the Hunt-Annaquatucket-

Pettaquamscutt stream-aquifer system, 0ctober 7-9, 1996

4. Graph showing average monthly withdrawal rates in the Hunt-Annaquatucket-

Pettaquamscutt stream-aquifer system, 2003

5-8. Maps showing-

5. Spatial extent of active area of simulation models of the

Hunt-Annaquatucket-Pettaquamscutt stream-aquifer system.

6. Grid and boundary conditions of the active areas of the modified simulation models of the Hunt-Annaquatucket-Pettaquamscutt stream-aquifer system for $(A)$ rows 3-125, and $(B)$ rows 126-205.

7. Stream sites discussed in text for the Hunt-Annaquatucket-Pettaquamscutt stream-aquifer system

8. Model-calculated steady-state water table with 1996 withdrawal rates, HuntAnnaquatucket-Pettaquamscutt stream-aquifer system 
9-11. Graphs showing-

9. Model-calculated mid-monthly streamflow at the outflow locations of the Hunt and Annaquatucket Rivers.

10. Model-calculated end-of-month streamflow in Queens

Fort Brook at its outflow (site J).

11. Model-calculated end-of-month streamflow in the Annaquatucket

River at its outflow (site P).

12-14. Maps showing-

12. Model-calculated steady-state water table for simulation set 3 (2003 withdrawal rates), Hunt-Annaquatucket-

Pettaquamscutt stream-aquifer system.

13. Model-calculated steady-state drawdowns for simulation set 3

(2003 withdrawal rates), Hunt-Annaquatucket-Pettaquamscutt stream-aquifer system ...

14. Model-grid locations of wetlands near Lafayette State Fish Hatchery.

15. Graphs showing model-calculated end-of-month ground-water

levels at $(A)$ State Fish Hatchery well 3, $(B)$ State Fish Hatchery well 4,

and $(C)$ wetland site $A$

16-21. Maps showing-

16. Model-calculated steady-state contributing areas to water-supply wells in $(A)$ the Hunt River Basin and $(B)$ the Annaquatucket and Pettaquamscutt

River Basins, for simulation set 3 (2003 withdrawal rates)

17. Model-calculated steady-state drawdowns for simulation set 4 (hatchery wells pumping at half their 2003 rates), Hunt-Annaquatucket-Pettaquamscutt stream-aquifer system

18. Model-calculated steady-state drawdowns for simulation set 5 (with State Fish Hatchery well 4 pumping), Hunt-Annaquatucket-Pettaquamscutt stream-aquifer system

19. Model-calculated steady-state water table for simulation set 6 (with State Fish Hatchery well 4 and town of North Kingstown well 11 pumping), HuntAnnaquatucket-Pettaquamscutt stream-aquifer system

20. Model-calculated steady-state drawdowns for simulation set 6 (with State Fish Hatchery well 4 and town of North Kingstown well 11 pumping), Hunt-Annaquatucket-Pettaquamscutt stream-aquifer system

21. Model-calculated steady-state contributing areas to water-supply wells in the Annaquatucket River Basin for simulation set 6 (with State Fish Hatchery well 4 and town of North Kingstown well 11 pumping).

22-24. Graphs showing-

22. Long-term (1941-2003) average and 1957 monthly recharge rates, Hunt-Annaquatucket-Pettaquamscutt stream-aquifer system

23. Model-calculated end-of-month streamflow at the outflow sites of $(A)$ Queens Fort Brook and (B) Annaquatucket River for simulated long-term (1941-2003) average and drought conditions.

24. Model-calculated end-of-month ground-water levels at $(A)$ State Fish Hatchery well 4 and $(B)$ wetland site $A$ for simulated long-term (1941-2003) average and drought conditions 


\section{Tables}

1. Proposed monthly withdrawal rates at Lafayette State Fish Hatchery well SFH4 in the HuntAnnaquatucket-Pettaquamscutt stream-aquifer system, Rhode Island

2. Model grid-cell locations for stream sites discussed in text for the Hunt-AnnaquatucketPettaquamscutt stream-aquifer system.

3. Streamflows specified in the steady-state model of the Hunt-Annaquatucket-

Pettaquamscutt stream-aquifer system.

4. Model-calculated steady-state water-level altitudes and measured water-level altitudes on October 8, 1996, at observation wells in the Hunt-AnnaquatucketPettaquamscutt stream-aquifer system.

5. Model-calculated steady-state average annual hydrologic budgets for the HuntAnnaquatucket-Pettaquamscutt stream-aquifer system.

6. Model-calculated steady-state streamflows at outflow locations from the Hunt-

Annaquatucket-Pettaquamscutt stream-aquifer system

7. Withdrawal rates (2003) specified for water-supply wells in the steady-state model of the Hunt-Annaquatucket-Pettaquamscutt stream-aquifer system

8. Specified ground-water withdrawals and model-calculated streamflows for steady-state simulations

9. Model-calculated ground-water levels near Lafayette State Fish Hatchery for steady-state simulations

10. Model-calculated steady-state flows to and from the aquifer in wetland areas near Lafayette State Fish Hatchery. 
Conversion Table, Datums, and Abbreviations

\begin{tabular}{|c|c|c|}
\hline Multiply & By & To obtain \\
\hline \multicolumn{3}{|c|}{ Length / Area } \\
\hline inch (in.) & 2.54 & centimeter $(\mathrm{cm})$ \\
\hline inch (in.) & 25.4 & millimeter (mm) \\
\hline inch per year (in/yr) & 25.4 & millimeter per year (mm/yr) \\
\hline foot $(\mathrm{ft})$ & 0.3048 & meter $(m)$ \\
\hline mile (mi) & 1.609 & kilometer (km) \\
\hline square mile $\left(\mathrm{mi}^{2}\right)$ & 2.59 & square kilometer $\left(\mathrm{km}^{2}\right)$ \\
\hline \multicolumn{3}{|c|}{ Volume } \\
\hline gallon (gal) & 3.785 & liter $(\mathrm{L})$ \\
\hline \multicolumn{3}{|c|}{ Flow rate } \\
\hline foot per second (ft/s) & 0.3048 & meter per second $(\mathrm{m} / \mathrm{s})$ \\
\hline foot per day (ft/d) & 0.3048 & meter per day $(\mathrm{m} / \mathrm{d})$ \\
\hline foot per year (ft/yr) & 0.3048 & meter per year (m/yr) \\
\hline foot squared per day $\left(\mathrm{ft}^{2} / \mathrm{d}\right)$ & 0.09290 & meter squared per day $\left(\mathrm{m}^{2} / \mathrm{d}\right)$ \\
\hline cubic foot per second $\left(\mathrm{ft}^{3} / \mathrm{s}\right)$ & 0.02832 & cubic meter per second $\left(\mathrm{m}^{3} / \mathrm{s}\right)$ \\
\hline gallon per minute (gal/min) & 0.06309 & liter per second $(\mathrm{L} / \mathrm{s})$ \\
\hline million gallons per day (Mgal/d) & 0.04381 & cubic meter per second $\left(\mathrm{m}^{3} / \mathrm{s}\right)$ \\
\hline \multicolumn{3}{|c|}{ Mass } \\
\hline pound (lb) & 4.536 & kilogram $(\mathrm{kg})$ \\
\hline \multicolumn{3}{|c|}{ Transmissivity } \\
\hline gallon per day per foot $[(\mathrm{gal} / \mathrm{d}) / \mathrm{ft}]$ & 0.01242 & cubic meter per day per meter $\left[\left(\mathrm{m}^{3} / \mathrm{d}\right) / \mathrm{m}\right]$ \\
\hline
\end{tabular}

\section{TEMPERATURE}

Temperature in degrees Celsius $\left({ }^{\circ} \mathrm{C}\right)$ may be converted to degrees Fahrenheit $\left({ }^{\circ} \mathrm{F}\right)$ as follows:

$$
{ }^{\circ} \mathrm{F}=\left(1.8 x^{\circ} \mathrm{C}\right)+32
$$

Temperature in degrees Fahrenheit $\left({ }^{\circ} \mathrm{F}\right)$ may be converted to degrees Celsius $\left({ }^{\circ} \mathrm{C}\right)$ as follows:

$$
{ }^{\circ} \mathrm{C}=\left({ }^{\circ} \mathrm{F}-32\right) / 1.8
$$

\section{VERTICAL DATUM}

Vertical coordinate information is referenced to the National Geodetic Vertical Datum of 1929 (NGVD29), formerly called the Sea Level Datum of 1929.

\section{HORIZONTAL DATUM}

Horizontal coordinate information is referenced to the North American Datum of 1927 (NAD27), unless otherwise noted.

\section{ABBREVIATIONS}

KCWA Kent County Water Authority

NK Town of North Kingstown, Rhode Island

RIDEM Rhode Island Department of Environmental Management

RIEDC Rhode Island Economic Development Corporation

SFH Lafayette State Fish Hatchery 


\title{
Simulation of Hydrologic-System Responses to Ground-Water Withdrawals in the Hunt-Annaquatucket- Pettaquamscutt Stream-Aquifer System, Rhode Island
}

\author{
By Paul M. Barlow and Lance J. Ostiguy
}

\section{Abstract}

A numerical-modeling study was done to better understand hydrologic-system responses to ground-water withdrawals in the Hunt-Annaquatucket-Pettaquamscutt (HAP) stream-aquifer system of Rhode Island. System responses were determined by use of steady-state and transient numerical ground-water-flow models. These models were initially developed in the late 1990s as part of a larger study of the stream-aquifer system. The models were modified to incorporate new data made available since the original study and to meet the objectives of this study. Changes made to the models did not result in substantial changes to simulated ground-water levels, hydrologic budgets, or streamflows compared to those calculated by the original steady-state and transient models.

Responses of the hydrologic system are described primarily by changes in simulated streamflows and ground-water levels throughout the basin and by changes to flow conditions in the aquifer in three wetland areas immediately east of the Lafayette State Fish Hatchery, which lies within the Annaquatucket River Basin in the town of North Kingstown. Ground water is withdrawn from the HAP aquifer at 14 largecapacity production wells, at an industrial well, and at 3 wells operated by the Rhode Island Department of Environmental Management at the fish hatchery. A fourth well has been proposed for the hatchery and an additional production well is under development by the town of North Kingstown.

The primary streams of interest in the study area are the Hunt, Annaquatucket, and Pettaquamscutt Rivers and Queens Fort Brook. Total model-calculated streamflow depletions in these rivers and brook resulting from withdrawals at the production, industrial, and fish-hatchery wells pumping at average annual 2003 rates are about 4.8 cubic feet per second $\left(\mathrm{ft}^{3} / \mathrm{s}\right)$ for the Hunt River, $3.3 \mathrm{ft}^{3} / \mathrm{s}$ for the Annaquatucket River, $0.5 \mathrm{ft}^{3} / \mathrm{s}$ for the Pettaquamscutt River, and $0.5 \mathrm{ft}^{3} / \mathrm{s}$ for Queens Fort Brook. The actual amount of streamflow reduction in the Annaquatucket River caused by pumping actually is less, $1.1 \mathrm{ft}^{3} / \mathrm{s}$, because ground water that is pumped at the fishhatchery wells $\left(2.2 \mathrm{ft}^{3} / \mathrm{s}\right)$ is returned to the Annaquatucket River after use at the hatchery.
One of the primary goals of the study was to evaluate the response of the hydrologic system to simulated withdrawals at the proposed well at the fish hatchery. Withdrawal rates at the proposed well would range from zero during April through September of each year to a maximum of 260 gallons per minute [about 0.4 million gallons per day $(\mathrm{Mgal} / \mathrm{d})$ ] in March of each year. The average annual withdrawal rate at the fish hatchery resulting from the addition of the proposed well would increase by only $0.13 \mathrm{ft}^{3} / \mathrm{s}$, or about 5 percent of the 2003 withdrawal rate. The increased pumping rate at the hatchery would further reduce the average annual flow in Queens Fort Brook by less than $0.05 \mathrm{ft}^{3} / \mathrm{s}$ and in the Annaquatucket River by about $0.1 \mathrm{ft}^{3} / \mathrm{s}$ (which includes some model error).

A new production well in the Annaquatucket River Basin is under development by the town of North Kingstown. A simulated pumping rate of $1.0 \mathrm{Mgal} / \mathrm{d}\left(1.6 \mathrm{ft}^{3} / \mathrm{s}\right)$ at this new well resulted in additional streamflow depletions, compared to those calculated for the 2003 withdrawal conditions, of 0.8 and $0.2 \mathrm{ft}^{3} / \mathrm{s}$ in the Annaquatucket and Pettaquamscutt Rivers, respectively. The source of water for about 30 percent of the well's pumping rate, or about $0.5 \mathrm{ft}^{3} / \mathrm{s}$, is derived from ground-water inflow from the Chipuxet River Basin across a natural ground-water drainage divide that separates the Annaquatucket and Chipuxet River Basins; the remaining $0.1 \mathrm{ft}^{3} / \mathrm{s}$ of simulated pumping consists of reduced evapotranspiration from the water table.

Model-calculated changes in water levels in the aquifer for the various withdrawal conditions simulated in this study indicate that ground-water-level declines caused by pumping are generally less than 5 feet (ft). However, ground-waterlevel declines of as much as $20 \mathrm{ft}$ were calculated near the fish hatchery and of as much as $18 \mathrm{ft}$ were calculated near the new production well in the Annaquatucket River Basin. The larger water-level declines in these two areas are attributed to relatively low values of the transmissivity of the aquifer in these two areas. Average annual ground-water-level declines in the aquifer resulting from the increased withdrawal in the hatchery area are not substantially greater than those for the 2003 average annual pumping conditions. 
Model-calculated hydrologic budgets for the aquifer in the three wetland areas near the fish hatchery indicate that the total inflow rate to each area is reduced by a maximum of $0.3 \mathrm{ft}^{3} / \mathrm{s}$ for the 2003 average annual pumping conditions; these reductions are a maximum of 13 percent of the total inflow rate to each area for non-pumping conditions. The rates of reductions in ground-water flows to the wetland areas are not substantially different for the proposed additional withdrawals at the hatchery.

The transient model also was used to evaluate the effects of a simulated drought condition on streamflow and groundwater levels. The simulated drought condition was based on hydrologic conditions during 1957, which was determined by the Rhode Island Department of Environmental Management to represent a 1-in-25 year drought. For the withdrawal conditions evaluated, the simulated drought caused modelcalculated monthly streamflows in the Annaquatucket River to be reduced by 1.0 to $3.1 \mathrm{ft}^{3} / \mathrm{s}$ compared to those streamflows calculated for long-term average simulation conditions (that is, non-drought conditions). Model-calculated ground-water levels at the proposed well site at the fish hatchery for the drought condition declined by 1.0 to $3.7 \mathrm{ft}$ compared to those levels calculated for non-drought conditions.

Results of the study must be viewed within the limitations of the quality of the data that are available for the Hunt-Annaquatucket-Pettaquamscutt stream-aquifer system and representation of the system with simulation models. Uncertainties in the model simulations result from a variety of factors, including uncertainties in the exact values of the hydraulic properties of the aquifers, rates of recharge to the aquifer, and the approaches used to simulate the many features of the hydrologic system (streams, evapotranspiration, flow conditions at ground-water drainage divides, and so forth).

The precision of the numerical models used in this study to determine hydrologic-system responses to ground-water withdrawals could benefit from refinement of localized information on the wetlands and the geology of the area near the fish hatchery. Model results in the area of the hatchery also would be improved by the use of a finer model-grid discretization to better simulate wetland-aquifer interactions and the impacts of withdrawals on wetlands and streamflow. Use of a finer discretization could be done as part of a broader datacollection and analysis study of wetland and hydrologic conditions at or near the hatchery. As a consequence of the spatial-discretization limitations of the numerical models developed for the HAP stream-aquifer system, the ability of the numerical models to predict hydrologic responses in the vicinity of the hatchery wells is limited. Furthermore, groundwater-flow conditions near the ground-water drainage divide that separates the Annaquatucket and Chipuxet River Basins are largely unknown. The understanding of hydrologic conditions near this divide would be improved by collection of hydrogeologic data in that area.

\section{Introduction}

The State of Rhode Island Department of Environmental Management (RIDEM) operates the Lafayette State Fish Hatchery in the town of North Kingstown, Rhode Island, where about $80,000 \mathrm{lb}$ of rainbow, brown, and brook trout are raised annually for stocking in state rivers, streams, and ponds. Currently (2005), about $1.5 \mathrm{Mgal} / \mathrm{d}$ of ground water is pumped from three water-supply wells at the hatchery (wells SFH1, SFH2, and SFH3; fig. 1). The water is used for hatchery operations and then discharged to the headwater of the Annaquatucket River. RIDEM has proposed to install a fourth well (SFH4) at the hatchery that would be pumped from October through March at a maximum rate of about $260 \mathrm{gal} / \mathrm{min}(0.4 \mathrm{Mgal} / \mathrm{d})$.

The hatchery is located in the Hunt-AnnaquatucketPettaquamscutt (HAP) River Basin of central Rhode Island, a 39.6- $\mathrm{mi}^{2}$ area that lies primarily in the towns of North Kingstown, East Greenwich, and Exeter (fig. 1). The principal ground-water unit in the basin is the HAP aquifer, which is a generally unconfined aquifer composed of stratified sand and gravel sediments that were deposited by glacial meltwater. The stratified deposits are bounded laterally in most locations by till and bedrock uplands; however, in a few areas, the deposits extend into adjoining surface-water and ground-water basins, notably the Usquepaug-Queen and Chipuxet River Basins (fig. 2). A key aspect of the aquifer is its hydraulic connection with overlying rivers, brooks, and ponds, and, in most places, water can move readily between the ground-water and surface-water systems. Because of the importance of this connection, the linked ground-water/surface-water system has been referred to as the HAP stream-aquifer system (Barlow and Dickerman, 2001).

Ground-water withdrawals at the fish hatchery are from the HAP aquifer, which also is the source of water to several production wells in the basin that are operated by the town of North Kingstown, the Rhode Island Economic Development Corporation (RIEDC), and the Kent County Water

Authority (KCWA) (fig. 1). Withdrawals from these and other wells in the basin lower ground-water levels in the aquifer, reduce streamflow in the hydraulically connected rivers and brooks, and can change ground-water-flow conditions within and beneath wetlands. In response to a concern by the RIDEM about the effects of existing and proposed withdrawals at the Lafayette State Fish Hatchery on the hydrology of the HAP stream-aquifer system, the U.S. Geological Survey (USGS) worked in collaboration with the RIDEM during 2005 and 2006 on a study to better understand hydrologicsystem responses to ground-water withdrawals throughout the HAP River Basin. 


\section{Purpose and Scope}

This report describes the results of the USGS/RIDEM study on the effects of existing and proposed withdrawals at the Lafayette State Fish Hatchery and at the other production wells in the basin on the hydrology of the HAP stream-aquifer system. System responses were determined by use of steadystate and transient numerical ground-water-flow models that were developed originally as part of a larger study of the basin by Dickerman and Barlow (1997) and Barlow and Dickerman (2001). The models were modified as part of the current study to account for new hydrogeologic and groundwater-withdrawal data made available since the original study. Responses of the hydrologic system are described in this report primarily by changes in simulated ground-water levels and streamflows throughout the basin and by changes to ground-water-flow conditions in three wetland areas immediately east of the hatchery (fig. 1). Contributing areas and sources of water to simulated wells also are reported for selected withdrawal conditions.

\section{Description of the Study Area and Water- Supply Wells}

In this report, the study area, which is also referred to as the HAP River Basin, is defined as the entire 39.6- $\mathrm{mi}^{2}$ drainage area shown in figures 1 and 2. Of this total area, the HAP stream-aquifer system covers a $19.0-\mathrm{mi}^{2}$ area that lies within parts of the Hunt, Annaquatucket, Cocumcossuc, Pettaquamscutt, Usquepaug-Queen, and Chipuxet River Basins (fig. 2). The Pettaquamscutt River is called the Mattatuxet River in its headwater reaches. The remaining $20.6 \mathrm{mi}^{2}$ of the basin consists of upland areas of till, bedrock, and discontinuous areas of stratified sand and gravel. Till and bedrock also underlie the HAP aquifer. The surface-water drainage area $\left(35.6 \mathrm{mi}^{2}\right)$ is smaller than the total drainage area of the system $\left(39.6 \mathrm{mi}^{2}\right)$ because ground-water and surface-water drainage boundaries are not coincident in the Chipuxet and Usquepaug-Queen River Basins where they adjoin the western boundary of the Annaquatucket River Basin (fig. 2). Surface-water runoff in these two basins drains to the west of the study area, whereas some of the ground water recharged in the basins flows eastward to the HAP aquifer.

The study area consists of a relatively flat valley that contains several large but generally shallow ponds and lakes. Land-surface altitudes in the valley range from about $5 \mathrm{ft}$ above NGVD29 at the downstream end of the Hunt and Pettaquamscutt River Basins to a maximum of about $250 \mathrm{ft}$ in the headwaters of the Usquepaug-Queen River Basin. The valley is bounded by uplands where land-surface altitudes reach a maximum of about $480 \mathrm{ft}$. Average annual total precipitation at a National Oceanic and Atmospheric Administration climatological station in Kingston, Rhode Island, approximately
$6.5 \mathrm{mi}$ southwest of the center of the study area, was $48.2 \mathrm{in}$. during the 63-year period 1941-2003.

A map of the water table was prepared for the HAP aquifer on the basis of water-level measurements made throughout the aquifer on October 7-9, 1996 (fig. 3), which was a period of near-average water-level conditions (Dickerman and Barlow, 1997). Ground water moves through the aquifer in the direction of lower water-level altitudes. The altitude and configuration of the water-table contours (fig. 3) indicate that the general direction of ground-water flow is from the western contact of the HAP aquifer with till and bedrock uplands toward the east, northeast, and southeast. The aquifer is recharged by precipitation, stream leakage, ground-water inflow from adjacent till-bedrock uplands, and by a small amount of wastewater discharge. Under natural conditions, most ground water flows toward, and is discharged at, the streams, ponds, and wetlands in the basin; some ground water also is discharged from the aquifer by evapotranspiration at the water table and by underflow to adjacent ground-water systems. Water-supply wells, however, intercept ground water that would have flowed to natural discharge areas.

Ground water currently is withdrawn from the HAP aquifer from 18 large-capacity water-supply wells. These consist of 14 production wells, an industrial well (well IW, fig. 1), and the 3 fisheries wells. The town of North Kingstown has 10 supply wells (wells NK1-NK10, fig. 1), the RIEDC has 3 wells (wells 3A, 9A, and 14A, fig. 1), and the KCWA has a single well (well KC1, fig. 1). The town of North Kingstown also has an 11th well (NK11) in the Annaquatucket River Basin that has been approved for pumping at a rate of 1.0 Mgal/d (Fay, Spofford, and Thorndike, 2005; Susan Licardi, Director of Water Supply, Town of North Kingstown Water Department, written commun., 2005).

Current withdrawals at the fish hatchery average about 1.4 to $1.5 \mathrm{Mgal} / \mathrm{d}$, and peak at about $1.6 \mathrm{Mgal} / \mathrm{d}$ during December through February (Peter Angelone, Rhode Island Department of Environmental Management, oral commun., 2005). The distribution of total withdrawals among the three wells is approximately 17 percent from well SFH1, 33 percent from well SFH2, and 50 percent from well SFH3 (James McGinn, Rhode Island Department of Environmental Management, written commun., 2005). Withdrawals at the proposed fourth hatchery well would vary through the year, from a rate of zero during April through September to a maximum rate of about $260 \mathrm{gal} / \mathrm{min}(0.4 \mathrm{Mgal} / \mathrm{d}$ ) during March (table 1).

Average daily withdrawals from all existing wells during 2003 were about $6.3 \mathrm{Mgal} / \mathrm{d}$, which was typical for recent (1999-2004) years. Total withdrawals ranged from about 5.1 Mgal/d during November and December to a maximum of about $8.1 \mathrm{Mgal} / \mathrm{d}$ during July (fig. 4). Withdrawals are largest in the Hunt River Basin and smallest in the Pettaquamscutt River Basin. Total monthly withdrawals for each of the 14 production wells during 1999 through 2004 are provided in appendix 1; withdrawals at each well prior to 1999 are provided in Barlow and Dickerman (2001). 


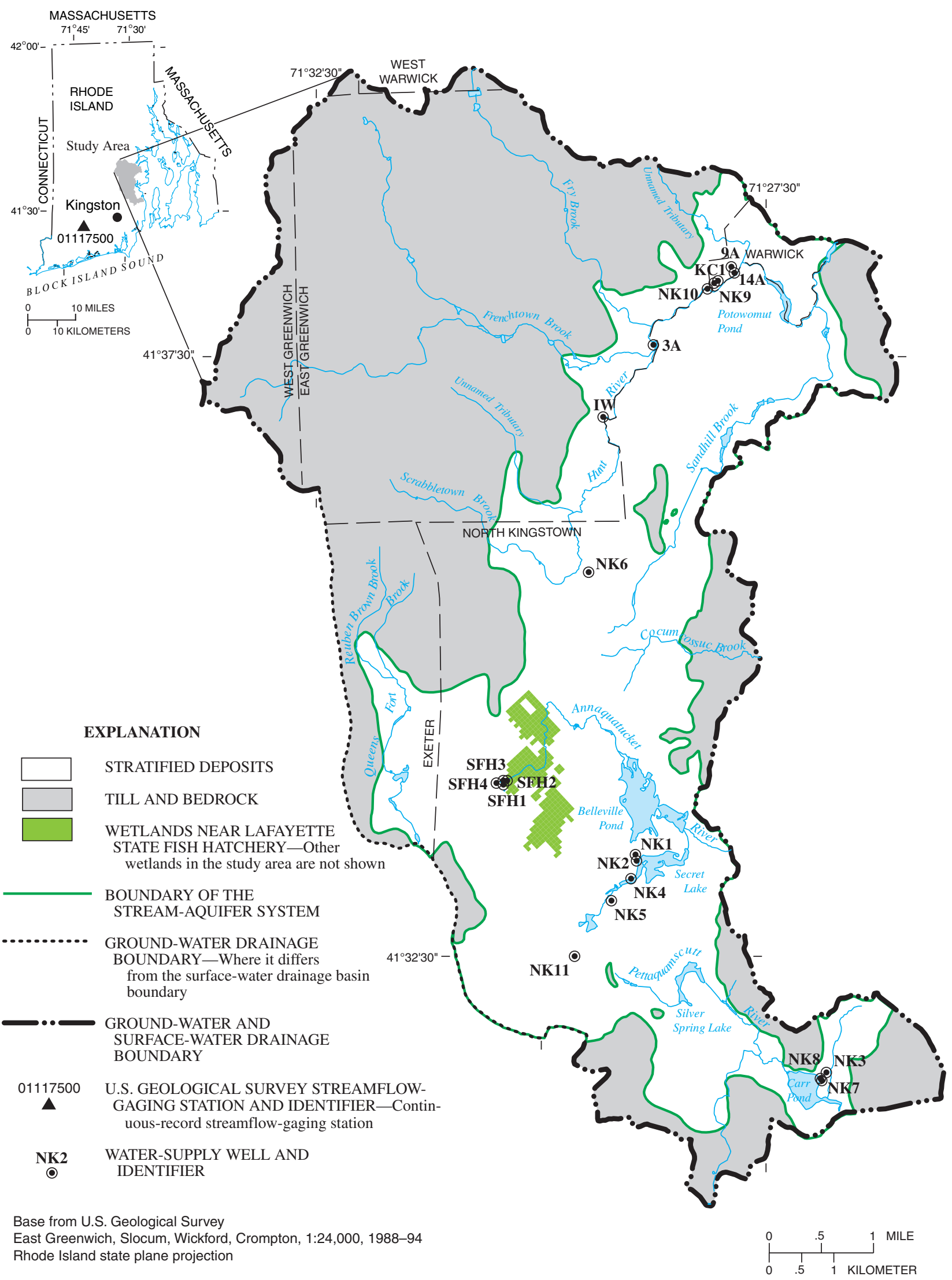

Figure 1. Location of the Hunt-Annaquatucket-Pettaquamscutt stream-aquifer system, Rhode Island. 


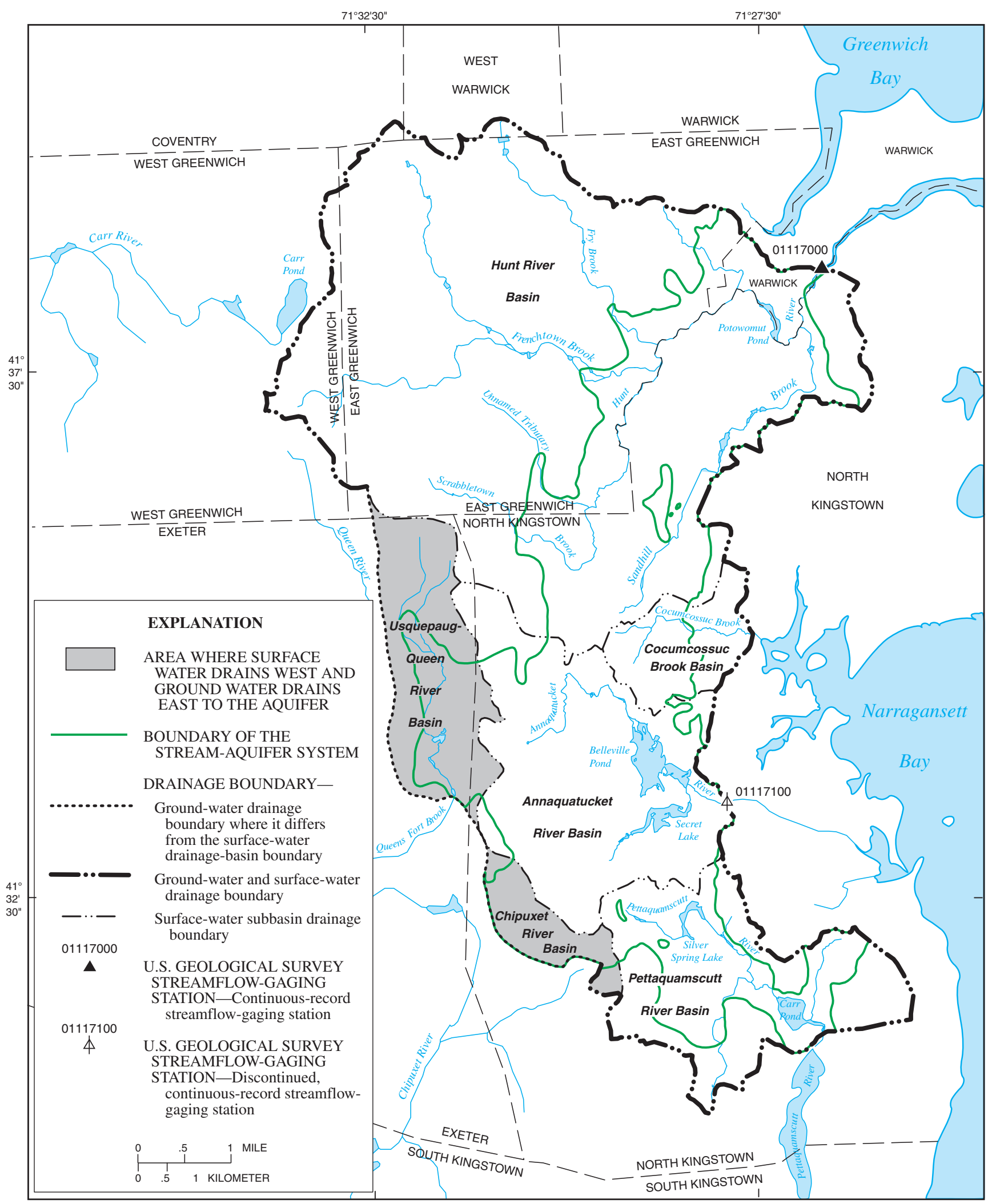

Base from U.S. Geological Survey,

East Greenwich, Slocum, Wickford, Crompton, 1:24,000, 1988-94 Rhode Island state plane projection

Figure 2. Drainage boundaries to the Hunt-Annaquatucket-Pettaquamscutt stream-aquifer system. 


\section{EXPLANATION}

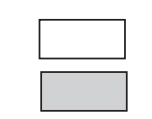

STRATIFIED DEPOSITS

TILL AND BEDROCK

- 100 - - - WATER-TABLE CONTOUR Shows altitude of water table in feet above NGVD29. Dashed where approximately located. Contour interval is variable

\section{BOUNDARY OF THE STREAM- AQUIFER SYSTEM \\ GROUND-WATER DRAINAGE BOUNDARY - Where it differs from the surface-water drainage basin boundary \\ GROUND-WATER AND SURFACE-WATER DRAINAGE BOUNDARY \\ $\stackrel{\text { NK2 }}{0}$ WATER-SUPPLY WELL AND IDENTIFIER \\ LL AND}

Base from U.S. Geological Survey

East Greenwich, Slocum, Wickford,Crompton, 1:24,000, 1988-94

Rhode Island state plane projection 
Table 1. Proposed monthly withdrawal rates at Lafayette State Fish Hatchery well SFH4 in the Hunt-AnnaquatucketPettaquamscutt stream-aquifer system, Rhode Island.

[Withdrawal rate: Proposed withdrawal rates from James McGinn, Rhode Island Department of Environmental Management, written commun., 2005. Well location shown in figure 1]

\begin{tabular}{lcc}
\hline \multirow{2}{*}{ Month } & \multicolumn{2}{c}{ Withdrawal rate } \\
\cline { 2 - 3 } & $\begin{array}{c}\text { Gallons per } \\
\text { minute }\end{array}$ & $\begin{array}{c}\text { Million gallons } \\
\text { per day }\end{array}$ \\
\hline January & 120 & 0.17 \\
February & 200 & .29 \\
March & 260 & .37 \\
April & 0 & 0 \\
May & 0 & 0 \\
June & 0 & 0 \\
July & 0 & 0 \\
August & 0 & 0 \\
September & 0 & 0 \\
October & 20 & .03 \\
November & 20 & .03 \\
December & 90 & .13 \\
\hline
\end{tabular}

\section{Numerical Models to Simulate Hydrologic-System Responses in the Stream-Aquifer System}

Ground-water flow in the HAP aquifer was simulated with the USGS modular three-dimensional finite-difference ground-water-flow model, commonly known as MODFLOW (McDonald and Harbaugh, 1988; Harbaugh and McDonald,
1996; Harbaugh and others, 2000). The original models of the study area used the 1996 version of MODFLOW, but were updated to the 2000 version in the study described here.

\section{Overview of the Original Numerical Models}

The numerical models of the HAP stream-aquifer system are basin-scale models that were developed to simulate ground-water flow throughout the entire HAP system. A brief overview of the original steady-state and transient models of the basin is provided here as background for the modifications to the models described later in this report; Barlow and Dickerman (2001) provide a complete description of the development and calibration of the original models.

Ground-water flow was only simulated in the stratified deposits (fig. 5). The grid used for both the steady-state and transient models was aligned approximately parallel to the northeast-trending valleys of the Hunt River and Sandhill Brook and southwest-trending valley of the Pettaquamscutt River (fig. 6). The models simulated average flow conditions that were presumed to represent the 56-year period 1941-96. The steady-state model simulated long-term average conditions in which there are no storage changes in the simulated system. The transient model simulated average annual conditions using monthly stress periods (January through December). The transient model was designed to simulate dynamic equilibrium, which is the condition in which there is no net change in storage in the simulated system over the average annual hydrologic cycle. Calculated water-level altitudes and streamflows vary over the annual cycle, but at the end of the cycle, the system returns to the condition that existed at the beginning of the cycle. Because initial conditions affect the transient response of the simulated system, it was necessary to repeat the 1 -year cycle until there was no change in

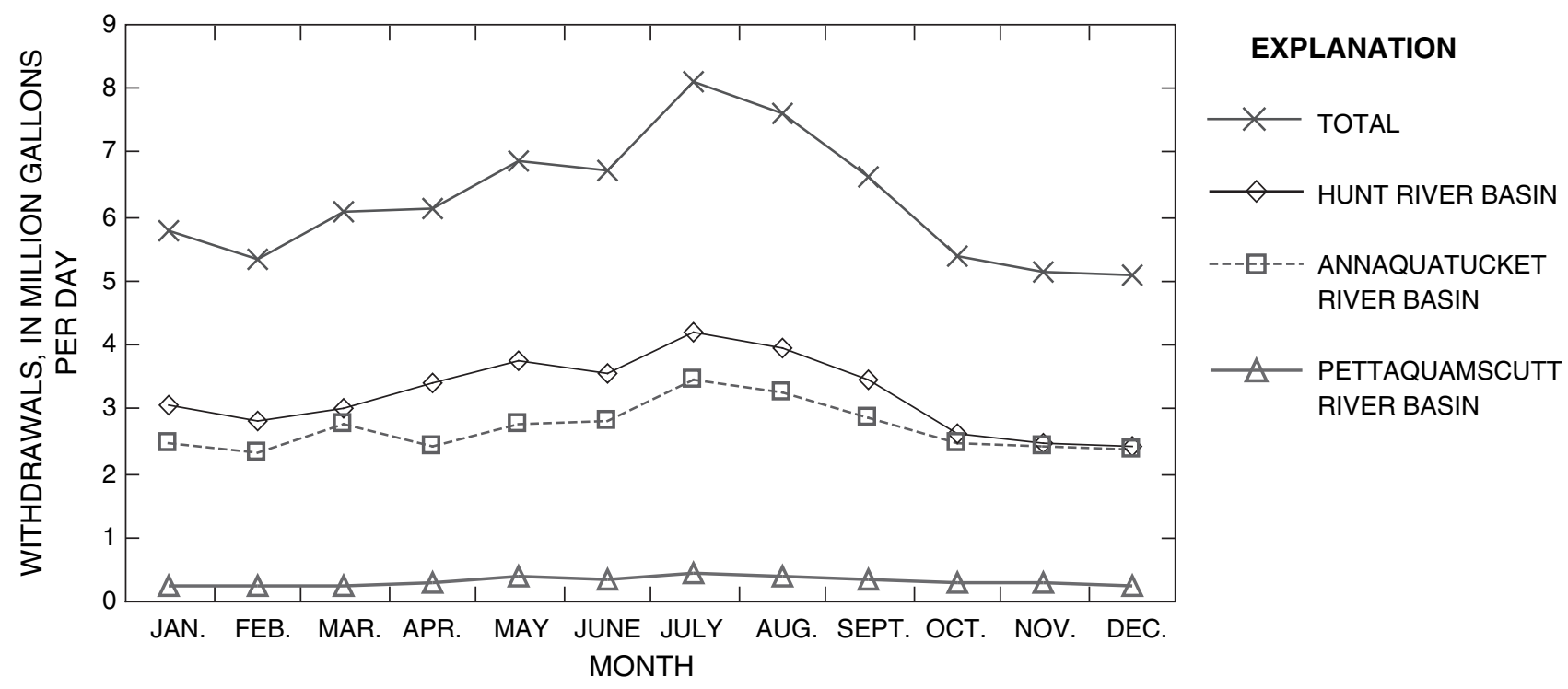

Figure 4. Average monthly withdrawal rates in the Hunt-Annaquatucket-Pettaquamscutt stream-aquifer system, 2003. 


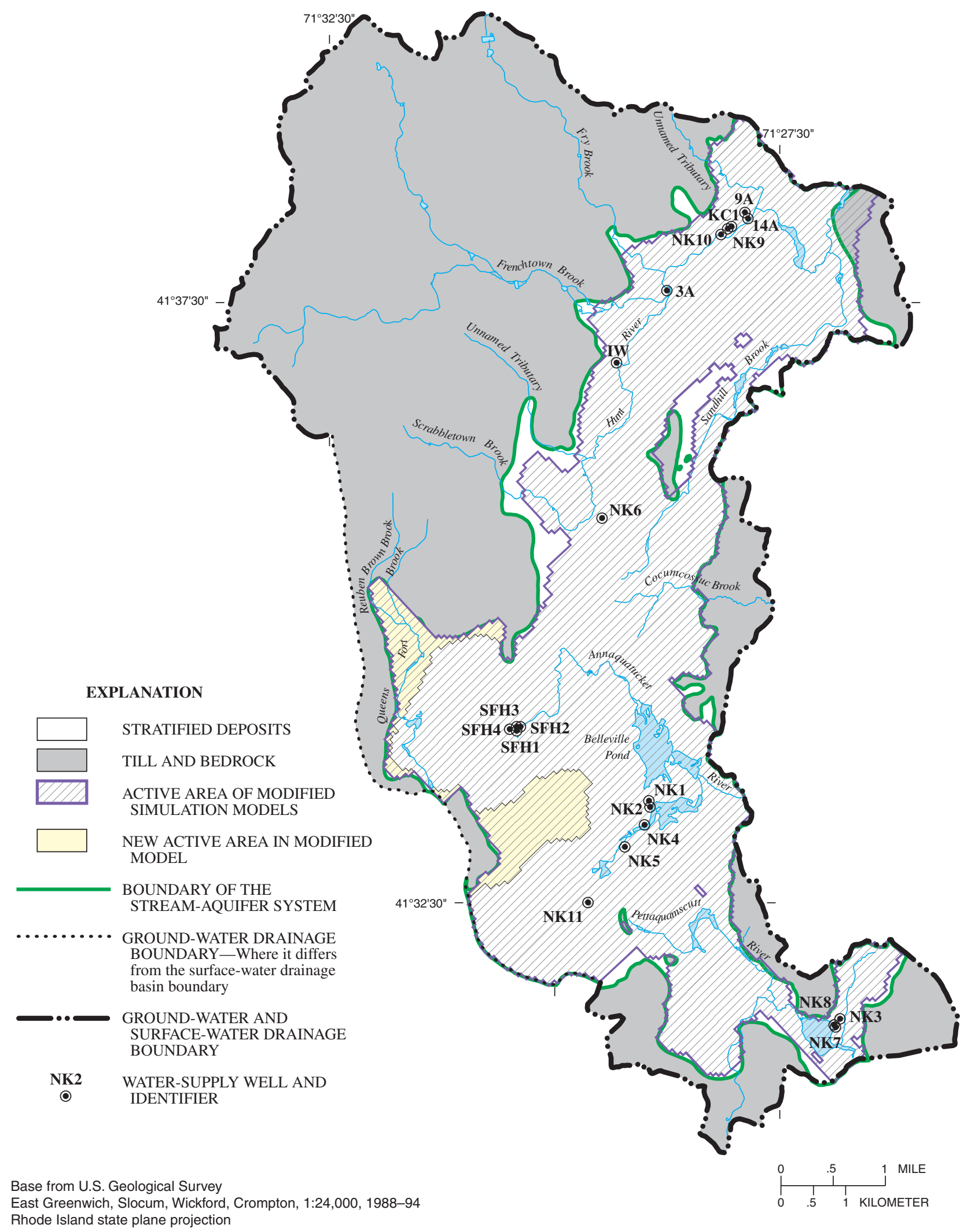

Figure 5. Spatial extent of active area of simulation models of the Hunt-Annaquatucket-Pettaquamscutt stream-aquifer system, Rhode Island. (Modified from Barlow and Dickerman, 2001, fig. 11.) 
storage over the simulated year. It was found that five annual cycles (60 monthly stress periods) were adequate to produce dynamic equilibrium.

The grid consisted of 205 rows and 197 columns of square cells that are $200 \mathrm{ft}$ on each side (fig. 6). In the vertical dimension, the grid consists of a maximum of four layers that extend from the water table to the contact of the HAP aquifer with underlying bedrock. The top layer extends to a maximum depth of $10 \mathrm{ft}$ below the October 1996 elevation of the water table in each cell. This uppermost layer is relatively thin in order to simulate shallow ground-water flow near surfacewater bodies as accurately as possible. The maximum thickness of each of the second and third layers is $30 \mathrm{ft}$; the fourth layer extends from the bottom of the third layer to the HAP aquifer/bedrock contact. Because the thickness of the aquifer varies laterally, the number of active layers within each vertical stack of cells varies laterally as well. Areas of the HAP aquifer where saturated thickness was less than $5 \mathrm{ft}$ were made inactive to ensure numerical stability of the models. This criterion resulted in many cells near the boundary between the HAP aquifer and adjoining till and bedrock uplands being made inactive, and an active area that was smaller than the measured extent of the aquifer (compare boundary of the HAP stream-aquifer system to active area of model in fig. 5).

Horizontal hydraulic conductivity of the simulated stratified deposits of the aquifer ranged from 25 to $587 \mathrm{ft} / \mathrm{d}$. The average horizontal hydraulic conductivity of each layer of the calibrated models ranged from 169 to $191 \mathrm{ft} / \mathrm{d}$.

A uniform anisotropic ratio of horizontal to vertical hydraulic conductivity of 5.0 was used throughout the simulated area. Uniform values of the specific yield and storage coefficient of the aquifer of 0.28 and $3.0 \times 10^{-4}$, respectively, were specified for the stratified deposits. Ponds and lakes were simulated in the top layer of each model by specifying an arbitrarily high value of horizontal hydraulic conductivity $(50,000 \mathrm{ft} / \mathrm{d})$ and a specific yield of 1.0 in those cells in which ponds and lakes are located.

The active area of the models was surrounded laterally by no-flow boundaries. These boundaries were based on the water-table map of the aquifer developed by Dickerman and Barlow (1997) and hydrogeologic information provided in Rosenshein and others (1968), who completed the first comprehensive study of the aquifer. Recharge to the water table was represented as a specified flow rate applied to the uppermost active cell in each vertical stack of cells. A long-term average precipitation recharge rate of $28.0 \mathrm{in} / \mathrm{yr}$ was applied to all areas of the HAP aquifer except those overlain by ponds and lakes, where a recharge rate of $19.5 \mathrm{in} / \mathrm{yr}$ was specified. For the transient model, long-term average monthly recharge rates were specified for all areas of the model except ponds and lakes, where recharge rates were reduced in proportion to seasonal free-water-surface evaporation rates. Recharge from wastewater was specified in those areas of the model that receive water supplies but are unsewered; total recharge from wastewater was about $1.2 \mathrm{ft}^{3} / \mathrm{s}$ (or 3 percent of the total average annual simulated recharge of $35.5 \mathrm{ft}^{3} / \mathrm{s}$ ), and was specified at a constant rate throughout the year.

Ground-water inflow from upland areas not drained by streams was accounted for by injecting water into simulated wells located in the first and second layers of the models just inside the boundary between the HAP aquifer and adjoining till and bedrock; total steady-state inflow along these boundaries was calculated by multiplying the precipitation recharge rate to the aquifer of $28.0 \mathrm{in} / \mathrm{yr}$ by the total area of undrained till and bedrock uplands. For the transient model, these inflow rates were varied in proportion to the monthly precipitation recharge rate to the aquifer. Ground-water underflow where it leaves the system near the Annaquatucket River was accounted for by withdrawing $1.0 \mathrm{ft}^{3} / \mathrm{s}$ of water from simulated wells in the top layer of the steady-state model in that area; for the transient model, this rate was adjusted for each month in proportion to the monthly recharge rate to the aquifer.

Evapotranspiration from the water table was simulated with the evapotranspiration package of MODFLOW. A maximum steady-state evapotranspiration rate from the water table of $21.0 \mathrm{in} / \mathrm{yr}$ and a maximum depth below the land surface at which evapotranspiration takes place of $4 \mathrm{ft}$ were assumed. For the transient model, maximum monthly evapotranspiration rates from the water table were specified as 3.5 inches per month during the May-October growing season and zero for the remaining months of the year.

Average annual and monthly ground-water withdrawals during 1996 were specified at simulated supply wells for the steady-state and transient models, respectively. These withdrawal rates were determined by Barlow and Dickerman (2001, p. 27) to be representative of the 1941-96 period.

Streams were simulated in the models with the streamrouting package developed by Prudic (1989). This package simulates hydraulic interaction between an aquifer and adjoining streams, and tracks the amount of water in each simulated stream. Most of the simulated streams flow through ponds and lakes that are in hydraulic connection with the aquifer; these ponds and lakes also were simulated with the streamrouting package. The grid locations of the several stream sites discussed in this report are summarized in table 2, and their locations are shown in figure 7. Streamflow that enters the HAP stream-aquifer system from upland till and bedrock areas and at the headwater of the Annaquatucket River where water is discharged to the stream at the fish hatchery was specified in the steady-state and transient models. These streamflow rates were either measured directly or were estimated by correlation of streamflows measured at the stream sites to long-term continuous-record streamflow-gaging stations. Locations of specified streamflow are shown in figure 6; the rates of streamflow specified for the steady-state model are given in table 3 . 

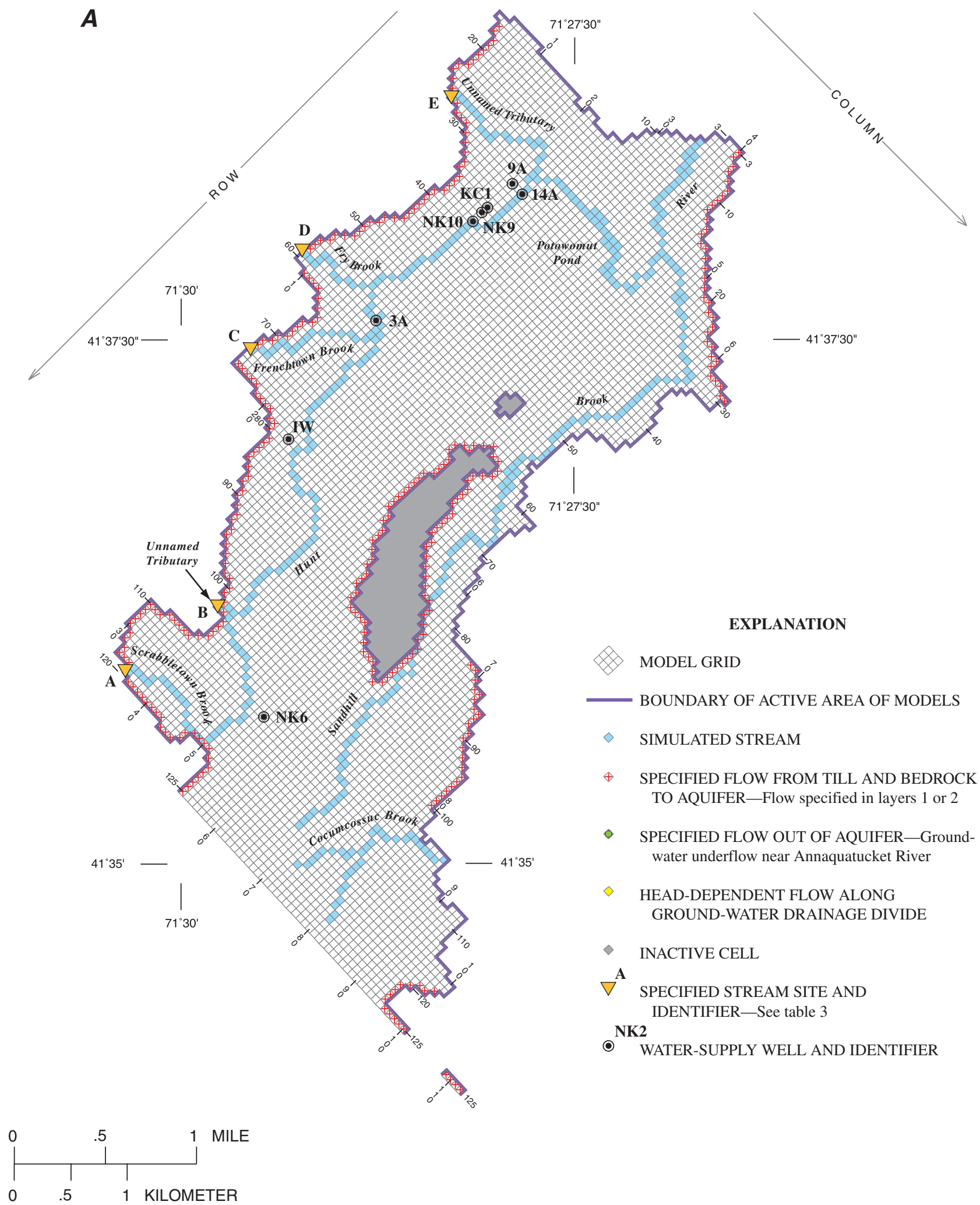

Figure 6. Grid and boundary conditions of the active areas of the modified simulation models of the Hunt-AnnaquatucketPettaquamscutt stream-aquifer system, Rhode Island, for $(A)$ rows 3-125 and $(B)$ rows 126-205. (Modified from Barlow and Dickerman, 2001, fig. 12.) 


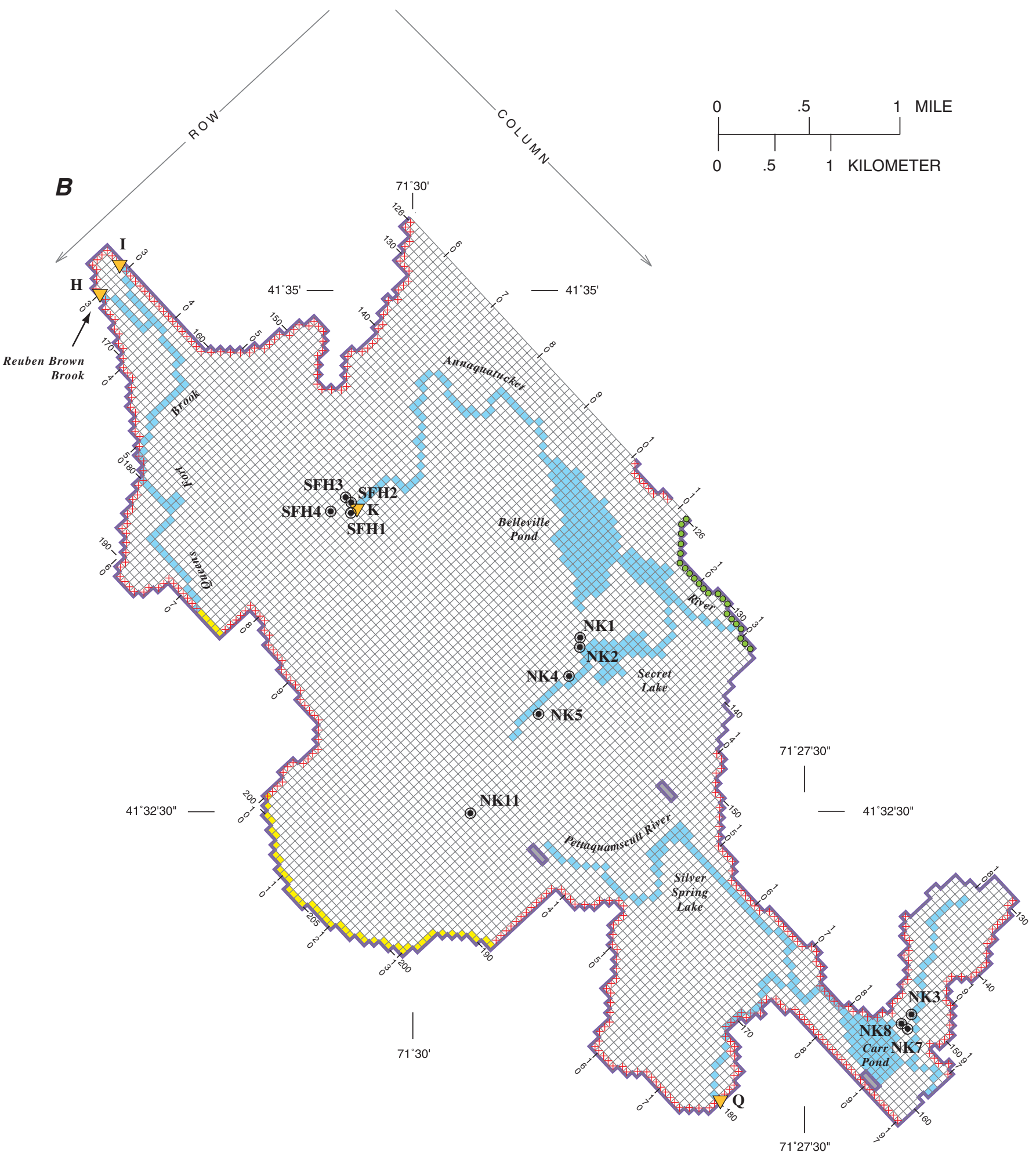

Figure 6. Grid and boundary conditions of the active areas of the modified simulation models of the Hunt-AnnaquatucketPettaquamscutt stream-aquifer system, Rhode Island, for $(A)$ rows 3-125 and $(B)$ rows 126-205. (Modified from Barlow and Dickerman, 2001, fig.12.)-Continued 
Table 2. Model grid-cell locations for stream sites discussed in text for the Hunt-AnnaquatucketPettaquamscutt stream-aquifer system, Rhode Island.

[Site identifiers are shown in figure 7]

\begin{tabular}{|c|c|c|c|c|}
\hline \multirow{2}{*}{$\begin{array}{l}\text { Stream site } \\
\text { identifier }\end{array}$} & \multirow{2}{*}{ Stream name } & \multicolumn{3}{|c|}{ Model cell } \\
\hline & & Layer & Row & Column \\
\hline \multicolumn{5}{|c|}{ Hunt River Basin } \\
\hline $\mathrm{A}$ & Scrabbletown Brook & 1 & 119 & 35 \\
\hline $\mathrm{B}$ & Unnamed tributary $\# 1$ to Hunt River & 1 & 103 & 37 \\
\hline $\mathrm{C}$ & Frenchtown Brook & 1 & 74 & 13 \\
\hline $\mathrm{D}$ & Fry Brook & 1 & 59 & 8 \\
\hline $\mathrm{E}$ & Unnamed tributary $\# 2$ to Hunt River & 1 & 28 & 6 \\
\hline $\mathrm{F}$ & Hunt River outflow & 1 & 6 & 35 \\
\hline \multicolumn{5}{|c|}{ Cocumcossuc Brook Basin } \\
\hline $\mathrm{G}$ & Cocumcossuc Brook outflow & 1 & 104 & 86 \\
\hline \multicolumn{5}{|c|}{ Usquepaug-Queen River Basin } \\
\hline $\mathrm{H}$ & Reuben Brown Brook & 1 & 166 & 30 \\
\hline \multicolumn{5}{|c|}{ Queens Fort Brook: } \\
\hline I & At upland contact & 1 & 161 & 29 \\
\hline $\mathrm{J}$ & At outflow & 1 & 187 & 73 \\
\hline \multicolumn{5}{|c|}{ Annaquatucket River Basin } \\
\hline \multicolumn{5}{|c|}{ Annaquatucket River: } \\
\hline $\mathrm{K}$ & Below State Fish Hatchery & 1 & 160 & 78 \\
\hline $\mathrm{L}$ & Between State Fish Hatchery and Hatchery Road & 1 & 148 & 79 \\
\hline M & Between State Fish Hatchery and Hatchery Road & 1 & 141 & 71 \\
\hline $\mathrm{N}$ & At Hatchery Road & 1 & 133 & 85 \\
\hline $\mathrm{O}$ & Belleville Pond outflow & 1 & 135 & 117 \\
\hline $\mathrm{P}$ & At outflow (Route 1) & 1 & 131 & 129 \\
\hline \multicolumn{5}{|c|}{ Pettaquamscutt River Basin } \\
\hline Q & Unnamed tributary to Pettaquamscutt River & 1 & 180 & 177 \\
\hline $\mathrm{R}$ & Pettaquamscutt River outflow & 1 & 157 & 197 \\
\hline
\end{tabular}

\section{Modifications to the Original Numerical Models}

Several modifications were made to the original models to incorporate new data made available since the original study, or to meet the objectives of this study. These modifications are described below.

\section{Conversion of Models to MODFLOW-2000}

The first step in updating the models was to convert them to the 2000 version of MODFLOW (Harbaugh and others, 2000), so that they run with a more current version of the MODFLOW code. The most substantial change that was required was to replace the Block-Centered Flow (BCF) package of MODFLOW-96 with the Layer-Property Flow (LPF) package of MODFLOW-2000. This change required replacing the vertical conductance of the aquifer specified in the original BCF package by the ratio of horizontal to vertical hydraulic conductivity of the aquifer specified in the LPF package. A uniform ratio of horizontal to vertical hydraulic conductivity of 5.0 was specified for all four layers of the models, which was the same ratio used to calculate vertical conductance in the original models. The second change that was required was the addition of a discretization (DIS) file. Most of the data specified in the DIS file was moved there from the original Basic (BAS) and BCF package files. A top elevation for each cell of layer 1 of the models also was specified in the DIS file; these elevations were set to the estimated water-table elevations during October 1996, which were the elevations used to derive the model-layering intervals in the original model.

\section{Increase in the Active Area of the Models}

The lateral extent of the active area of the models was increased to provide improved representation of the aquifer near the State Fish Hatchery. This was done in two general areas (fig. 5): (1) west of the hatchery toward Queens Fort Brook in the Usquepaug-Queen River Basin and (2) south 
Table 3. Streamflows specified in the steady-state model of the Hunt-Annaquatucket-Pettaquamscutt stream-aquifer system, Rhode Island.

[Site identifiers are shown in figures 6 and 7]

\begin{tabular}{|c|c|c|c|c|c|c|}
\hline \multirow{2}{*}{$\begin{array}{l}\text { Stream site } \\
\text { identifier }\end{array}$} & \multirow[b]{2}{*}{ Stream name } & \multicolumn{3}{|c|}{ Model cell } & \multicolumn{2}{|c|}{ Streamflow } \\
\hline & & Layer & Row & Column & $\begin{array}{l}\text { Cubic feet } \\
\text { per second }\end{array}$ & $\begin{array}{l}\text { Million gallons } \\
\text { per day }\end{array}$ \\
\hline \multicolumn{7}{|c|}{ Hunt River Basin } \\
\hline A & Scrabbletown Brook & 1 & 119 & 35 & 2.25 & 1.45 \\
\hline $\mathrm{B}$ & Unnamed tributary \#1 to Hunt River & 1 & 103 & 37 & 2.95 & 1.91 \\
\hline $\mathrm{C}$ & Frenchtown Brook & 1 & 74 & 13 & 13.50 & 8.73 \\
\hline $\mathrm{D}$ & Fry Brook & 1 & 59 & 8 & 6.40 & 4.14 \\
\hline $\mathrm{E}$ & Unnamed tributary \#2 to Hunt River & 1 & 28 & 6 & .80 & .52 \\
\hline \multicolumn{7}{|c|}{ Usquepaug-Queen River Basin } \\
\hline $\mathrm{H}$ & Reuben Brown Brook & 1 & 166 & 30 & .98 & .64 \\
\hline $\mathrm{I}$ & Queens Fort Brook & 1 & 161 & 29 & .64 & .41 \\
\hline \multicolumn{7}{|c|}{ Annaquatucket River Basin } \\
\hline $\mathrm{K}$ & Annaquatucket River & 1 & 160 & 78 & 1.95 & 1.26 \\
\hline \multicolumn{7}{|c|}{ Pettaquamscutt River Basin } \\
\hline Q & Unnamed tributary to Pettaquamscutt River & 1 & 180 & 177 & .62 & .40 \\
\hline
\end{tabular}

of the hatchery and west of Belleville Pond. These changes increased the active area of the models by about $1.1 \mathrm{mi}^{2}$.

Changes to the lateral extent of the active area of the models necessitated two additional changes to the original models: (1) the locations and rates of inflow from upland areas of till and bedrock and (2) the simulation of two streams in the Usquepaug-Queen River Basin west of the hatchery. As described previously, ground-water inflow from upland areas of till and bedrock that are not drained by streams was simulated by use of injection wells just inside the boundary between active and inactive areas. The amount of inflow from undrained upland areas was decreased from the original model to account for the smaller extent of these areas in the new model. The total reduction in the amount of inflow from upland areas for the steady-state model was about $2.3 \mathrm{ft}^{3} / \mathrm{s}$, which is consistent with a recharge rate in the upland areas of $28.0 \mathrm{in} / \mathrm{yr}$ (as used in the original models) applied over the 1.1- $\mathrm{mi}^{2}$ active area added to the model. For the transient model, monthly rates of lateral inflow along these boundaries were specified in proportion to the monthly recharge rates to the aquifer, as was done in the original model.

The revised active area of the model also necessitated changes to the simulation of Queens Fort and Reuben Brown Brooks in the Usquepaug-Queen River Basin. Streamflow had been simulated for part of Queens Fort Brook in the original models. In the modified models, the length of that brook that was simulated was increased, and a short reach of Reuben Brown Brook, which is tributary to Queens Fort Brook, was included. Streamflow from upland areas drained by these two brooks was specified in the first reach of each brook. For the steady-state model, these flows were calculated on the basis of the drainage area to the first reach of each brook and an assumed average runoff rate of $28.0 \mathrm{in} / \mathrm{yr}$, as was done in the original models. Average annual flows of 0.64 and $0.98 \mathrm{ft}^{3} / \mathrm{s}$ were specified for Queens Fort Brook and Reuben Brown Brook, respectively. These specified flows to the streams were compensated for in the modified models by reducing the specified amounts of ground-water inflow from upland areas where these streams enter the active area of the model by about $1.6 \mathrm{ft}^{3} / \mathrm{s}$.

Specified monthly inflows for Queens Fort and Reuben Brown Brooks for the transient model were determined by use of the annual distribution of specified flows for Fry Brook, which is a small brook that drains upland areas in the Hunt River Basin and whose flow was measured during the original study (site D, fig. 7). The drainage area of this brook is underlain almost entirely by till, as are the drainage areas of Queens Fort and Reuben Brown Brooks upgradient to the active area of the models. Therefore, it was assumed that the annual distribution of monthly inflows to the model would be similar for the three brooks. Long-term average monthly streamflows at the Fry Brook measurement site for the 1941-96 period were estimated in the original study by use of correlation graphs between streamflows measured in the brook and those measured at a continuous-record streamflow-gaging station on the Pawcatuck River at Wood River Junction, Rhode Island. The ratio of each estimated average monthly flow to the estimated long-term average annual flow for the brook was multiplied by the estimated average annual flows for Queens Fort Brook and Reuben Brown Brook to determine the distribution of monthly inflows to the model for the two brooks. The monthly ratios ranged from a low of 0.14 in September to 2.20 in March. 


\section{EXPLANATION}

STRATIFIED DEPOSITS

TILL AND BEDROCK

WETLANDS NEAR LAFAYETTE STATE FISH HATCHERY - Other wetlands in the study are not shown

BOUNDARY OF THE

STREAM-AQUIFER SYSTEM

BOUNDARY OF ACTIVE AREA OF MODEL

DRAINAGE BOUNDARY-

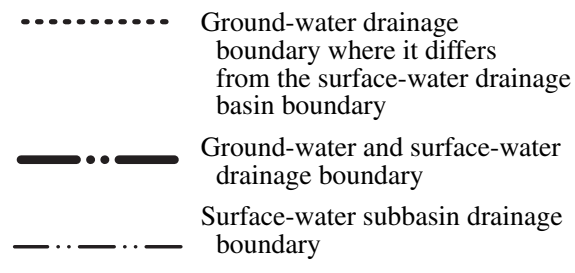

A STREAM SITE

Base from U.S. Geological Survey

East Greenwich, Slocum, Wickford, Crompton, 1:24,000, 1988-94

Rhode Island state plane projection

Figure 7. Stream sites discussed in text for the Hunt-Annaquatucket-Pettaquamscutt stream-aquifer system, Rhode Island. 


\section{Simulation of Flow at Ground-Water Drainage Divides in the Annaquatucket River Basin}

As noted previously, ground-water and surface-water drainage divides do not coincide along the western boundary of the Annaquatucket River Basin where it is in contact with the Usquepaug-Queen and Chipuxet River Basins. Because of this, the active area of the original models was extended into these adjoining basins where they are underlain by stratified deposits. In the original model, the ground-water divides were simulated as no-flow boundaries, which prevented ground water from flowing between the Annaquatucket River Basin and adjoining basins regardless of hydrologic stresses that might occur within the Annaquatucket River Basin. This assumption of no ground-water flow across the drainage divides is valid as long as the locations of ground-water withdrawals in the Annaquatucket River Basin are relatively far from the boundary, which was valid for conditions simulated in the original models. However, the addition of the new well NK11, which was approved since development of the original model, made it necessary to change the type of boundary condition used to simulate flow along the ground-water drainage divides that separate the Annaquatucket River Basin from the Chipuxet River Basin and a small length of the UsquepaugQueen Basin (fig. 6). Instead of the original no-flow boundary condition, head-dependent boundary conditions were specified along these drainage divides by use of the General-Head Boundary (GHB) package of MODFLOW. The use of headdependent boundary conditions allows ground water to flow across the simulated divides in response to changing stress conditions within the model area (but not in the other two basins).

The use of this type of boundary condition requires that ground-water heads be specified at each of the boundary cells. Because of a lack of detailed water-level data in these areas, heads in model cells in all four layers of the model along the boundary were specified on the basis of water-table contours on the October 1996 water-table map and those available in Hahn (1959) and Johnson and Marks (1959). It was also necessary to specify hydraulic conductance at each of these boundary cells. These conductances were calculated as the product of the transmissivity of the aquifer at each cell and the width of each cell (200 ft) divided by the length of each cell (200 ft), which was assumed to be the distance over which the head loss across each drainage divide occurs. The transmissivity of each cell was calculated as the product of the hydraulic conductivity and saturated thickness of the aquifer at each cell, as estimated from maps prepared as part of the study by Rosenshein and others (1968).

\section{Modification of Aquifer Hydraulic Properties near Lafayette State Fish Hatchery and Town of North Kingstown Well 11}

The saturated thickness and hydraulic conductivity of the aquifer were modified in the area near the Lafayette State Fish Hatchery to improve their representation in the model. The modifications were based on a re-evaluation of aquifer conditions near the hatchery as a result of new hydrogeologic data collected during 1995 and 2002 (James McGinn, Rhode Island Department of Environmental Management, written commun., 2005). The modifications consisted of reducing the simulated saturated thickness of the aquifer (by raising the simulated altitude of the bedrock surface) and reducing the simulated hydraulic conductivity of the aquifer near the hatchery from a value of $350 \mathrm{ft} / \mathrm{d}$ specified in the original model to $200 \mathrm{ft} / \mathrm{d}$, which is more consistent with the sand and gravel aquifer sediments found at the hatchery.

Changes also were made to the hydraulic conductivity and transmissivity of the aquifer near well NK11. These changes were made on the basis of new data made available from the results of an aquifer test done at the site by Fay, Spofford, and Thorndike (2005). They calculated transmissivity of the aquifer to be $18,000(\mathrm{gal} / \mathrm{d}) / \mathrm{ft}$ at the site (about 2,400 $\mathrm{ft}^{2} / \mathrm{d}$ ) based on the results of a 72-hour aquifer test.

This transmissivity is low compared to those estimated for some other well locations in the Annaquatucket River Basin, but is consistent with an estimated transmissivity of 20,000 (gal/d)/ft for the aquifer near NK11 given in Rosenshein and others (1968, plate 2). NK11 is in an area mapped as mixed till and outwash (stratified deposits) by Johnson and Marks (1959), who describe these deposits as "till and outwash that grade into one another or are mixed in varying proportions." These deposits are discontinuous and extend generally westward from an area west of Belleville Pond and Secret Lake toward the Chipuxet River Basin (Johnson and Marks, 1959; Hahn, 1959). The mixed sediment type in which the well is apparently located may explain the relatively low transmissivity of the aquifer in that area.

An average hydraulic conductivity of the aquifer at well NK11 can be calculated to be about $24 \mathrm{ft} / \mathrm{d}$ on the basis of the saturated thickness of the aquifer at the site (about $102 \mathrm{ft}$ ) estimated from data provided in Fay, Spofford, and Thorndike (2005). Based on these data, the hydraulic conductivity of the simulated aquifer near the well site was reduced such that the simulated transmissivity of the aquifer in the area of the well is about $2,300 \mathrm{ft}^{2} / \mathrm{d}$. 


\section{Conversion to Constant Saturated Thickness and Transmissivity}

The modifications made to increase the active area of the models caused the updated steady-state model to become numerically unstable. It is assumed that this instability was caused by the relatively thin saturated thickness of the aquifer (generally less than about $30 \mathrm{ft}$ ) in the area west of the State Fish Hatchery in the Usquepaug-Queen River Basin. In fact, the original model was made inactive in that area to avoid these instabilities. Because of the importance of the area in meeting study objectives, it was necessary to simulate the aquifer as having constant saturated thickness and transmissivity at each cell. This approach allows the saturated thickness and transmissivity of the aquifer to vary spatially throughout the model domain, but not in response to changing stress conditions, which include changing withdrawal rates. This assumption often is made in the simulation of water-table aquifers and is considered valid because the saturated thickness (and therefore the transmissivity) of the aquifer does not change substantially in response to changing withdrawal conditions, except within the immediate vicinity of each well (generally less than the 200-ft width of each cell).

This change also required modification to the storage properties of the aquifer for the transient simulations. The storage properties specified in the original transient model were the storage coefficient and specific yield of the aquifer. In the modified transient model, the uniform value of the storage coefficient specified for layers 2-4 of the original model $\left(3.0 \times 10^{-4}\right)$ was replaced by a uniform value of specific storage equal to $1.0 \times 10^{-5} \mathrm{ft}^{-1}$, which was the value used in the original study to calculate storage coefficient. Uniform values of specific yield equal to 0.28 for stratified deposits and 1.0 for ponds and lakes were specified for layer 1 of the original model. For the modified model, these values were divided by $10 \mathrm{ft}$, the original saturated thickness for each cell of layer 1, to obtain a storage property that has units that are consistent with specific storage $\left(\mathrm{ft}^{-1}\right)$, but that retains the high storagecapacity characteristic of a specific yield.

\section{Simulation of Hydrologic-System Responses in the Stream-Aquifer System}

The modified steady-state and transient models described in the previous section were used to simulate several alternative basin-wide withdrawal and recharge conditions. First, the modified models were run using the original 1996 withdrawal conditions to determine how the results of the modified models compare to those of the original models. Then, the modified models were run for several new withdrawal and recharge conditions.

\section{Simulation Results for Original Withdrawal Conditions}

The only change that was made to the models after the modifications described in the previous section was to increase the ground-water levels specified at the head-dependent boundary cells used to simulate the ground-water drainage divide between the Annaquatucket and Chipuxet River Basins. These increases were a maximum of about $7 \mathrm{ft}$, and were made to cause the model-calculated steady-state flow across the divide to be as close to zero as possible, because the boundary is conceptualized as having no ground-water flow across it. The process of having to increase the ground-water levels at this boundary indicates the uncertainty of the exact location of the divide between the Chipuxet and Annaquatucket River Basins.

Calculated water-level altitudes for the original and modified models at each of 22 observation wells used for model calibration are shown with the measured values on October 8, 1996, in table 4. The mean of the absolute value of the difference between calculated and measured water-level altitudes, which is referred to as the mean water-level residual, is about $2.7 \mathrm{ft}$ for each of the two models, which indicates the general similarity between the two models. A map of the simulated water table for steady-state conditions is shown in figure 8. In most areas, differences between the simulated water tables for the original and modified models are small. The areas of noticeable change are those where the lateral extent of the model was increased, west and south of the State Fish Hatchery.

Steady-state average annual hydrologic budgets calculated by the original and modified models are shown in table 5. The total amount of simulated inflow to the two models is identical, although the distribution of flows among the different inflow components differs because of changes made to the lateral extent of the model. In the modified model, lateral ground-water inflow from uplands $\left(15.5 \mathrm{ft}^{3} / \mathrm{s}\right)$ is 4.0 $\mathrm{ft}^{3} / \mathrm{s}$ less than the original model, but this decrease is made up by an increase of $2.4 \mathrm{ft}^{3} / \mathrm{s}$ in simulated recharge to the aquifer and $1.6 \mathrm{ft}^{3} / \mathrm{s}$ in specified streamflow from the uplands at Queens Fort and Reuben Brown Brooks. Ground-water inflows along the two simulated drainage divides between the Annaquatucket River Basin and adjoining Usquepaug-Queen and Chipuxet River Basins for the modified model are about zero; outflows along these drainage divides for the modified model are about $0.2 \mathrm{ft}^{3} / \mathrm{s}$ (table 5).

The total amount of simulated steady-state outflow from the modified model is higher than the original model by $0.6 \mathrm{ft}^{3} / \mathrm{s}$, but the budget error (total inflows minus total outflows) for the modified model is improved over that of the original model. Streamflows calculated by the original and modified models at the five outflow sites reported for the original model are shown in table 6. Differences in calculated streamflows between the original and modified models for the Hunt, Cocumcossuc, and Pettaquamscutt Rivers are 
EXPLANATION

STRATIFIED DEPOSITS

TILL AND BEDROCK

BOUNDARY OF THE STREAM-AQUIFER SYSTEM

BOUNDARY OF ACTIVE AREA OF MODEL

\section{$\cdots \cdots \cdots \cdot$ GROUND-WATER}

DRAINAGE BOUNDARY -

Where it differs from the surfacewater drainage basin boundary

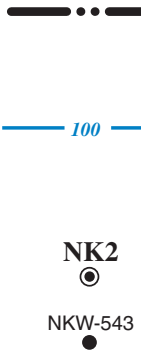

GROUND-WATER AND SURFACE-WATER DRAINAGE BOUNDARY

MODEL-CALCULATED STEADYSTATE WATER-TABLE CONTOURShows altitude of water table in feet above NGVD29. Contour interval is variable

NK2

WATER-SUPPLY WELL AND IDENTIFIER

OBSERVATION WELL AND U.S. GEOLOGICAL

SURVEY IDENTIFIER - Site where model-calculated and measured water-table altitudes were compared See table 4

Base from U.S. Geological Survey

East Greenwich, Slocum, Wickford, Crompton, 1:24,000, 1988-94 Rhode Island state plane projection

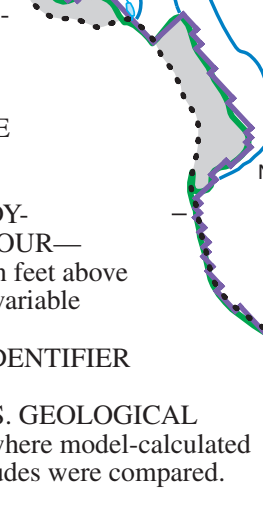


Table 4. Model-calculated steady-state water-level altitudes and measured water-level altitudes on 0ctober 8, 1996, at observation wells in the Hunt-Annaquatucket-Pettaquamscutt stream-aquifer system, Rhode Island.

[Well locations are shown in figure 8. USGS well identifier: EGW, East Greenwich well; EXW, Exeter well; NKW, North Kingstown well; WCW, Warwick well; USGS, U.S. Geological Survey]

\begin{tabular}{|c|c|c|c|c|}
\hline \multirow{2}{*}{$\begin{array}{l}\text { USGS well } \\
\text { identifier }\end{array}$} & \multirow{2}{*}{$\begin{array}{c}\text { Model location } \\
\text { (layer, row, column) }\end{array}$} & \multicolumn{3}{|c|}{$\begin{array}{l}\text { Water-level altitude } \\
\text { (feet above NGVD29) }\end{array}$} \\
\hline & & Measured & Original model & Modified mode \\
\hline WCW-29 & $1,8,33$ & 1.4 & 6.9 & 5.8 \\
\hline WCW-270 & $1,23,31$ & 19.6 & 16.0 & 16.0 \\
\hline NKW-41 & $1,29,49$ & 14.1 & 15.1 & 15.2 \\
\hline NKW-45 & $1,43,43$ & 29.5 & 28.5 & 28.5 \\
\hline EGW-41 & $1,54,19$ & 31.2 & 30.8 & 30.8 \\
\hline NKW-627 & $1,66,28$ & 38.7 & 39.5 & 39.5 \\
\hline NKW-641 & $1,69,43$ & 41.4 & 41.9 & 42.2 \\
\hline NKW-1321 & $1,93,53$ & 45.3 & 49.5 & 49.7 \\
\hline EGW-77 & $1,96,39$ & 43.2 & 43.0 & 43.0 \\
\hline NKW-591 & $1,102,72$ & 52.1 & 53.3 & 54.3 \\
\hline NKW-602 & $1,111,53$ & 47.3 & 53.8 & 54.1 \\
\hline NKW-1320 & $1,117,60$ & 52.0 & 59.4 & 60.3 \\
\hline NKW-512 & $1,130,71$ & 63.1 & 66.4 & 67.9 \\
\hline NKW-1319 & $1,139,83$ & 67.6 & 69.0 & 68.9 \\
\hline NKW-452 & $1,135,133$ & 44.0 & 43.4 & 43.9 \\
\hline NKW-1335 & $2,146,102$ & 57.9 & 52.4 & 53.1 \\
\hline NKW-1333 & $3,150,112$ & 50.1 & 49.7 & 50.2 \\
\hline NKW-1316 & $1,160,148$ & 37.1 & 37.8 & 38.0 \\
\hline NKW-1330 & $2,170,128$ & 68.4 & 65.9 & 65.1 \\
\hline NKW-255 & $1,170,159$ & 36.3 & 40.7 & 44.4 \\
\hline NKW-543 & $2,177,111$ & 93.7 & 89.5 & 91.6 \\
\hline EXW-86 & $2,180,69$ & 172.4 & 169.2 & 172.4 \\
\hline
\end{tabular}


Table 5. Model-calculated steady-state average annual hydrologic budgets for the HuntAnnaquatucket-Pettaquamscutt stream-aquifer system, Rhode Island.

[Budget components are in cubic feet per second]

\begin{tabular}{|c|c|c|}
\hline Hydrologic budget component & Original model & Modified model \\
\hline \multicolumn{3}{|l|}{ Inflow } \\
\hline Recharge & 35.5 & 37.9 \\
\hline Lateral ground-water inflow from uplands & 19.5 & 15.5 \\
\hline Streamflow from uplands & 26.5 & 28.1 \\
\hline Discharge to Annaquatucket River at the State Fish Hatchery & 2.0 & 2.0 \\
\hline Inflow along ground-water drainage divides & .0 & .0 \\
\hline Total inflow & 83.5 & 83.5 \\
\hline \multicolumn{3}{|l|}{ Outflow } \\
\hline Streamflow & 69.3 & 69.5 \\
\hline Evapotranspiration & 4.6 & 4.8 \\
\hline Ground-water underflow near Annaquatucket River & 1.0 & 1.0 \\
\hline Ground-water withdrawal & 8.1 & 8.1 \\
\hline Outflow along ground-water drainage divides & .0 & .2 \\
\hline Total outflow & 83.0 & 83.6 \\
\hline Budget error (inflow-outflow) & .5 & -.1 \\
\hline
\end{tabular}

Table 6. Model-calculated steady-state streamflows at outflow locations from the HuntAnnaquatucket-Pettaquamscutt stream-aquifer system, Rhode Island.

[Streamflow rates are in cubic feet per second; stream site identifiers are shown in figure 7]

\begin{tabular}{clcc}
\hline \multirow{2}{*}{$\begin{array}{c}\text { Stream site } \\
\text { identifier }\end{array}$} & \multicolumn{1}{c}{ Stream name } & \multicolumn{2}{c}{ Streamflow } \\
\cline { 3 - 4 } & Hunt River & 42.3 & Modified model \\
\hline $\mathrm{F}$ & Cocumcossuc Brook & 2.9 & 42.4 \\
$\mathrm{G}$ & Queens Fort Brook & .6 & 2.9 \\
$\mathrm{~J}$ & Annaquatucket River & 13.8 & 1.3 \\
$\mathrm{P}$ & Pettaquamscutt River & 9.7 & 13.3 \\
$\mathrm{R}$ & & 9.6 \\
\hline
\end{tabular}




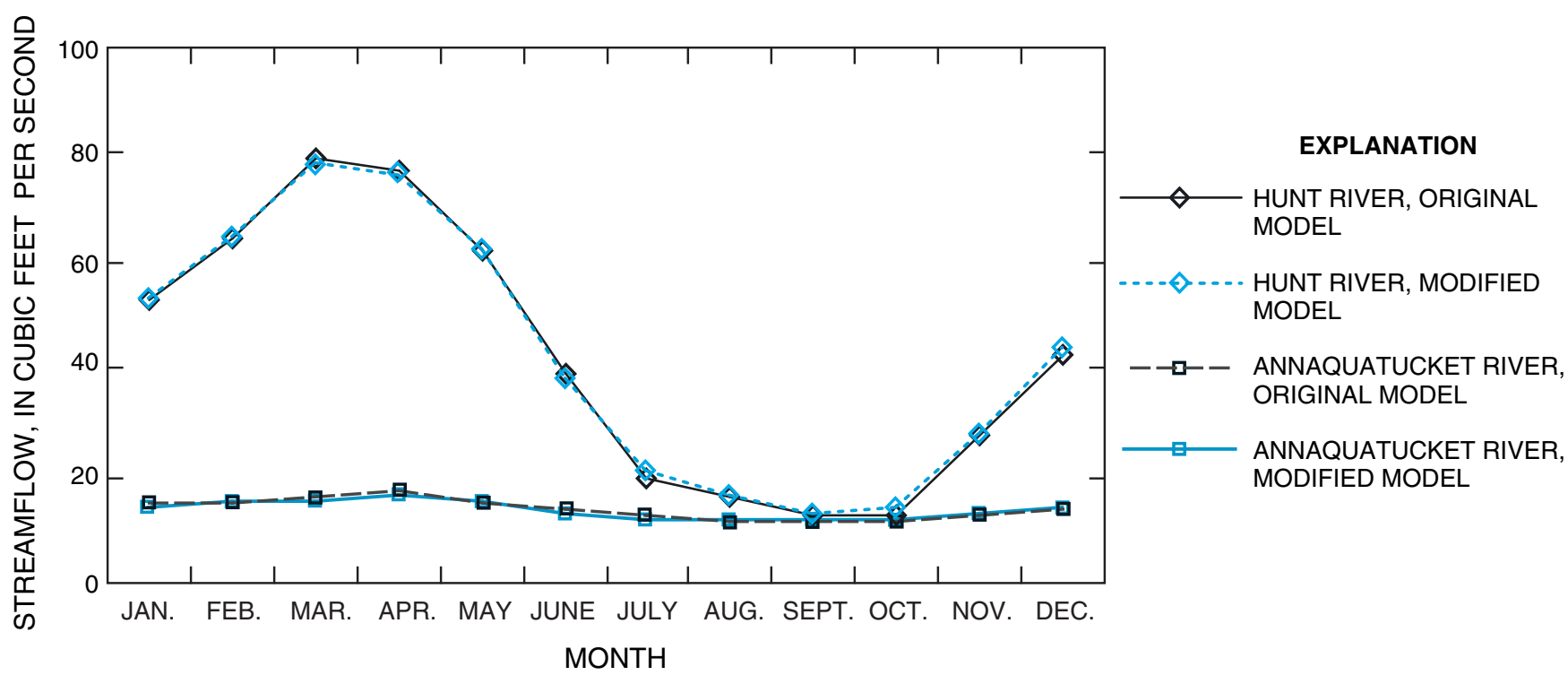

Figure 9. Model-calculated mid-monthly streamflow at the outflow locations of the Hunt and Annaquatucket Rivers, Rhode Island.

less than or equal to $0.1 \mathrm{ft}^{3} / \mathrm{s}$, whereas those for the Annaquatucket River and Queens Fort Brook are $-0.5 \mathrm{ft}^{3} / \mathrm{s}$ and $+0.7 \mathrm{ft}^{3} / \mathrm{s}$, respectively. These differences most likely result from changes made to the model in the Annaquatucket River Basin, particularly those related to extending the active area of the model in the areas west and south of the State Fish Hatchery. Although there is no long-term streamflow gage for the Queens Fort Brook where it leaves the modeled area, a long-term average streamflow of $1.02 \mathrm{ft}^{3} / \mathrm{s}$ has been estimated for a site on the brook about $0.9 \mathrm{mi}$ downstream from the model boundary (USGS streamflow-gaging station 01117365) (Gardner Bent, U.S. Geological Survey, written commun., 2005).

Calculated ground-water levels and streamflows for the modified transient model also are very similar to those calculated for the original transient model. The similarity in model-calculated mid-monthly streamflows for the Hunt and Annaquatucket Rivers at their outflow locations can be seen in figure 9. Mid-monthly streamflows calculated by the modified model for the Annaquatucket River are from 0.3 to $0.9 \mathrm{ft}^{3} / \mathrm{s}$ lower than those calculated by the original model, which is consistent with the lower streamflow calculated for the river by the modified steady-state model. Model-calculated groundwater inflows along the simulated ground-water drainage divides at the end of each month range from zero in February through June to a maximum of $0.4 \mathrm{ft}^{3} / \mathrm{s}$ in October; groundwater outflows range from zero in September and November to a maximum of about $0.7 \mathrm{ft}^{3} / \mathrm{s}$ in April.

\section{Simulation Results for Alternative Withdrawal and Recharge Conditions}

The modified models were used to simulate several alternative withdrawal and recharge conditions. The majority of simulations are for long-term (1941-2003) average recharge conditions; two additional simulations were made to evaluate the effects of drought on the hydrologic system.

\section{Simulations for Long-Term Average Recharge Conditions}

Six sets of simulations were made with the steadystate and transient models for long-term average recharge conditions to determine the effects of alternative basin-wide withdrawal conditions on the ground-water and surface-water resources of the HAP stream-aquifer system. Simulation conditions represent long-term average annual and average monthly hydrologic conditions. Long-term average hydrologic conditions are defined as those that existed during the 63-year period 1941-2003, which extends the 56-year period (1941-96) used in the original models. The simulations progress from a condition of minimum stress, in which there are no ground-water withdrawals anywhere in the HAP Basin, to a condition of maximum stress in which withdrawals occur simultaneously at all existing supply wells in the basin and at two proposed or new wells in the Annaquatucket River Basin. 
The alternative stress conditions allow the effects of different groups of wells and of different pumping rates on the hydrologic system to be isolated. The effects of withdrawals are described in terms of their effects on ground-water levels and streamflows in the basin and on the flow rates to the aquifer underlying three wetland areas near the fish-hatchery wells. The six sets of simulations are:

1. No withdrawals at any supply wells;

2. Withdrawals at 2003 rates at existing production wells only;

3. Withdrawals at 2003 rates at existing production and State Fish Hatchery wells;

4. Withdrawals at existing production wells at 2003 rates and State Fish Hatchery wells at half their 2003 rates;

5. Withdrawals at 2003 rates at existing production and State Fish Hatchery wells and additional withdrawals at proposed State Fish Hatchery well; and

6. Withdrawals at 2003 rates at existing production and State Fish Hatchery wells and additional withdrawals at the proposed State Fish Hatchery well and new town of North Kingstown well.

Long-term average recharge rates to the aquifer were calculated for the 1941-2003 period by use of the computer program RORA (Rutledge, 1993). The program calculates average annual and monthly recharge rates on the basis of continuous streamflow records available for the Hunt River at its outflow location from the study area (USGS streamflowgaging station 01117000; location shown in fig. 2). The average annual recharge rate calculated for the 63-year period was $25.5 \mathrm{in}$., or $0.1 \mathrm{in}$. greater than the value of $25.4 \mathrm{in}$. calculated for the 56-year period in the original study. Average monthly recharge rates for the 63 -year period ranged from a minimum of 0.6 in. for September to 4.3 in. for March, as they did for the 1941-96 period. The maximum difference in the average monthly recharge rate between the 1941-96 and 1941-2003 periods was $0.1 \mathrm{in}$. for the month of June. Because of the similarity in the long-term average annual and monthly recharge rates estimated for the two time periods, recharge rates simulated in the original steady-state and transient models were not changed for the simulations described below. Moreover, other flow-related boundary conditions specified in the steady-state and transient models also were not changed from the original models. These include (1) specified rates of lateral ground-water inflow from uplands; (2) specified rates of streamflow from upland areas to streams entering the modeled area; (3) ground-water underflow near the Annaquatucket River outflow from the basin; and (4) evapotranspiration rates from the water table. Approaches used to estimate each of these boundary conditions are described in detail by Barlow and Dickerman (2001). Because wastewater recharge is a small part of the total recharge to the aquifer, the rate of wastewater recharge was not varied for the six sets of simulations. Discharge rates from the hatchery to the headwater of the Annaquatucket River at stream site K (location shown in fig. 7) were set equal to total withdrawal rates from the hatchery wells, as was done in the original study; these discharge rates were varied from simulation to simulation, as described below.

Most of the simulations described below are based on the 2003 average annual and average monthly pumping rates for each well, which were obtained from the three water suppliers in the basin (Town of North Kingstown, RIEDC, and KCWA) and from the RIDEM. The pumping rate specified for the industrial well (site IW in fig. 1) was not changed from the original model $(0.25 \mathrm{Mgal} / \mathrm{d})$. Average annual withdrawal rates at each well simulated in the models are shown in table 7 and are fairly typical for recent years (1999-2004). Withdrawals at the hatchery represent about 54 percent of the 2003 total average annual withdrawals from the Annaquatucket River Basin. Total average annual ground-water withdrawals from each basin were greater in 2003 than in 1996, increasing from 2.78 to $3.28 \mathrm{Mgal} / \mathrm{d}$ in the Hunt River Basin, from 2.25 to $2.71 \mathrm{Mgal} / \mathrm{d}$ in the Annaquatucket River Basin, and from 0.21 to $0.33 \mathrm{Mgal} / \mathrm{d}$ in the Pettaquamscutt River Basin.

Steady-state contributing areas also were delineated for the production and fish-hatchery wells for two of the simulation conditions described below. The contributing area of a well is the surface area of the water table where recharge water entering the ground-water system eventually flows to the well. Contributing areas were delineated with the computer program MODPATH (Pollock, 1994), which calculates three-dimensional flow paths from the results of the MODFLOW steady-state simulation. MODPATH uses a particletracking scheme to track the movement of hypothetical particles of water through the simulated ground-water-flow system. MODPATH requires specification of the porosity of the aquifer for each cell of the model grid. As in the original study, a uniform porosity of 0.35 was specified for the stratified deposits simulated by the model, and a porosity of 1.0 was specified for the simulated ponds and lakes. The contributing area to each well was delineated by overlaying a $2 \times 2$ array of particles onto the simulated water table in each model cell. Particles were then tracked from the water table to their points of discharge from the simulated aquifer. The origin of those particles that were captured by each simulated well defined the contributing area to that well.

\section{Simulation Set 1: No Withdrawals at Any Supply}

Wells-The first set of model runs, which simulated the condition of no ground-water withdrawals at any of the supply wells in the HAP Basin, was done primarily to provide base-line conditions against which the alternative withdrawal scenarios could be compared. Because there were no withdrawals from the hatchery wells for this simulation set, there was no discharge of water from the hatchery specified to the headwater of the Annaquatucket River. Under this condition, the steady-state model indicates that the Annaquatucket River would be dry from its headwater to below the Hatchery Road stream site (site N, table 8), which is just above Belleville 
Table 7. Withdrawal rates (2003) specified for water-supply wells in the steady-state model of the Hunt-Annaquatucket-Pettaquamscutt stream-aquifer system, Rhode Island.

[Well locations are shown in figure 1; KCWA, Kent County Water Authority; NK, town of North Kingstown; SFH, Lafayette State Fish Hatchery]

\begin{tabular}{|c|c|c|c|c|c|}
\hline \multirow[b]{2}{*}{$\begin{array}{l}\text { Water supply } \\
\text { well identifier }\end{array}$} & \multicolumn{3}{|c|}{ Model cell } & \multicolumn{2}{|c|}{ Withdrawal rate } \\
\hline & Layer & Row & Column & $\begin{array}{l}\text { Cubic feet } \\
\text { per second }\end{array}$ & $\begin{array}{c}\text { Million } \\
\text { gallons per } \\
\text { day }\end{array}$ \\
\hline \multicolumn{6}{|c|}{ Hunt River Basin } \\
\hline $\mathrm{KC1}$ & 4 & 35 & 21 & 1.00 & 0.64 \\
\hline $3 \mathrm{~A}$ & 4 & 58 & 22 & .34 & .22 \\
\hline $9 \mathrm{~A}$ & 2 & 30 & 21 & .33 & .21 \\
\hline $14 \mathrm{~A}$ & 3 & 30 & 23 & .37 & .24 \\
\hline NK6 & 3 & 109 & 53 & .99 & .64 \\
\hline NK9 & 4 & 36 & 21 & 1.67 & 1.08 \\
\hline NK10 & 4 & 38 & 21 & 0 & 0 \\
\hline IW & 3 & 79 & 26 & .39 & .25 \\
\hline Total for basin & & & & 5.09 & 3.28 \\
\hline \multicolumn{6}{|c|}{ Annaquatucket River Basin } \\
\hline $\mathrm{SFH}^{1}{ }^{1}$ & 2 & 161 & 78 & 0.37 & 0.24 \\
\hline $\mathrm{SFH} 2^{1}$ & 2 & 160 & 77 & .74 & .48 \\
\hline SFH3 & 2 & 160 & 76 & 1.11 & .72 \\
\hline SFH4 & 2 & 163 & 76 & 0 & 0 \\
\hline NK1 & 2 & 149 & 114 & .76 & .49 \\
\hline NK2 & 2 & 150 & 115 & .31 & .20 \\
\hline NK4 & 2 & 154 & 117 & .48 & .31 \\
\hline NK5 & 3 & 161 & 118 & .42 & .27 \\
\hline NK11 & 4 & 178 & 122 & 0 & 0 \\
\hline Total for basin & & & & 4.19 & 2.71 \\
\hline \multicolumn{6}{|c|}{ Pettaquamscutt River Basin } \\
\hline NK3 & 3 & 151 & 187 & 0.17 & 0.11 \\
\hline NK7 & 3 & 153 & 188 & .17 & .11 \\
\hline NK8 & 3 & 153 & 187 & .17 & .11 \\
\hline Total for basin & & & & .51 & .33 \\
\hline Total for all basins & & & & 9.79 & 6.32 \\
\hline
\end{tabular}

Pond (fig. 7). Results of the transient simulation also indicated that the river would be mostly dry in this reach during an average year (that is, the condition simulated by the transient model). These dry conditions result from the fact that modelcalculated ground-water levels in the aquifer are lower than the stream stage along most of this reach. Because discharge from the hatchery occurred during all measurement periods in the original study, there are no data to confirm these simulation results directly; however, existing data indicate that the river is losing water to the aquifer under some flow conditions in the reach from just below the hatchery to the Hatchery Road stream site (site N) (Dickerman and Barlow, 1997; Barlow and Dickerman, 2001). This implies that ground-water levels beneath the river are lower than the stream stage in this reach; this was confirmed by water-level data measured at the Hatchery Road stream site (site N) in October 1996 that showed that the water table was more than $4.5 \mathrm{ft}$ below the stream stage in this area. This losing condition suggests that if discharge from the hatchery was discontinued, the river would be dry, or at least intermittent, above the Hatchery Road site for most hydrologic conditions.

There are large model-calculated increases in groundwater discharge to the Annaquatucket River from below the Hatchery Road stream site, through Belleville Pond, to the river's outflow location from the study area (table 8 ). These increases, which are supported by field measurements made 
Table 8. Specified ground-water withdrawals and model-calculated streamflows for steady-state simulations.

[Withdrawals and streamflows are in cubic feet per second. Stream site identifiers (in parentheses) are shown in figure 7; NK, town of North Kingstown; SFH, Lafayette State Fish Hatchery]

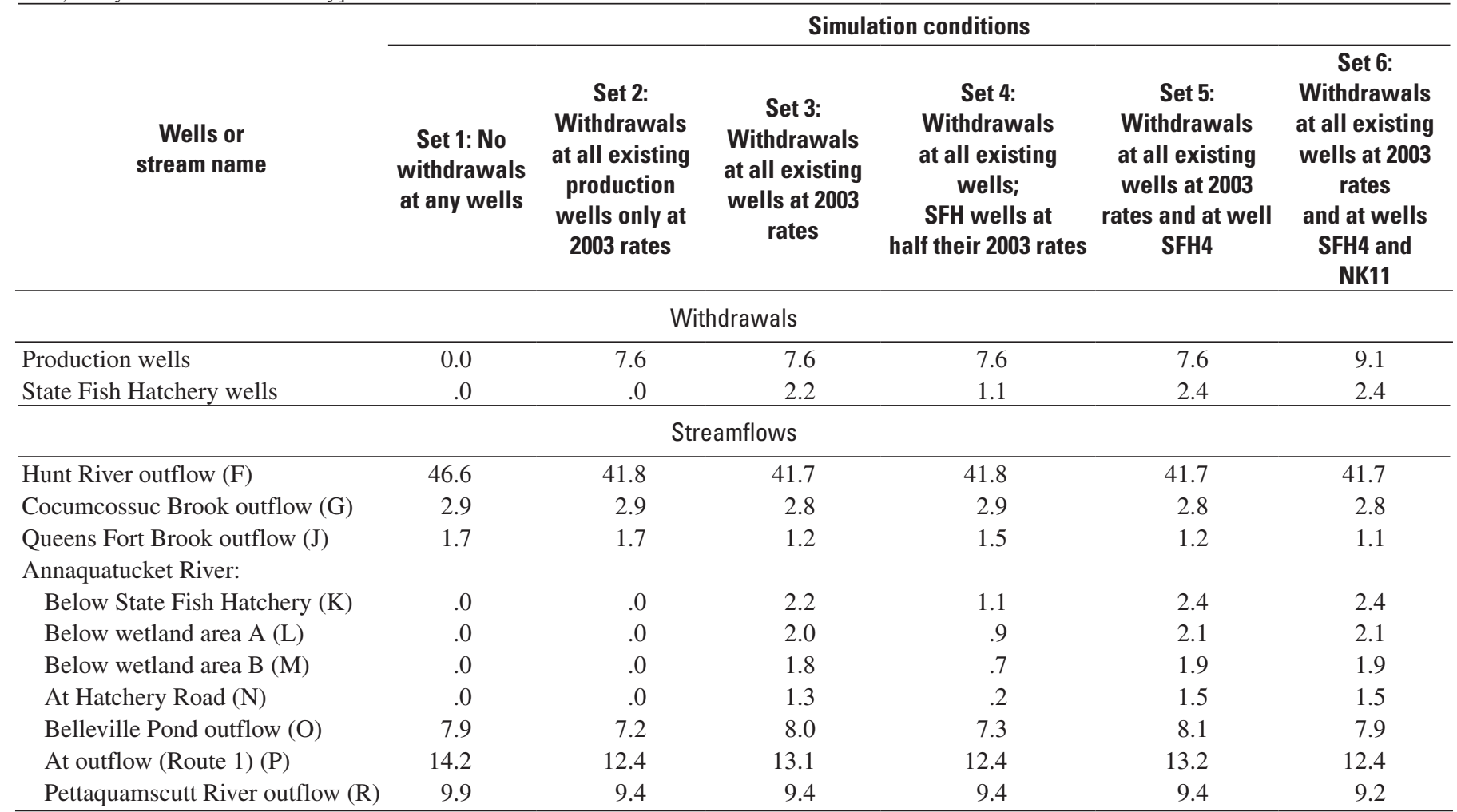

during the original study, are the result of the large groundwater drainage area west of the pond and upgradient to the outflow location.

The average annual (steady-state) flow in Queens Fort Brook at its outflow location from the study area (site $\mathrm{J}$, fig. 7) calculated by the model for the no-withdrawal condition is $1.7 \mathrm{ft}^{3} / \mathrm{s}$ (table 8), and ranges from zero from August through December to a maximum of $5.9 \mathrm{ft}^{3} / \mathrm{s}$ in March (fig. 10). The zero-streamflow calculations from August through December are consistent with streamflow data provided in Kliever (1995, p. 65) for Queens Fort Brook at the USGS streamflow-gaging station 01117365 about $0.9 \mathrm{mi}$ downstream from the model boundary. Those data indicate that of 13 streamflow measurements made during August through December from 1988 through 1991, only one (on November 20, 1989) was greater than zero. It should be noted that the numerical model only calculates the ground-water discharge component (referred to as the base-flow component) of streamflow in Queens Fort Brook, and does not simulate direct surface-water runoff. Nevertheless, the agreement between the model-calculated zero flow and the available streamflow data suggests that surface-water runoff to the brook, at least from August through December, is a relatively small component of total flow in the brook.
Model-calculated steady-state inflows and outflows along the simulated ground-water drainage divides between the Annaquatucket River Basin and the adjoining Usquepaug-Queen and Chipuxet River Basins are 0.0 and $0.1 \mathrm{ft}^{3} / \mathrm{s}$, respectively; for transient conditions, they range to a maximum inflow of $0.4 \mathrm{ft}^{3} / \mathrm{s}$ in October and maximum outflow of $0.8 \mathrm{ft}^{3} / \mathrm{s}$ in April.

Simulation Set 2: Withdrawals at 2003 Rates at Existing Production Wells Only_-In this second set of model runs, withdrawals were specified at 2003 rates from the 14 existing production wells and the industrial well; withdrawals were set to zero at the hatchery wells. These simulations were done to isolate the effects of the existing production-well withdrawals on the hydrologic system. Total simulated average annual withdrawals from the supply wells were $4.9 \mathrm{Mgal} / \mathrm{d}\left(7.6 \mathrm{ft}^{3} / \mathrm{s}\right)$, and ranged from 3.6 Mgal/d in December to 6.7 Mgal/d in July.

For long-term average steady-state conditions, nearly all of the water withdrawn by the wells $\left(7.1 \mathrm{ft}^{3} / \mathrm{s}\right)$ is derived from depletion of streamflow throughout the HAP Basin, with the remainder derived from reduced ground-water evapotranspiration $\left(0.1 \mathrm{ft}^{3} / \mathrm{s}\right)$ or from undetermined model errors $\left(0.4 \mathrm{ft}^{3} / \mathrm{s}\right)$. These model errors are generally small mass-balance errors caused by a number of factors, including rounding of the 

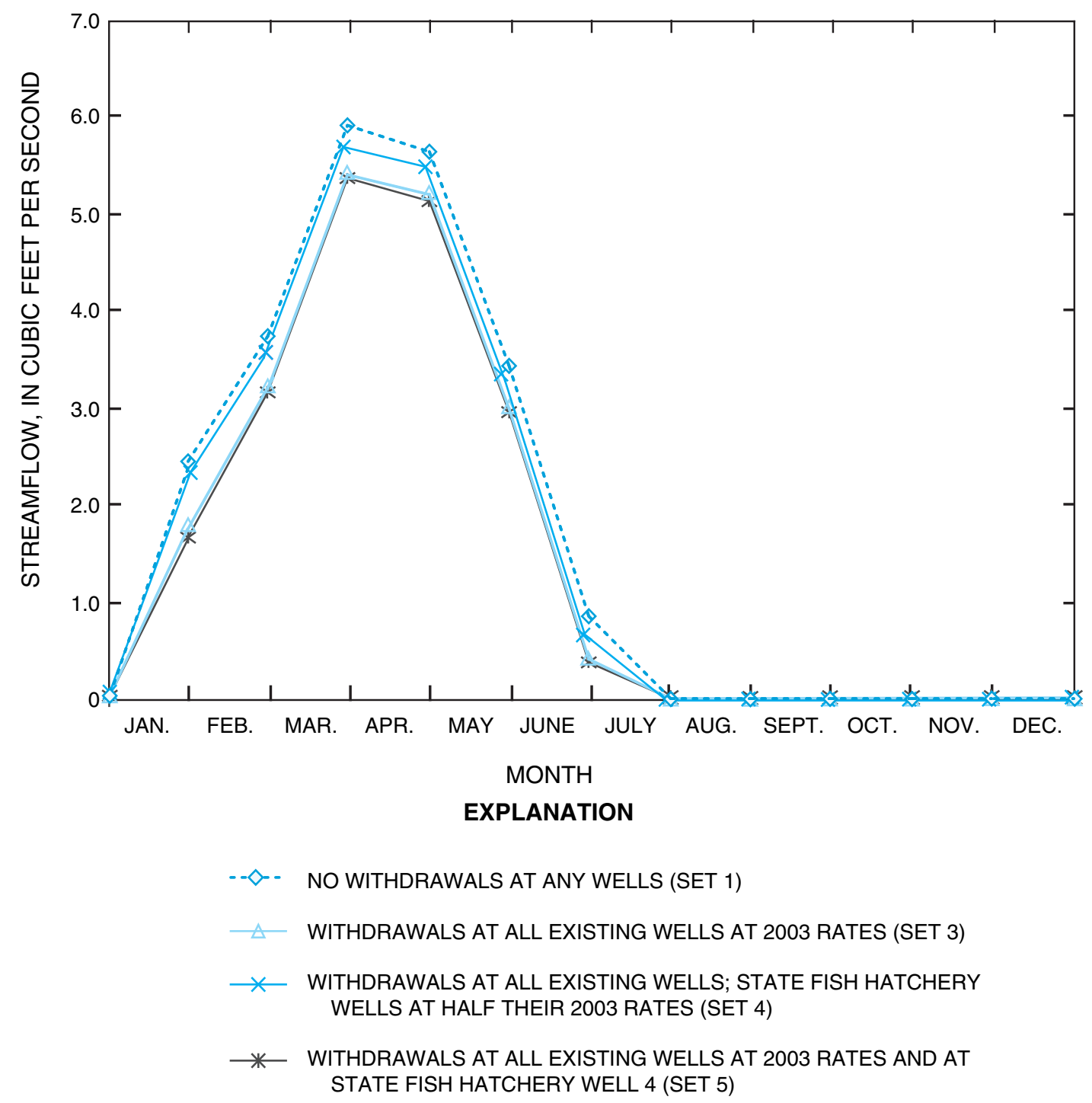

Figure 10. Model-calculated end-of-month streamflow in Queens Fort Brook at its outflow (site J).

numbers calculated by the models and model-convergence (or closure) errors resulting from the iterative process used in the numerical calculations. Total steady-state streamflow depletions at each of the outflow locations of the streams are $4.8 \mathrm{ft}^{3} / \mathrm{s}$ for the Hunt River, $1.8 \mathrm{ft}^{3} / \mathrm{s}$ for the Annaquatucket River, $0.5 \mathrm{ft}^{3} / \mathrm{s}$ for the Pettaquamscutt River, and less than $0.1 \mathrm{ft}^{3} / \mathrm{s}$ for the Cocumcossuc River. Streamflow depletions are largest in the Hunt River because ground-water withdrawal rates are largest in the Hunt River Basin. In the Annaquatucket River Basin, model-calculated streamflow depletions at the outflow location of the Annaquatucket River (site $P$, fig. 7) range from a minimum of $1.5 \mathrm{ft}^{3} / \mathrm{s}$ in January and February to a maximum of $2.6 \mathrm{ft}^{3} / \mathrm{s}$ in July. Model-calculated end-of-month streamflows in the Annaquatucket River at site $\mathrm{P}$ are shown in figure 11. Simulated streamflows in Queens Fort Brook and the Annaquatucket River above the
Hatchery Road stream site were unaffected by withdrawals at the production and industrial wells.

Simulation Set 3: Withdrawals at 2003 Rates at Existing Production and State Fish Hatchery Wells-In this set of model runs, withdrawals were simulated at all of the existing production, industrial, and fish-hatchery wells, at their 2003 pumping rates. Total long-term average (steady-state) withdrawal rates were $4.9 \mathrm{Mgal} / \mathrm{d}\left(7.6 \mathrm{ft}^{3} / \mathrm{s}\right)$ for the production wells and $1.5 \mathrm{Mgal} / \mathrm{d}\left(2.2 \mathrm{ft}^{3} / \mathrm{s}\right)$ at the hatchery wells. A constant discharge rate of $2.2 \mathrm{ft}^{3} / \mathrm{s}$ also was specified at the headwater of the Annaquatucket River just below the hatchery to represent discharge of water from the hatchery to the river.

Steady-state and transient model results indicate that the Annaquatucket River loses water to the underlying aquifer in the reach that extends from the hatchery to the Hatchery Road stream site. This was shown by simulated average annual 


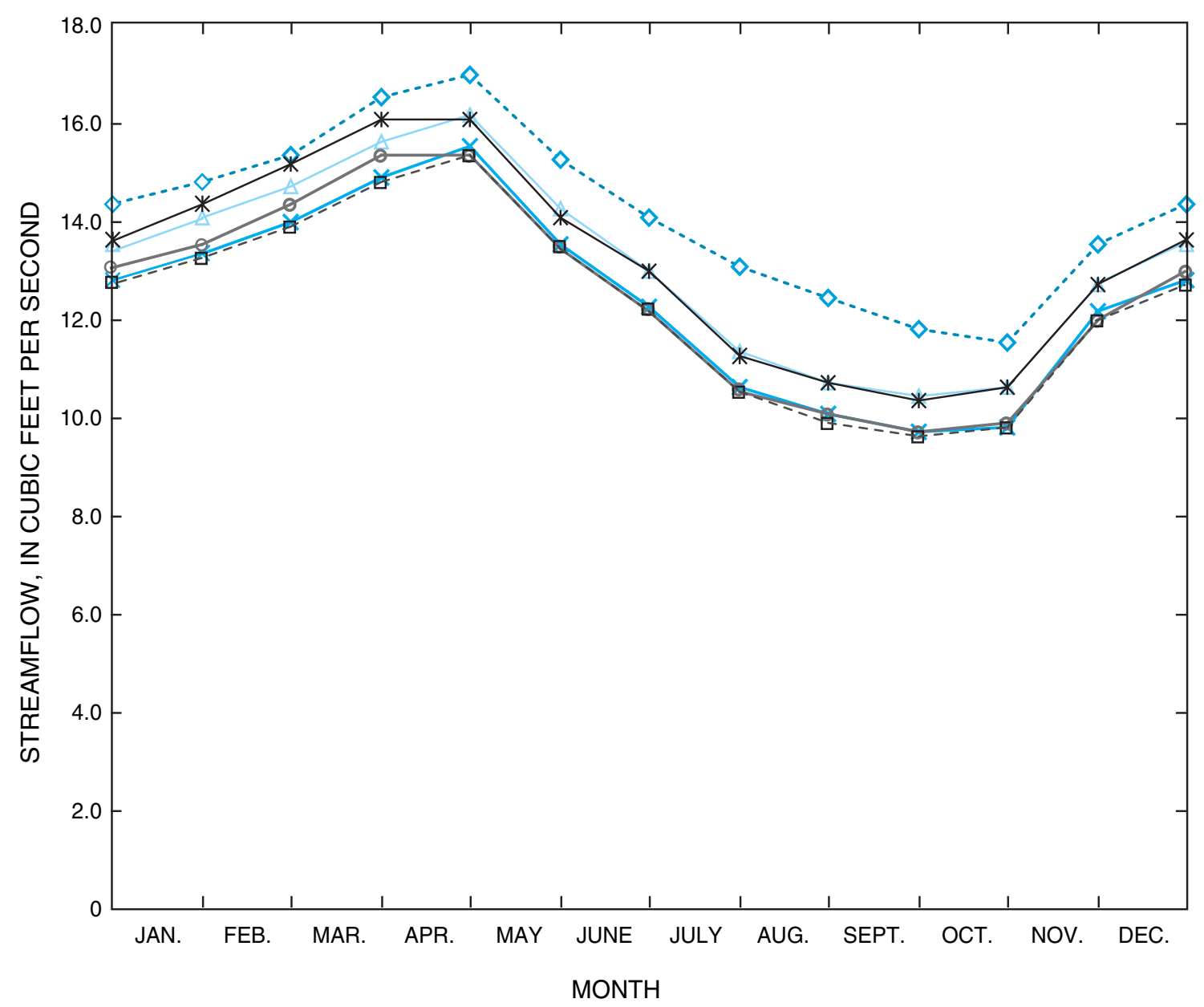

EXPLANATION

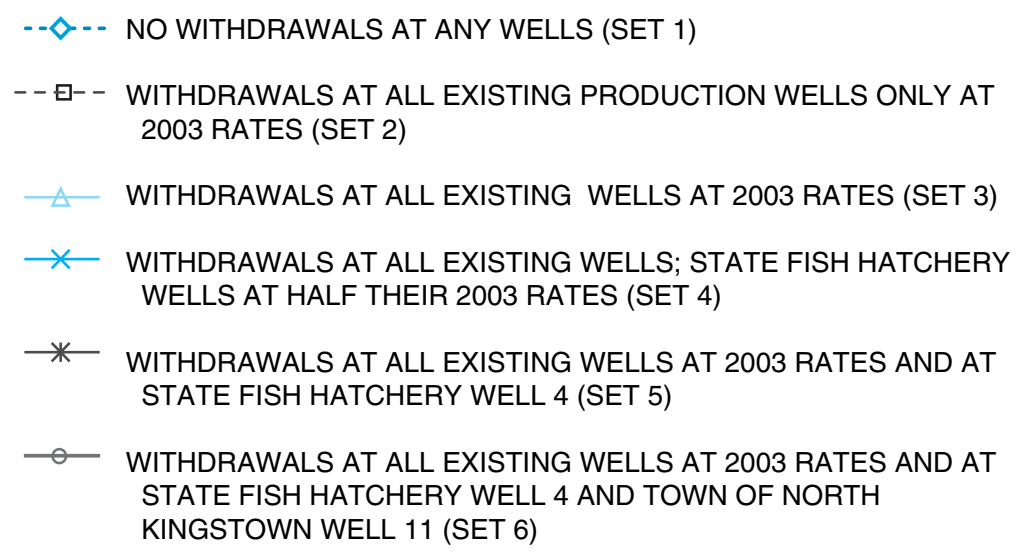

Figure 11. Model-calculated end-of-month streamflow in the Annaquatucket River at its outflow (site P). 
EXPLANATION

STRATIFIED DEPOSITS

TILL AND BEDROCK

BOUNDARY OF THE

STREAM-AQUIFER

SYSTEM

BOUNDARY OF ACTIVE AREA OF MODEL

GROUND-WATER

DRAINAGE BOUNDARY-

Where it differs from the surface-

water drainage basin boundary

GROUND-WATER AND

SURFACE-WATER DRAINAGE BOUNDARY
$100-$ MODEL-CALCULATED STEADY-
STATE WATER-TABLE CONTOUR-
Shows altitude of water table in feet above NGVD29. Contour interval is variable

NK2 WATER-SUPPLY WELL AND IDENTIFIER

Base from U.S. Geological Survey

East Greenwich, Slocum, Wickford, Crompton, 1:24,000, 1988-94 Rhode Island state plane projection
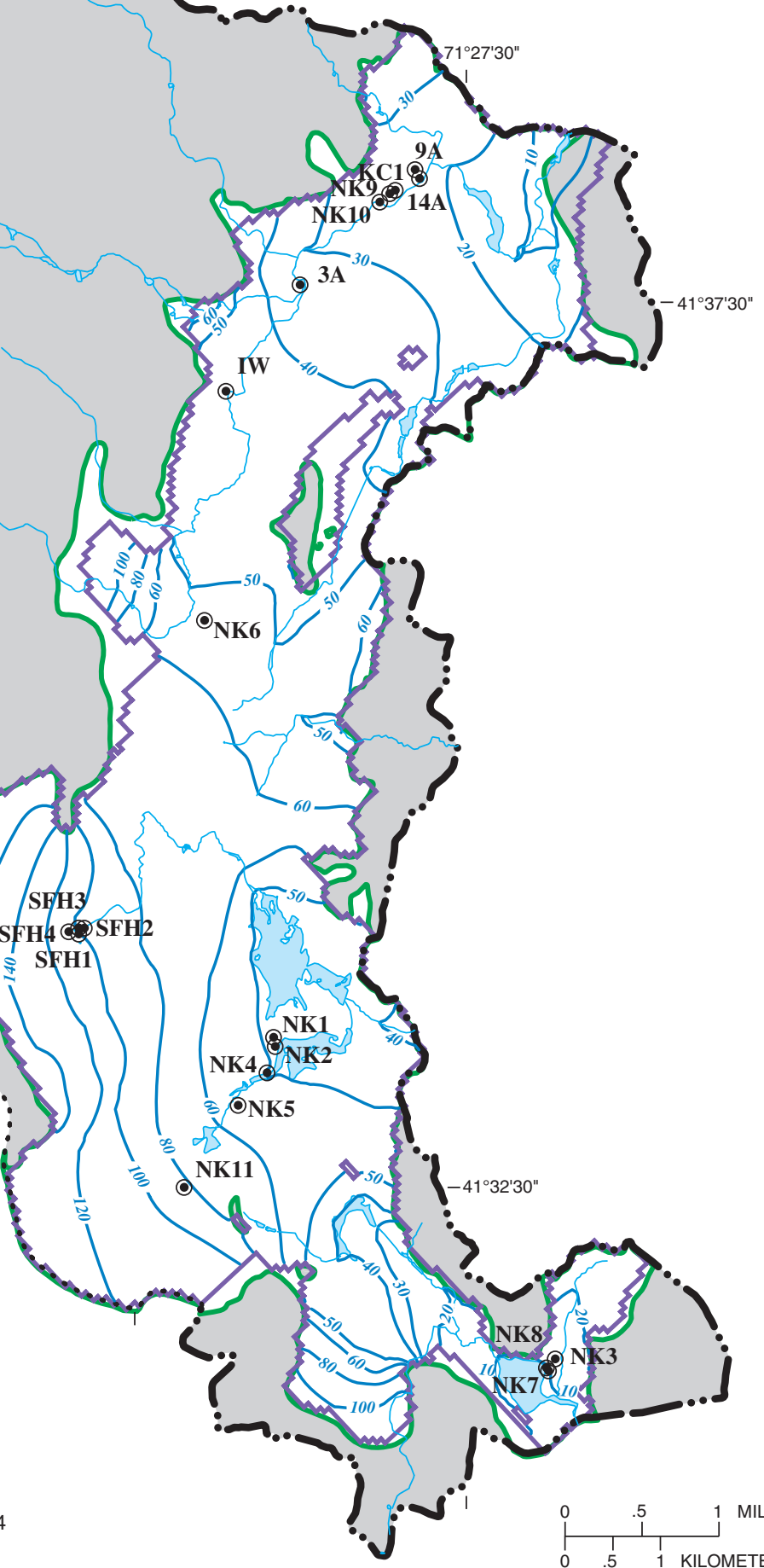
(table 8 ) and monthly streamflows that decrease by a constant rate of about $0.9 \mathrm{ft}^{3} / \mathrm{s}$ in this reach. As described above for the results of simulation set 1 , these model-calculated losing conditions are supported by streamflow measurements made during the original study, which showed a loss of streamflow in this reach during October 1996. The loss of streamflow in this reach may reflect an increase in the transmissivity of the aquifer east of the hatchery to Belleville Pond, which would result in a relative lowering of the altitude of the water table with respect to the altitude of the streambed and stream stage of the river. Although an increase in the transmissivity of the aquifer in this area cannot be supported directly with available data, an increase in the aquifer's transmissivity is suggested by the relatively flat gradient of the water table east of the hatchery to Belleville Pond (fig. 12).

Below the Hatchery Road site, the Annaquatucket River becomes gaining, and, as in the previous simulations, there is a substantial increase in the river's flow between the Hatchery Road site and the outflow location from the basin (table 8). Model results indicate that the flow at the river's outflow location is actually higher (by about $0.7 \mathrm{ft}^{3} / \mathrm{s}$ ) than for the previous simulation in which the hatchery wells were not pumping. The reason for this is that some of the water that is withdrawn by the hatchery wells is captured from Queens Fort Brook and then discharged to the Annaquatucket River at the hatchery; in the absence of withdrawals at the hatchery, this water would not have been available to the Annaquatucket River, and would have continued to flow to the Usquepaug-Queen River Basin. The amount of captured streamflow from Queens Fort Brook for steady-state conditions is $0.5 \mathrm{ft}^{3} / \mathrm{s}$, which is the difference between model-calculated streamflow in the brook for non-pumping conditions at the hatchery $\left(1.7 \mathrm{ft}^{3} / \mathrm{s}\right.$, simulation sets 1 and 2$)$ and pumping conditions $\left(1.2 \mathrm{ft}^{3} / \mathrm{s}\right.$, this simulation). The remaining increase in the rate of outflow from the Annaquatucket River (about $0.2 \mathrm{ft}^{3} / \mathrm{s}$ for steady-state conditions) is likely due to decreased rates of ground-water evapotranspiration in the Annaquatucket River Basin and to model error. The range in streamflow depletion calculated for Queens Fort Brook caused by pumping at the hatchery wells ranges from zero during August through December (when simulated baseflow in the river is zero) to $0.7 \mathrm{ft}^{3} / \mathrm{s}$ in January; model-calculated monthly streamflows in the brook are shown in figure 10 .
Note that if all of the water that is discharged from the hatchery to the Annaquatucket River had discharged from the basin at the Annaquatucket River outflow location, the river's flow would have been $14.6 \mathrm{ft}^{3} / \mathrm{s}$ for the long-term average conditions, which is determined by summing the flow of the river for the condition of no withdrawals at the hatchery $\left(12.4 \mathrm{ft}^{3} / \mathrm{s}\right.$; simulation set 2 , table 8$)$ and the total withdrawal rate from the hatchery wells $\left(2.2 \mathrm{ft}^{3} / \mathrm{s}\right)$. However, because the model-calculated flow rate for the river is only $13.1 \mathrm{ft}^{3} / \mathrm{s}$, it can be determined that about $1.5 \mathrm{ft}^{3} / \mathrm{s}$ of the water discharged by the wells consists of water that would have discharged to the Annaquatucket River in the absence of pumping at the hatchery. Overall, the sources of water to the hatchery wells for the steady-state simulation consist of about $0.5 \mathrm{ft}^{3} / \mathrm{s}$ reduced flow in Queens Fort Brook, $1.5 \mathrm{ft}^{3} / \mathrm{s}$ reduced flow in the Annaquatucket River, $0.1 \mathrm{ft}^{3} / \mathrm{s}$ reduced ground-water evapotranspiration, and about $0.1 \mathrm{ft}^{3} / \mathrm{s}$ undetermined sources (which include model-rounding error). Total streamflow depletion in the Annaquatucket River at its outflow location caused by withdrawals at all wells (both production and hatchery wells) is $3.3 \mathrm{ft}^{3} / \mathrm{s}$.

A map of the model-calculated water table for the 2003 annual average (steady-state) pumping conditions is shown in figure 12. Overall, the water-table contours are not substantially different from those shown for the 1996 withdrawal conditions (fig. 8). This results from the fact that although pumping rates are somewhat greater for the 2003 simulation conditions than those for the 1996 simulation conditions, the aquifer is highly transmissive in those areas of the Hunt and Annaquatucket River Basins where many of the production wells are located; therefore, changes in the altitude of the water table resulting from the increased withdrawals are generally small.

A map of water-table drawdowns (that is, ground-water level declines) for the 2003 average annual pumping rates is shown in figure 13. Drawdowns were calculated as the change in ground-water levels resulting from the condition of no ground-water pumping (simulation set 1) to that with the 2003 pumping rates. Drawdowns calculated for each cell of the model represent a single drawdown value over the entire 200ft by $200-f t$ area of each cell; drawdowns calculated at cells that include pumping wells do not represent the maximum drawdown that occurs at the location of withdrawal. 
Table 9. Model-calculated ground-water levels near Lafayette State Fish Hatchery for steady-state simulations.

[Water levels are for top layer of model. Water levels are in feet above NGVD29. Values in parentheses are drawdowns from simulation set 1, in feet. NK, town of North Kingstown; SFH, Lafayette State Fish Hatchery]

\begin{tabular}{|c|c|c|c|c|c|c|}
\hline \multirow[b]{2}{*}{ Location } & \multicolumn{6}{|c|}{ Simulation conditions } \\
\hline & $\begin{array}{c}\text { Set 1: No } \\
\text { withdrawals } \\
\text { at any wells }\end{array}$ & $\begin{array}{c}\text { Set } 2 \text { : } \\
\text { Withdrawals } \\
\text { at all existing } \\
\text { production } \\
\text { wells only at } \\
2003 \text { rates } \\
\end{array}$ & $\begin{array}{c}\text { Set } 3 \text { : } \\
\text { Withdrawals } \\
\text { at all existing } \\
\text { wells at } 2003 \\
\text { rates }\end{array}$ & $\begin{array}{c}\text { Set 4: } \\
\text { Withdrawals } \\
\text { at all existing } \\
\text { wells; SFH wells at } \\
\text { half their } 2003 \text { rates }\end{array}$ & $\begin{array}{c}\text { Set 5: } \\
\text { Withdrawals } \\
\text { at all existing } \\
\text { wells at } 2003 \\
\text { rates and at } \\
\text { well SFH4 } \\
\end{array}$ & $\begin{array}{c}\text { Set 6: } \\
\text { Withdrawals } \\
\text { at all existing } \\
\text { wells at } 2003 \text { rates } \\
\text { and at wells } \\
\text { SFH4 and NK11 }\end{array}$ \\
\hline Well SFH2 & 114.1 & $114.1(0.0)$ & $95.9(18.2)$ & $106.2(7.9)$ & $95.0(19.1)$ & $94.9(19.2)$ \\
\hline Well SFH3 & 115.8 & $115.8(0.0)$ & $96.5(19.3)$ & $107.2(8.6)$ & $95.6(20.2)$ & $95.5(20.3)$ \\
\hline Well SFH4 & 122.8 & $122.7(0.1)$ & $109.6(13.2)$ & $117.2(5.6)$ & $108.1(14.7)$ & $108.0(14.8)$ \\
\hline Wetland site A & 93.0 & $92.9(0.1)$ & $86.7 \quad(6.3)$ & $90.9(2.1)$ & $86.3(6.7)$ & $86.2(6.8)$ \\
\hline $\begin{array}{c}\text { Below wetland A } \\
\text { (stream site L) }\end{array}$ & 81.2 & $81.1(0.1)$ & $78.4 \quad(2.8)$ & $80.8(0.4)$ & $78.1 \quad(3.1)$ & 78.1 \\
\hline
\end{tabular}

The drawdown map indicates that ground-water level declines are generally less than $5 \mathrm{ft}$, with the exception of the area near the hatchery, where drawdowns are as much as $19.3 \mathrm{ft}$ at the cell containing well SFH3 (table 9; the locations of observation points shown in table 9 are given in fig. 14). Drawdowns are most likely greater in the hatchery area than in other parts of the aquifer because of the generally lower transmissivity of the aquifer near the hatchery wells than in other parts of the aquifer where withdrawals occur. For example, Rosenshein and others (1968, plate 2 and p. 11) report transmissivities of about 1,340 to $6,700 \mathrm{ft}^{2} / \mathrm{d}$ near the hatchery wells, compared to transmissivities that range from about 13,400 to 50,800 $\mathrm{ft}^{2} / \mathrm{d}$ along the Hunt and Annaquatucket River valleys where most of the production wells are located. The relatively large drawdowns at the fish-hatchery wells are consistent with water-level declines that have been measured at the hatchery wells during aquifer tests. For example, the drawdown at well $\mathrm{SFH} 2$ was $26.5 \mathrm{ft}$ at the end of a 48 -hour aquifer test during September 1994 in which well SFH2 was pumped at a rate of $400 \mathrm{gal} / \mathrm{min}$ for the first 24 hours and at a rate of $450 \mathrm{gal} / \mathrm{min}$ during the second 24 hours (R.E. Chapman Company, written communication to Rhode Island Department of Environmental Management, November 1994). Also, the drawdown at well SFH3 was $32.7 \mathrm{ft}$ at the end of a 166-hour aquifer test during June 1996 in which well SFH3 was pumped at a rate of 720 gal/min (R.E. Chapman Company, written commun., July 1996).
Model-calculated end-of-month ground-water levels at three locations within and near the fish hatchery (wells SFH3 and SFH4 and wetland site A) are shown in figure 15. The graphs indicate the declines in water levels that occur at each of the three locations from non-pumping conditions (simulation set 1 ) to pumping conditions (simulation set 3 ). The annual range of water-level fluctuations at the three points for non-pumping conditions is $1.9 \mathrm{ft}$ at wells SFH3 and SFH4 and $2.5 \mathrm{ft}$ at wetland site A; for pumping conditions, the ranges are 2.2 and $2.1 \mathrm{ft}$ at wells $\mathrm{SFH} 3$ and $\mathrm{SFH} 4$, respectively, and $2.4 \mathrm{ft}$ at wetland site A. Because simulated pumping rates at wells SFH1, SFH2, and SFH3 are constant throughout the year, water-level declines at each of the three locations are relatively constant throughout the year.

Hydrologic budgets were calculated for the aquifer within the three wetland areas near the hatchery by use of the Zonebudget computer program for MODFLOW (Harbaugh, 1990). These budgets provide information on how simulated flow conditions in the aquifer underlying the wetland areas change in response to pumping at the hatchery wells. Modelsimulated sources of water to the aquifer in the wetland areas include recharge to the water table underlying the wetlands, streamflow seepage from the Annaquatucket River, and ground-water inflow; model-simulated outflow components include evapotranspiration from the water table, discharge to the Annaquatucket River, and ground-water outflow. The areas for which budgets were calculated include only the top 
EXPLANATION

STRATIFIED DEPOSITS

TILL AND BEDROCK

BOUNDARY OF THE STREAM-AQUIFER SYSTEM

BOUNDARY OF ACTIVE AREA OF MODEL

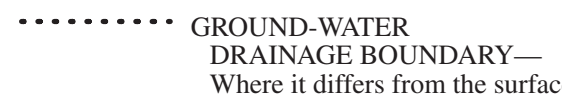

Where it differs from the surfacewater drainage basin boundary

\section{$\longrightarrow$ GROUND-WATER AND SURFACE-WATER DRAINAGE BOUNDARY}

\section{MODEL-CALCULATED STEADY-STATE
DRAWDOWN CONTOUR-Shows decrease
in altitude of water table in feet. Contour $\underset{\odot}{\text { NK2 }}$ WATER-SUPPLY WELL AND IDENTIFIER}

Base from U.S. Geological Survey

East Greenwich, Slocum, Wickford, Crompton, 1:24,000, 1988-94

Rhode Island state plane projection

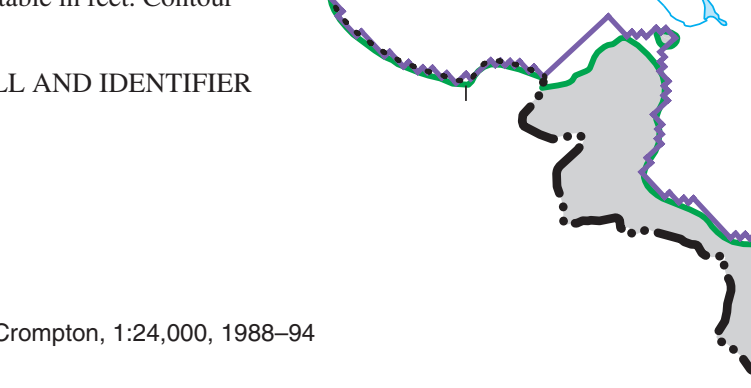




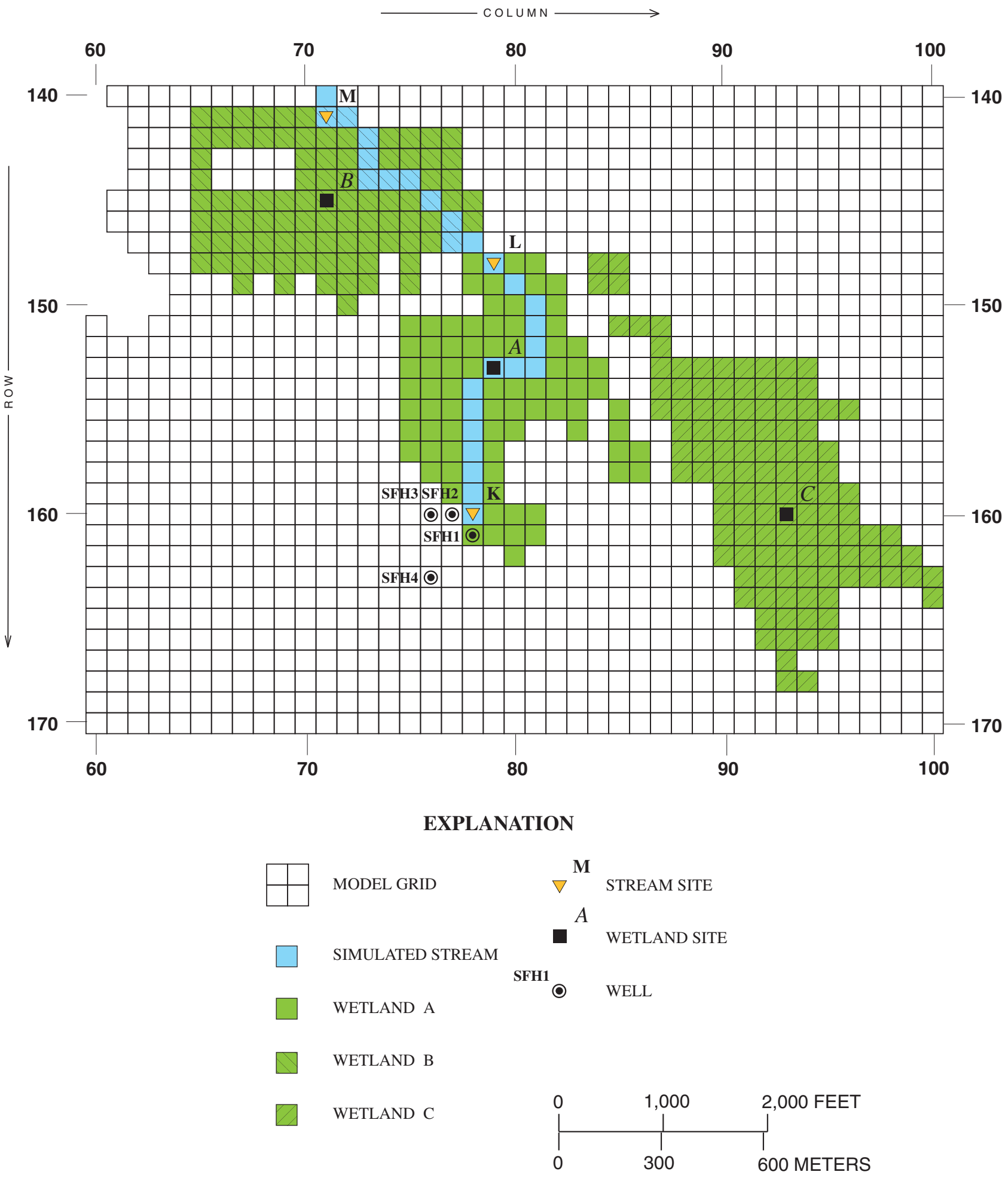

Figure 14. Model-grid locations of wetlands near Lafayette State Fish Hatchery, Rhode Island. Simulated stream is the Annaquatucket River. 

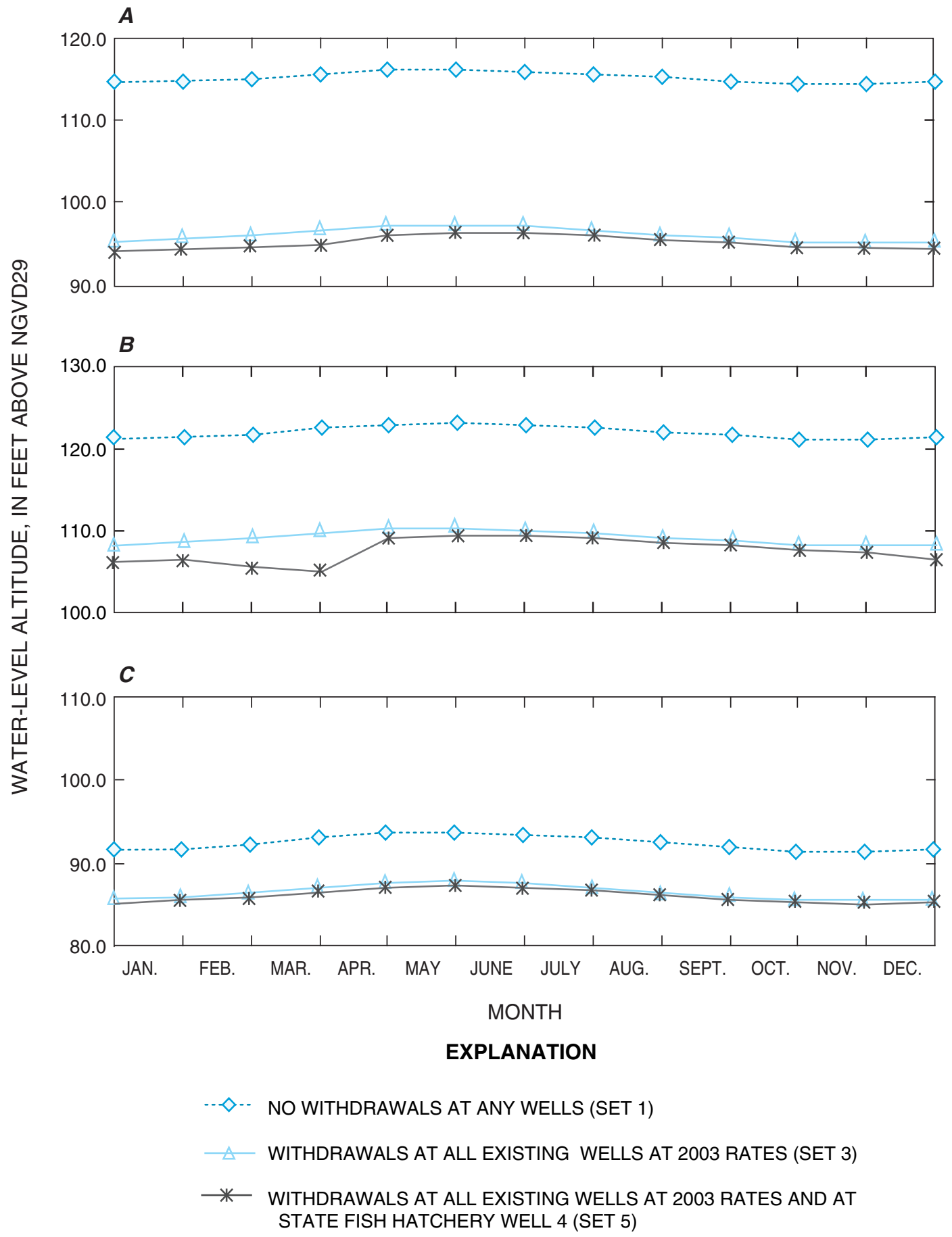

Figure 15. Model-calculated end-of-month ground-water levels at $(A)$ State Fish Hatchery well 3, $(B)$ State Fish Hatchery well 4, and $(C)$ wetland site $A$. 
Table 10. Model-calculated steady-state flows to and from the aquifer in wetland areas near Lafayette State Fish Hatchery.

[All values are in cubic feet per second. Total inflow may not equal total outflow for each simulation because of rounding errors; SFH, Lafayette State Fish Hatchery]

\begin{tabular}{|c|c|c|c|}
\hline \multirow{2}{*}{ Flow } & \multicolumn{3}{|c|}{ Simulation Set 1: No withdrawals at any wells } \\
\hline & Wetland A & Wetland B & Wetland C \\
\hline \multicolumn{4}{|c|}{ Inflow } \\
\hline Recharge & 0.3 & 0.3 & 0.4 \\
\hline Streamflow seepage & .1 & .0 & .0 \\
\hline Ground-water inflow & 1.9 & 1.6 & 1.4 \\
\hline Total inflow & 2.3 & 1.9 & 1.8 \\
\hline \multicolumn{4}{|c|}{ Outflow } \\
\hline Evapotranspiration & 0.0 & 0.0 & 0.1 \\
\hline Streamflow discharge & .1 & .0 & .0 \\
\hline Ground-water outflow & 2.1 & 1.9 & 1.7 \\
\hline Total outflow & 2.2 & 1.9 & 1.8 \\
\hline \multirow{2}{*}{ Flow } & \multicolumn{3}{|c|}{ Simulation Set 3: Withdrawals at all existing wells at 2003 rates } \\
\hline & Wetland A & Wetland B & Wetland C \\
\hline \multicolumn{4}{|c|}{ Inflow } \\
\hline Recharge & 0.3 & 0.3 & 0.4 \\
\hline Streamflow seepage & .3 & .2 & .0 \\
\hline Ground-water inflow & 1.4 & 1.4 & 1.2 \\
\hline Total inflow & 2.0 & 1.9 & 1.6 \\
\hline \multicolumn{4}{|c|}{ Outflow } \\
\hline Evapotranspiration & 0.0 & 0.0 & 0.0 \\
\hline Streamflow discharge & .0 & .0 & .0 \\
\hline Ground-water outflow & 2.0 & 1.8 & 1.5 \\
\hline Total outflow & 2.0 & 1.8 & 1.5 \\
\hline
\end{tabular}

\begin{tabular}{|c|c|c|c|}
\hline \multirow{2}{*}{ Flow } & \multicolumn{3}{|c|}{ Simulation Set 4: Withdrawals at all existing wells; SFH wells at half their 2003 rates } \\
\hline & Wetland A & Wetland B & Wetland C \\
\hline \multicolumn{4}{|c|}{ Inflow } \\
\hline Recharge & 0.3 & 0.3 & 0.4 \\
\hline Streamflow seepage & .3 & .2 & .0 \\
\hline Ground-water inflow & 1.6 & 1.4 & 1.3 \\
\hline Total inflow & 2.2 & 1.9 & 1.7 \\
\hline \multicolumn{4}{|c|}{ Outflow } \\
\hline Evapotranspiration & 0.0 & 0.0 & 0.0 \\
\hline Streamflow discharge & .0 & .0 & .0 \\
\hline Ground-water outflow & 2.1 & 1.9 & 1.6 \\
\hline Total outflow & 2.1 & 1.9 & 1.6 \\
\hline \multirow{2}{*}{ Flow } & \multicolumn{3}{|c|}{ Simulation Set 5: Withdrawals at all existing wells at 2003 rates and at well SFH4 } \\
\hline & Wetland A & Wetland B & Wetland C \\
\hline \multicolumn{4}{|c|}{ Inflow } \\
\hline Recharge & 0.3 & 0.3 & 0.4 \\
\hline Streamflow seepage & .3 & .2 & .0 \\
\hline Ground-water inflow & 1.4 & 1.4 & 1.1 \\
\hline Total inflow & 2.0 & 1.9 & 1.5 \\
\hline \multicolumn{4}{|c|}{ Outflow } \\
\hline Evapotranspiration & 0.0 & 0.0 & 0.0 \\
\hline Streamflow discharge & .0 & .0 & .0 \\
\hline Ground-water outflow & 2.0 & 1.8 & 1.5 \\
\hline Total outflow & 2.0 & 1.8 & 1.5 \\
\hline
\end{tabular}


layer of the model (layer 1), although ground-water inflows and outflows to and from these areas are from both layers 1 and 2 of the model. It is important to note that these areas of the aquifer were not simulated any differently than other areas of the model; they are simply areas of the aquifer that are overlain by wetlands, from which ground-water discharge can take place by evapotranspiration from the water table and by discharge to the Annaquatucket River, and to which ground-water recharge and streamflow seepage from the Annaquatucket River can take place.

Steady-state model results indicate that for nonpumping conditions (simulation set 1 ), total steady-state inflows to these aquifer areas are $2.3 \mathrm{ft}^{3} / \mathrm{s}$ for wetland $\mathrm{A}, 1.9$ $\mathrm{ft}^{3} / \mathrm{s}$ for wetland $\mathrm{B}$, and $1.8 \mathrm{ft}^{3} / \mathrm{s}$ for wetland $\mathrm{C}$; in each case, the majority of water that flows to and from these areas is from ground-water inflows and outflows (table 10). With pumping at the three hatchery wells at 2003 rates (this simulation), the average rate of reduction in ground-water inflow to the wetlands is $0.5 \mathrm{ft}^{3} / \mathrm{s}$ for wetland $\mathrm{A}, 0.2 \mathrm{ft}^{3} / \mathrm{s}$ for wetland $\mathrm{B}$, and $0.2 \mathrm{ft}^{3} / \mathrm{s}$ for wetland $\mathrm{C}$ (table 10). However, because of losing conditions along the Annaquatucket River, there is actually an increase in the amounts of streamflow that seep into wetlands $\mathrm{A}$ and $\mathrm{B}$ for the pumping and hatchery-discharge conditions simulated in this model run; as a consequence, there is an overall reduction in flow to wetlands A and B caused by pumping at the hatchery wells of only 0.3 and $0.0 \mathrm{ft}^{3} / \mathrm{s}$, respectively.

Model-calculated rates of ground-water evapotranspiration from the aquifer in the wetland areas are very small for both pumping and non-pumping conditions (less than $0.1 \mathrm{ft}^{3} / \mathrm{s}$ in all cases). These low rates of ground-water evapotranspiration result from the fact that model-calculated ground-water levels in the wetland areas are generally below the specified 4-ft maximum depth below land surface at which groundwater evapotranspiration occurs. Unfortunately, there are few ground-water-level measurements in the wetland areas to support or refute these simulation results. Data provided by R.E. Chapman Company to RIDEM (written commun., December 5, 1995) indicate that the depth to water at an observation well in the southern part of wetland A near wells SFH1 and SFH2 (test well 2), was about $4.6 \mathrm{ft}$ below land surface in December 1995; ground-water-level data from a second well (test well 6), which also appears to be within or just west of wetland $A$, indicates a depth to water of $6.0 \mathrm{ft}$ below land surface in December 1995. Both of these measured water levels are below the 4-ft maximum depth below landsurface criterion at which ground-water evapotranspiration is assumed to cease.
Hydrologic budgets calculated for the aquifer in the wetland areas using the transient model show pumping effects that are similar to those calculated by the steady-state model; that is, most changes that occur in the budgets consist of reductions in the amounts of ground-water inflow and outflow to and from the aquifer in the wetlands.

Contributing areas delineated for the wells are shown in figure 16. Contributing areas for some of the wells are grouped into single areas. This was done where wells are close together and their contributing areas were difficult to differentiate well-by-well because of the presence of weak internal sinks. Weak internal sinks are model cells that contain simulated streams, wells, or areas of evapotranspiration in which the amount of water removed by the internal sink is less than the total amount of water that flows into the cell. Weak sinks cause some ambiguities in the delineation of contributing areas because it cannot be determined whether a particle that enters a cell with a weak sink should be removed by the sink or should continue through the flow system (Pollock, 1994).

Contributing areas delineated for each well are specific to the simulated pumping rates at each well, as well as pumping rates and other stresses simulated at other locations in the model. Several of the contributing areas extend to the boundary of the active area of the model, which implies that some of the water captured by the wells is derived from the upland areas of till and bedrock. Contributing areas to wells 9A, 14A, $\mathrm{KC}$, NK9, and 3A are very similar to those delineated in the original study because the 2003 pumping rates at the wells did not differ substantially from the 1996 pumping conditions simulated in the original study. The contributing area to well NK6 is larger than that delineated in the original study because the 2003 pumping rate at the well was more than twice that during 1996. Contributing areas to wells SFH1, $\mathrm{SFH} 2$, and SFH3 are larger than those delineated for the 1996 pumping rates. Moreover, contributing areas delineated for the hatchery wells overlie the wellheads, which they did not do in the original study. This is most likely because of the higher 2003 pumping rates at the wells and the changes that were made to the simulated aquifer conditions near the hatchery that resulted in less saturated thickness of the aquifer at the wells. Contributing areas to wells NK1, NK2, NK4, and NK5 are different from those determined in the original study because of changes made to the lateral extent of the active area of the model in the area south of the hatchery and west of Belleville Pond. Also, the total 2003 pumping rate at wells NK1, NK2, and NK4 was about twice that at the wells in 1996, whereas the rate at well NK5 was almost half that in 1996. As seen on figure 16, the contributing area to well NK5 


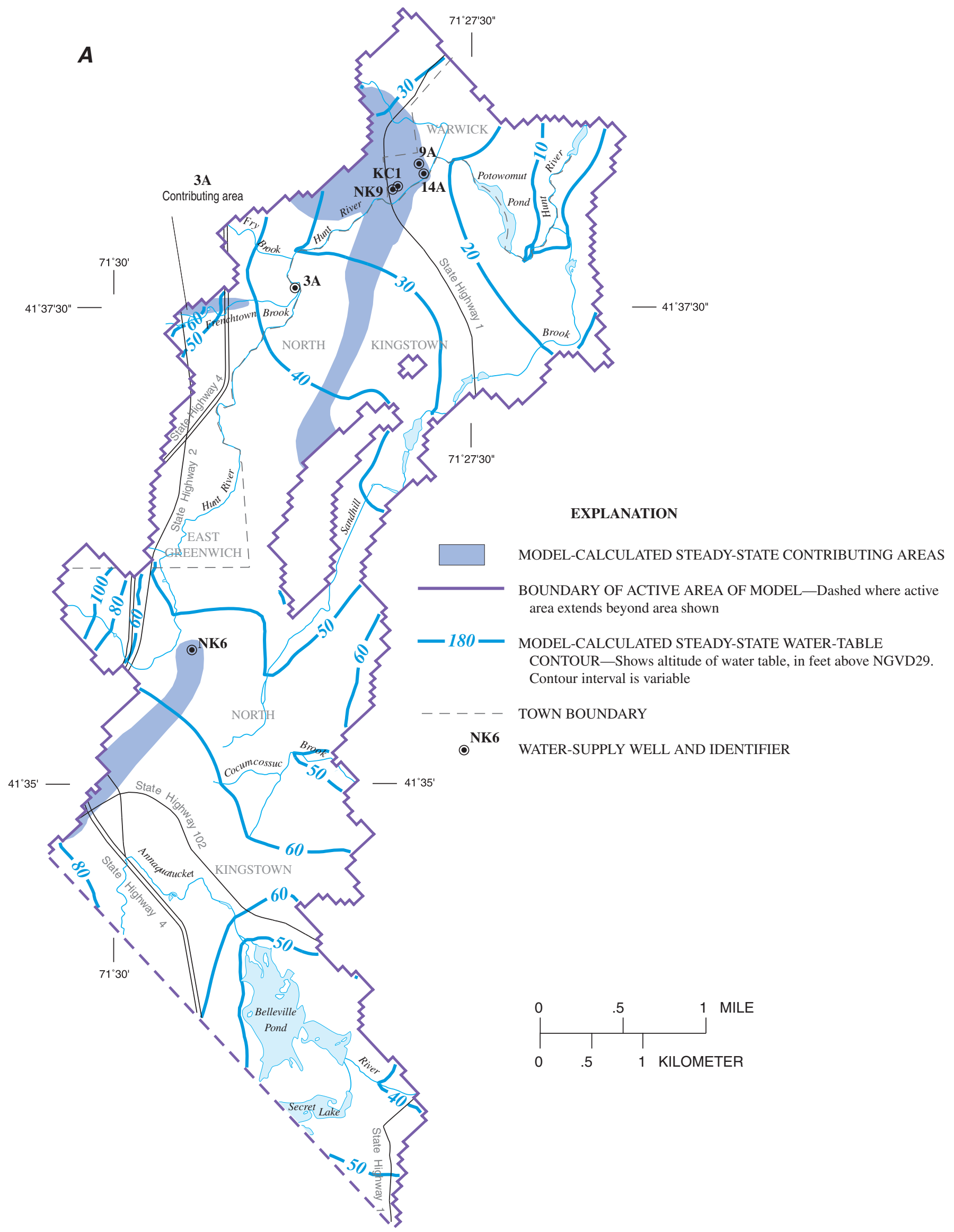

Figure 16. Model-calculated steady-state contributing areas to water-supply wells in $(A)$ the Hunt River Basin and 


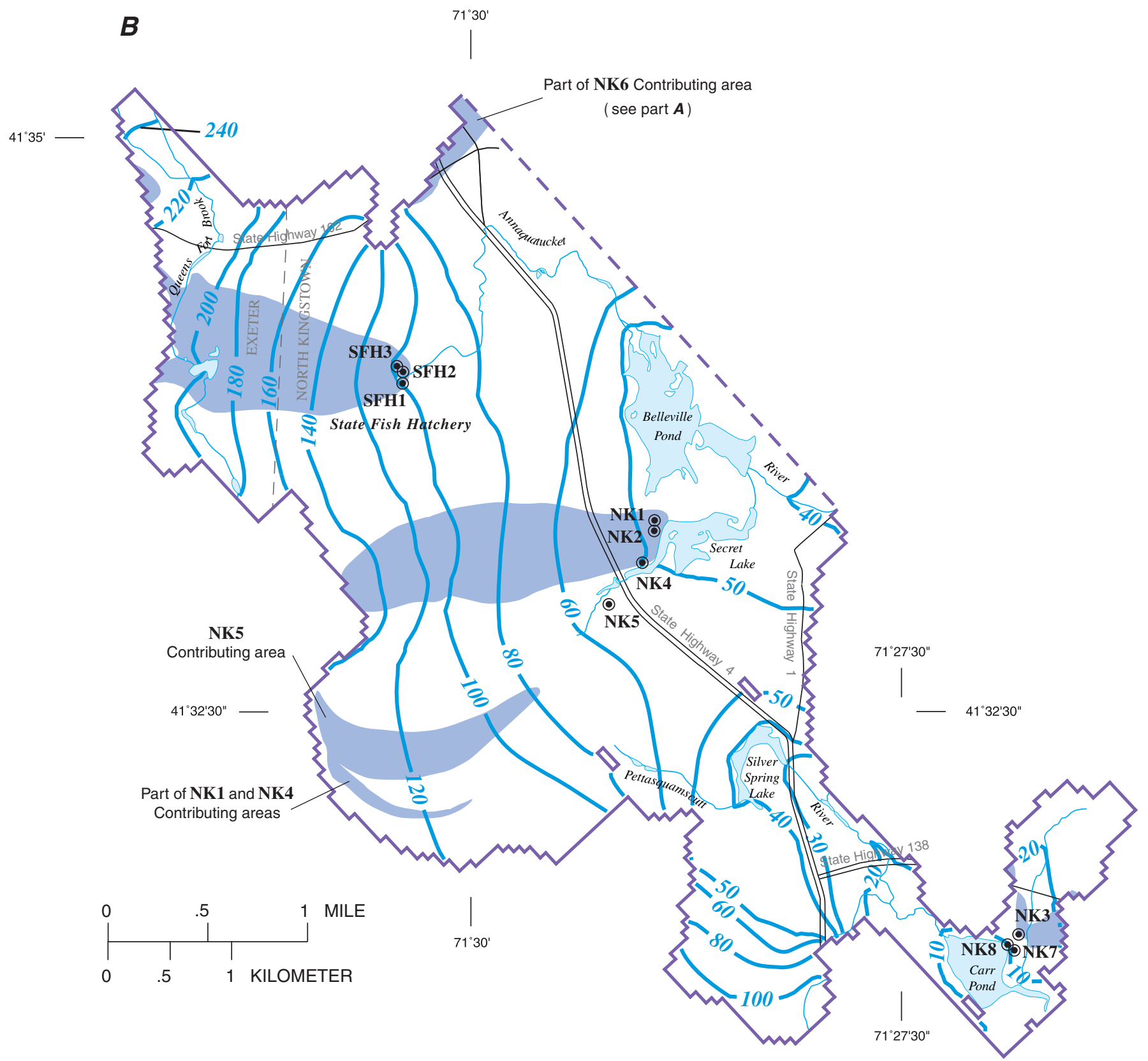

Base from U.S. Geological Survey

East Greenwich, Slocum, Wickford, Crompton, 1:24,000, 1988-94

Rhode Island state plane projection 
does not overlie the wellhead, which is consistent with the results of the original study.

Simulation Set 4: Withdrawals at Existing Production Wells at 2003 Rates and State Fish Hatchery Wells at Half Their 2003 Rates - In this set of model runs, simulated withdrawals at the fish-hatchery wells were reduced by half their 2003 rates (to $1.1 \mathrm{ft}^{3} / \mathrm{s}$ ), while withdrawals at all production wells were maintained at their 2003 rates. This simulation set was done to evaluate the effects of lower pumping rates at the hatchery on the hydrologic system. The simulated reductions in withdrawals resulted in an increase in streamflow in Queens Fort Brook at its outflow location from the basin to $1.5 \mathrm{ft}^{3} / \mathrm{s}$ for steady-state conditions (table 8); streamflows calculated for transient conditions also are higher (fig. 10). Flow rates along the Annaquatucket River, however, actually decrease from the previous set of simulations because the amount of water that is discharged to the river below the hatchery is reduced from 2.2 to $1.1 \mathrm{ft}^{3} / \mathrm{s}$. The sources of water to the hatchery wells for the steady-state simulation consist of about $0.2 \mathrm{ft}^{3} / \mathrm{s}$ reduced flow in Queens Fort Brook and about $1.1 \mathrm{ft}^{3} / \mathrm{s}$ reduced flow in the Annaquatucket River; these values contain some model error, including rounding error.

Drawdowns in the altitude of the water table near the hatchery are substantially less for these withdrawal conditions than for the 2003 withdrawal rates (table 9 and fig. 17). The maximum ground-water-level decline, which is at well SFH3, is $8.6 \mathrm{ft}$, or about $11 \mathrm{ft}$ less than that calculated for the 2003 withdrawal rates. The total reductions in flow to the aquifer in the wetland areas resulting from these withdrawal conditions at the hatchery wells (compared to the condition of no withdrawals at the wells) are about $0.1 \mathrm{ft}^{3} / \mathrm{s}$ to each of wetlands $\mathrm{A}$ and $\mathrm{C}$ and less than $0.1 \mathrm{ft}^{3} / \mathrm{s}$ to wetland $\mathrm{B}$ (table 10).

Simulation Set 5: Withdrawals at 2003 Rates at Existing Production and State Fish Hatchery Wells and Additional Withdrawals at the Proposed State Fish Hatchery Well_-In this set of model runs, pumping at proposed well SFH4 was simulated in addition to withdrawals at 2003 rates at all existing wells in the basin. Monthly pumping rates specified at well SFH4 are given in table 1, and range from a minimum of zero from April through September to $260 \mathrm{gal} / \mathrm{min}$ $(0.4 \mathrm{Mgal} / \mathrm{d})$ in March. Because the well is anticipated to be used during only 6 months of the year, the average annual pumping rate of the well is only $0.13 \mathrm{ft}^{3} / \mathrm{s}(0.08 \mathrm{Mgal} / \mathrm{d})$, which increases the total average annual withdrawal rate at the hatchery (and associated discharge to the headwater of the Annaquatucket River) from approximately $2.24 \mathrm{ft}^{3} / \mathrm{s}$ in 2003 to $2.37 \mathrm{ft}^{3} / \mathrm{s}$ in the future, or by about 5 percent. The increased withdrawals at the hatchery reduce the average annual flow in Queens Fort Brook at its outflow from the basin by less than $0.05 \mathrm{ft}^{3} / \mathrm{s}$ from its simulated 2003 rate (set 3 ) and in the Annaquatucket River at its outflow from the basin by about $0.1 \mathrm{ft}^{3} / \mathrm{s}$ (which includes an undetermined amount of model error).

Average annual ground-water-level declines in the aquifer resulting from the increased withdrawal in the hatchery area (table 9; fig. 18) are not substantially greater than those for the 2003 average annual pumping conditions. For example, an increased ground-water-level decline of about $1.5 \mathrm{ft}$ is calculated at the proposed supply well (SFH4) and less than $1 \mathrm{ft}$ at the three existing wells. Ground-water levels calculated with the transient model show the effects of increased withdrawals at well SFH4, particularly at well SFH4 during December through March (fig. 15B). Model-calculated changes in flow rates to the three wetland areas for average annual conditions for pumping at well SFH4 also are not substantially different from those calculated for 2003 pumping rates (table 10). Decreases in total flows of less than $0.05 \mathrm{ft}^{3} / \mathrm{s}$ from the 2003 rates were calculated for each of the three wetlands; these reductions in flow are less than the accuracy of the values calculated by the model.

Simulation Set 6: Withdrawals at 2003 Rates at Existing Production and State Fish Hatchery Wells and Additional Withdrawals at the Proposed State Fish Hatchery Well and New Town of North Kingstown Well_-All aspects of this last set of model simulations are the same as for the previous set, with the addition of pumping at new well NK11 in the Annaquatucket River Basin at a rate of $1.0 \mathrm{Mgal} / \mathrm{d}$ $\left(1.5 \mathrm{ft}^{3} / \mathrm{s}\right)$ for both steady-state and transient simulation conditions. For this withdrawal condition, steady-state flow in the Annaquatucket and Pettaquamscutt Rivers at their outflow locations are reduced by $0.8 \mathrm{ft}^{3} / \mathrm{s}$ and $0.2 \mathrm{ft}^{3} / \mathrm{s}$, respectively, over the previous simulation (table 8 ). The steady-state sources of water to the new well calculated on the basis of model results consist of this total of $1.0 \mathrm{ft}^{3} / \mathrm{s}$ reduced streamflow in the Annaquatucket and Pettaquamscutt Rivers, $0.5 \mathrm{ft}^{3} / \mathrm{s}$ induced ground-water flow into the Annaquatucket River Basin across the ground-water divide that separates the Annaquatucket and Chipuxet River Basins, and about $0.1 \mathrm{ft}^{3} / \mathrm{s}$ reduced evapotranspiration from the water table. Results of the transient model indicate that the increased flow rate across the Annaquatucket/Chipuxet ground-water divide is constant at a rate of $0.5 \mathrm{ft}^{3} / \mathrm{s}$ throughout the year; this constant flow rate likely results from the constant withdrawal rate of $1.0 \mathrm{Mgal} / \mathrm{d}$ simulated at the well throughout the year.

Steady-state water-table and drawdown contours in the aquifer calculated for these pumping conditions are shown in figures 19 and 20, respectively. Model-calculated drawdowns near NK11 are as much as $18 \mathrm{ft}$. These relatively large drawdowns near the well are consistent with those measured during the 2005 aquifer test at the site by Fay, Spofford, and Thorndike (2005). The pumping rate at well NK11 during that test was $750 \mathrm{gal} / \mathrm{min}(1.08 \mathrm{Mgal} / \mathrm{d})$. Drawdown at the well at the end of the 72-hour test was $73 \mathrm{ft}$; drawdowns at the end of the test at observation wells located $10 \mathrm{ft}, 70 \mathrm{ft}$, and $350 \mathrm{ft}$ from the pumped well were about $31 \mathrm{ft}, 5 \mathrm{ft}$, and $2 \mathrm{ft}$, respectively (Fay, Spofford, and Thorndike, 2005). The relatively large drawdowns at the site reflect the relatively low transmissivity of the aquifer at the site as calculated by Fay, Spofford, and Thorndike (2005) and described earlier in this report. Drawdowns calculated by the model may not be completely accurate west of the well toward the simulated Annaquatucket/ Chipuxet ground-water drainage divide. This divide is an area 
EXPLANATION

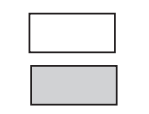

STRATIFIED DEPOSITS

TILL AND BEDROCK

BOUNDARY OF THE STREAM-AQUIFER SYSTEM

BOUNDARY OF ACTIVE AREA OF MODEL

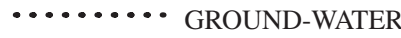

DRAINAGE BOUNDARY-

Where it differs from the surfacewater drainage basin boundary

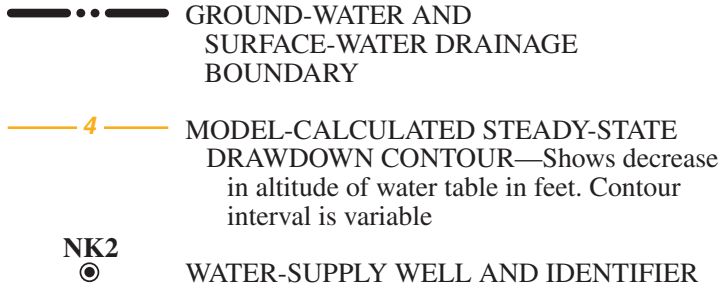

- WATER-SUPPLY WELL AND IDENTIFIER

Base from U.S. Geological Survey

East Greenwich, Slocum, Wickford, Crompton, 1:24,000, 1988-94

Rhode Island state plane projection

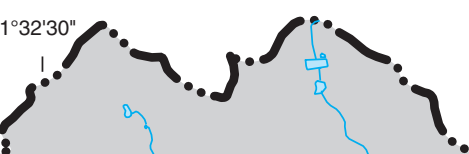


EXPLANATION

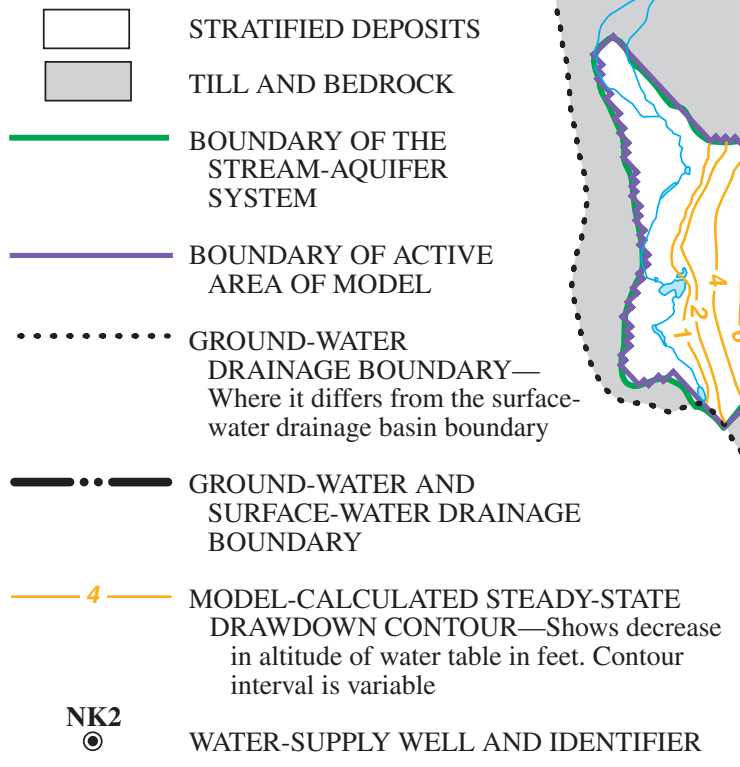

Base from U.S. Geological Survey

East Greenwich, Slocum, Wickford, Crompton, 1:24,000, 1988-94

Rhode Island state plane projection

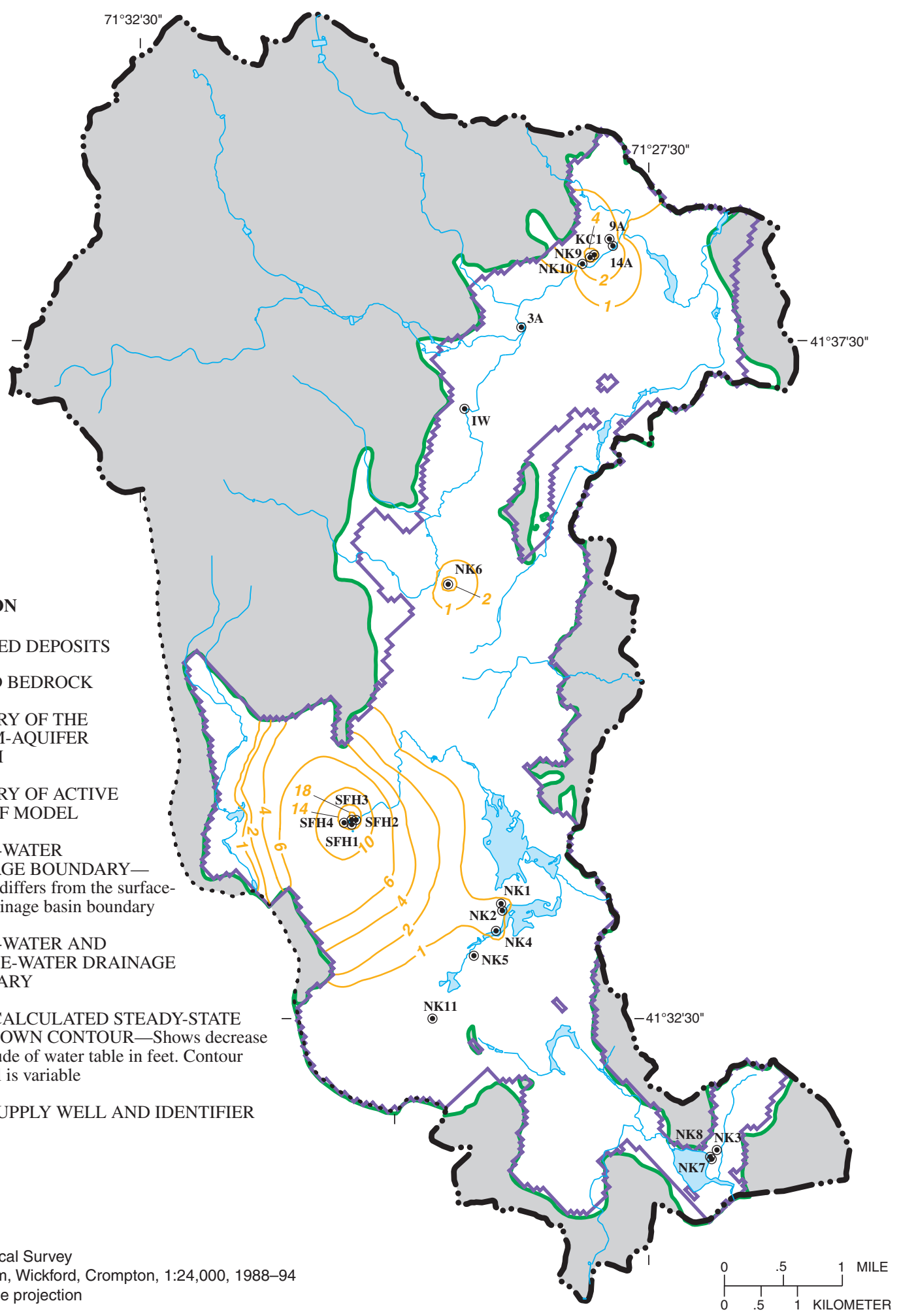

Figure 18. Model-calculated steady-state drawdowns for simulation set 5 (with State Fish Hatchery well 4 pumping), Hunt-Annaquatucket-Pettaquamscutt stream-aquifer system, Rhode Island. 
EXPLANATION

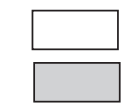

STRATIFIED DEPOSITS

TILL AND BEDROCK

BOUNDARY OF THE STREAM-AQUIFER SYSTEM

BOUNDARY OF ACTIVE AREA OF MODEL

\section{$\cdots \cdots \cdots \cdot$ GROUND-WATER \\ DRAINAGE BOUNDARY- \\ Where it differs from the surface-} water drainage basin boundary

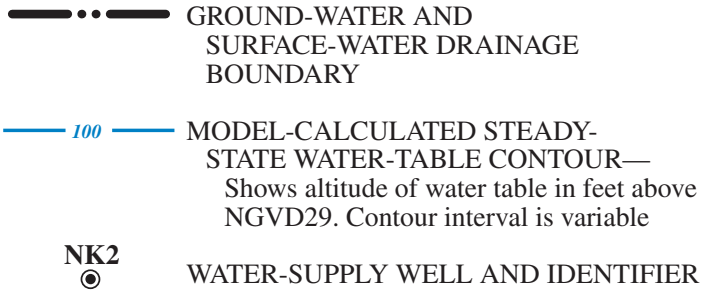

Base from U.S. Geological Survey

East Greenwich, Slocum, Wickford, Crompton, 1:24,000, 1988-94

Rhode Island state plane projection

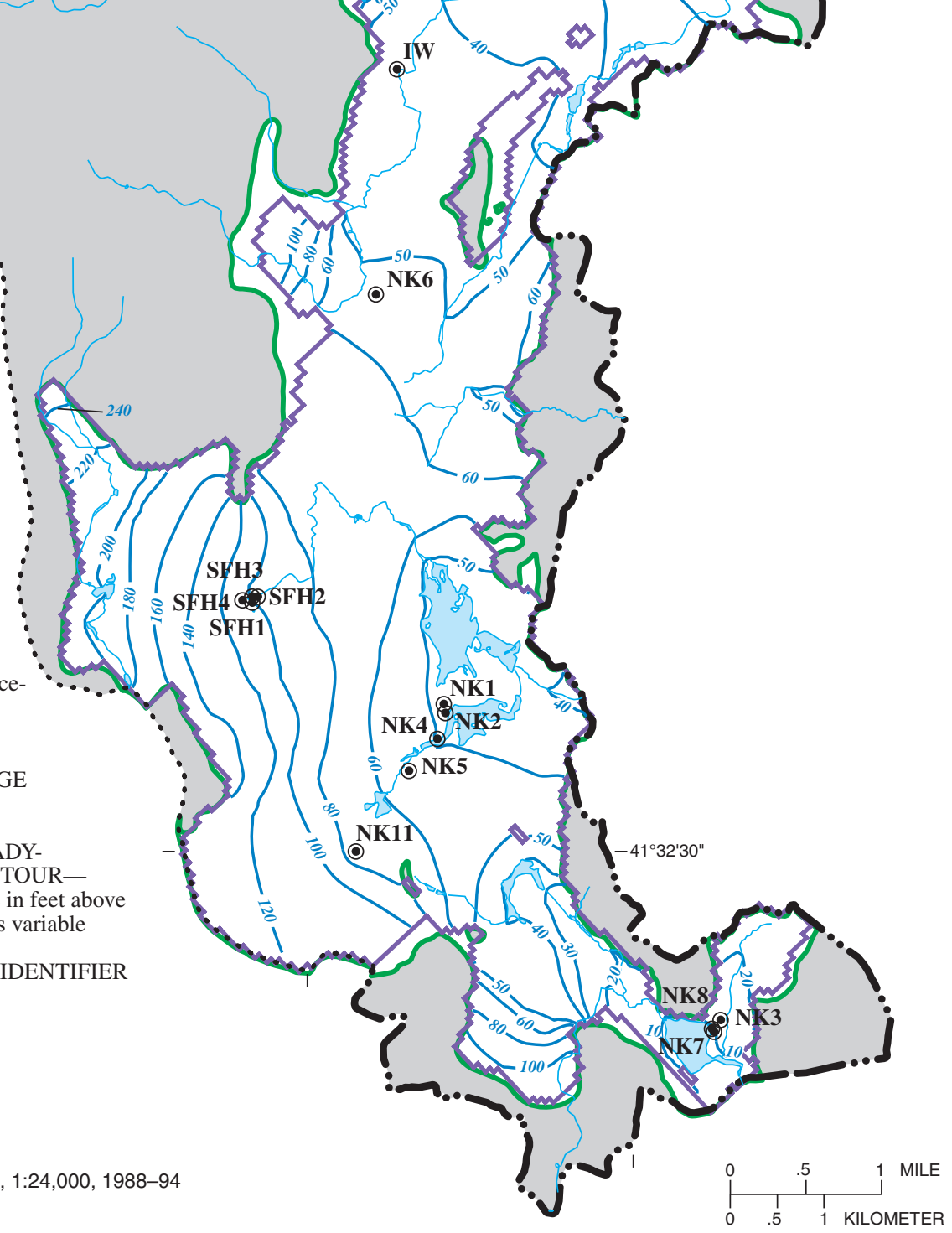

Figure 19. Model-calculated steady-state water table for simulation set 6 (with State Fish Hatchery well 4 and the town of North Kingstown well 11 pumping), Hunt-Annaquatucket-Pettaquamscutt stream-aquifer system, Rhode Island. 
EXPLANATION

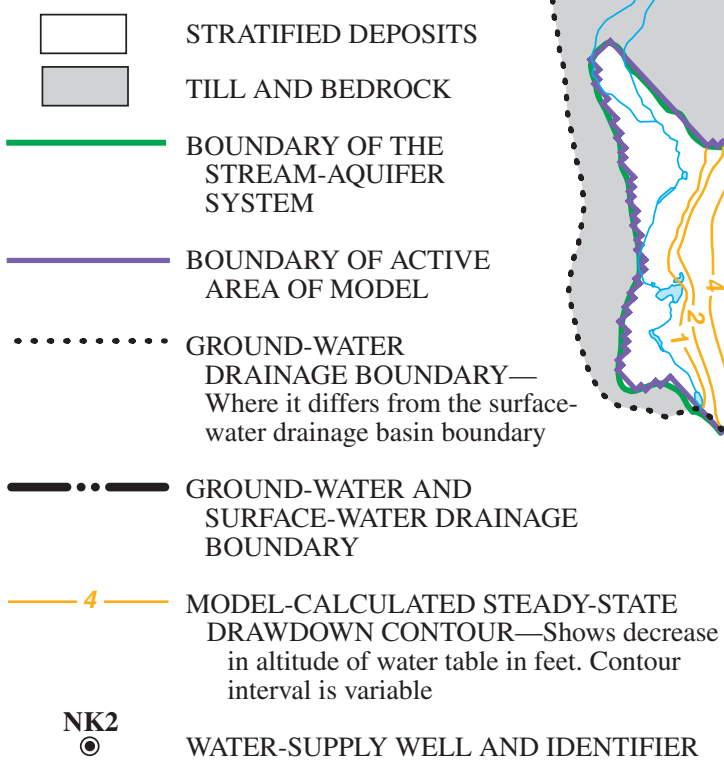

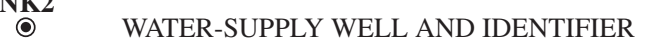

Base from U.S. Geological Survey

East Greenwich, Slocum, Wickford, Crompton, 1:24,000, 1988-94

Rhode Island state plane projection

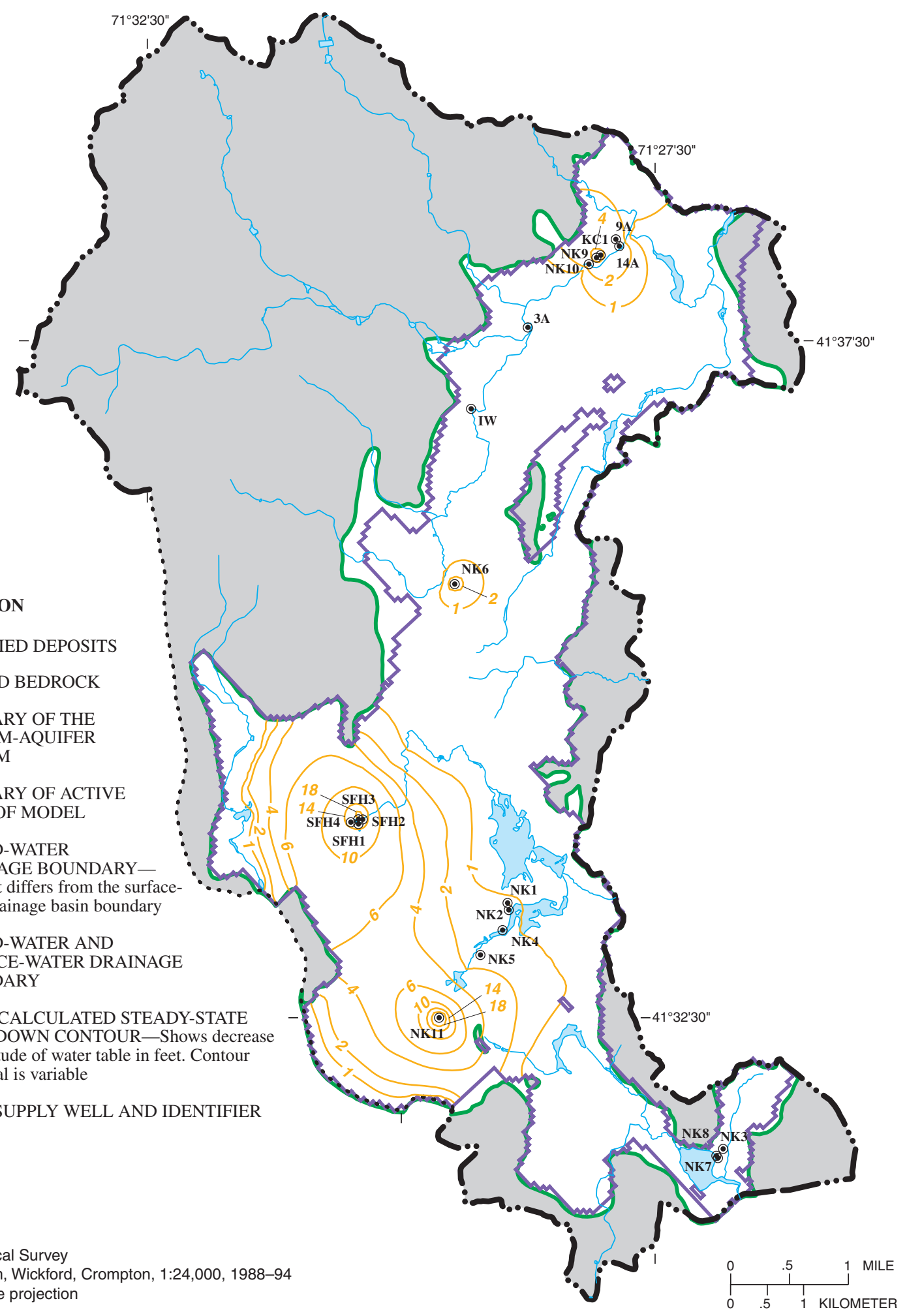

Figure 20. Model-calculated steady-state drawdowns for simulation set 6 (with State Fish Hatchery well 4 and the town of North Kingstown well 11 pumping), Hunt-Annaquatucket-Pettaquamscutt stream-aquifer system, Rhode Island. 


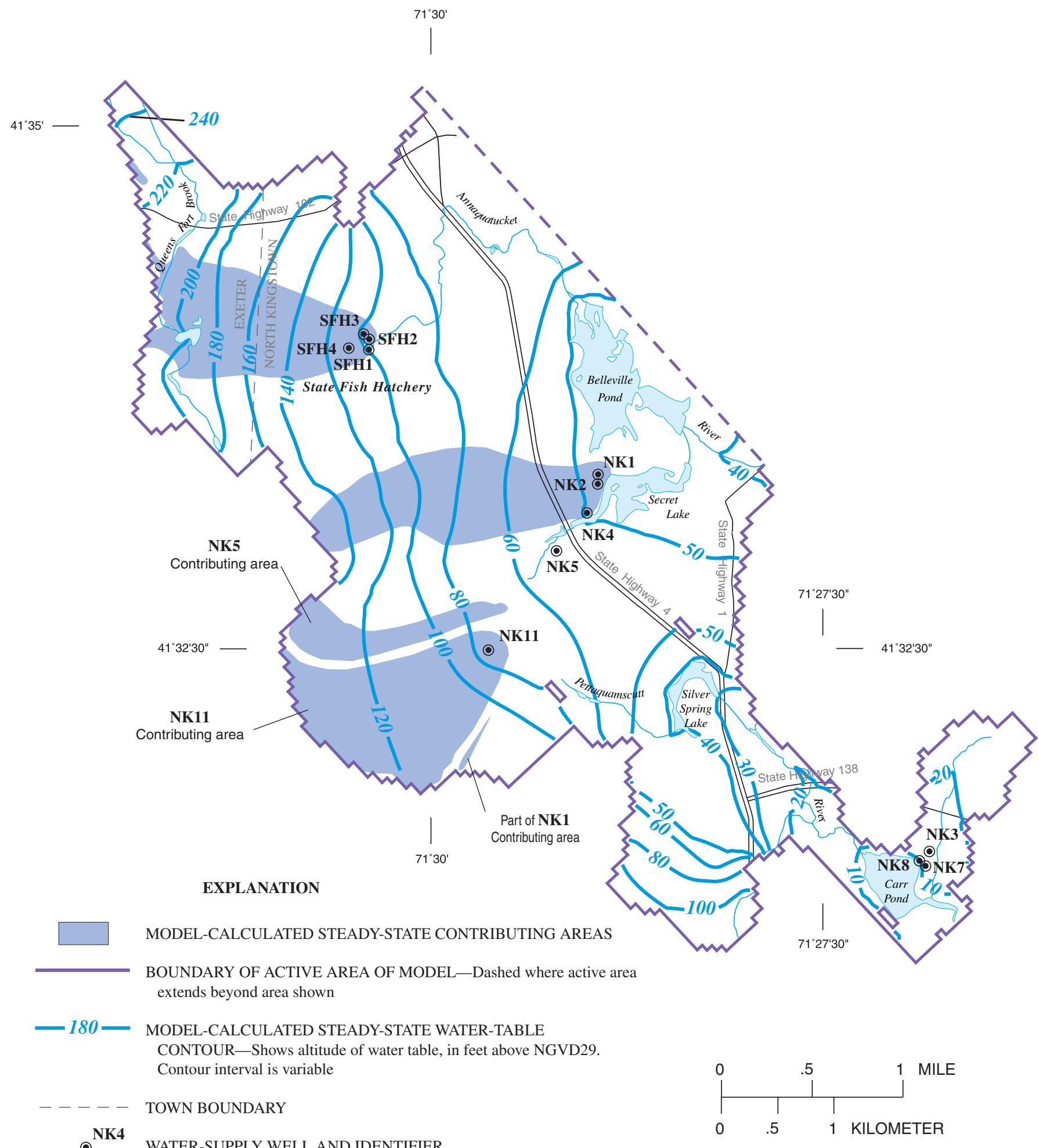

$\overbrace{}^{\text {NK4 }}$ WATER-SUPPLY WELL AND IDENTIFIER

Base from U.S. Geological Survey

East Greenwich, Slocum, Wickford, Crompton, 1:24,000, 1988-94

Rhode Island state plane projection

Figure 21. Model-calculated steady-state contributing areas to water-supply wells in the Annaquatucket River Basin for simulation set 6 (with State Fish Hatchery well 4 and the town of North Kingstown well 11 pumping), Hunt-Annaquatucket-Pettaquamscutt streamaquifer system, Rhode Island. 
in which future studies are needed to better define the hydrogeologic conditions of the aquifer.

Contributing areas delineated for wells in the Annaquatucket River Basin for the steady-state simulation are shown in figure 21. Contributing areas delineated for wells in the Hunt and Pettaquamscutt River Basins are identical to those delineated for simulation set 3 (2003 pumping rates; see fig. 16) and therefore are not shown on figure 21. Contributing areas to wells SFH1, SFH2, and SFH3 are largely unchanged from those delineated for the condition of no withdrawal at well SFH4 (that is, simulation set 3; fig. 16B) because pumping at well SFH4 does not increase the total pumping stress in the area of the hatchery by very much. The contributing area delineated for well NK11 extends to the ground-water divide between the Chipuxet and Annaquatucket River Basins and, as mentioned previously, some of the water captured by well NK11 is derived from induced ground-water flow across the boundary from the Chipuxet River Basin. Contributing areas to wells NK1, NK2, NK4, and NK5 are different for this simulation than those delineated in simulation set 3 because of the withdrawal simulated at well NK11 in this simulation.

\section{Simulations for a Drought}

Two additional simulations were made with the transient model to evaluate the effects of a drought on streamflow and ground-water levels in the Annaquatucket River Basin. Staff at the RIDEM used available precipitation data to determine that hydrologic conditions in 1957 were representative of a 1-in-25 year drought (Alisa Richardson, Rhode Island Department of Environmental Management, written commun., May 2005). Total precipitation during that year was 32.5 in. Total recharge to the aquifer during that year is estimated to have been 15.9 in., as determined from streamflow records of the Hunt River using the RORA analysis method (Rutledge, 1993). This total recharge rate is about $10 \mathrm{in.} \mathrm{lower} \mathrm{than} \mathrm{the} \mathrm{long-term}$ average recharge determined from the streamflow records for the 1941-2003 period. Month-by-month recharge rates during 1957 are shown with the long-term average monthly recharge rates in figure 22. Estimated monthly recharge rates during 1957 were lower than the long-term average monthly recharge rates for every month except April, when recharge was about 0.5 in. greater than for long-term average conditions.

Three changes were made to the transient model to simulate the drought. First, monthly recharge rates during the last 16 months of the 60-month simulation period were modified to reflect the estimated recharge conditions from September 1956 through December 1957. The period September through December 1956 was added to provide the simulated system some time to adjust to the modified drought conditions. Simulated monthly recharge rates for these 16 months were calculated by multiplying each of the calibrated-model monthly recharge rates by the ratio of the estimated 1956-1957 recharge rate to the long-term (1941-2003) average recharge rate. These ratios ranged from a minimum of 0.17 in September 1957 to a maximum of 1.16 in April 1957. The remaining two changes to the model were to modify the monthly rates of specified ground-water inflow and streamflow from the till and bedrock uplands for the last 16 months of the transient simulation (again, September 1956 through December 1957). These flows also were calculated on the basis of the ratio of the estimated 1956-1957 recharge rate to the long-term average recharge rate for each month. Other boundary conditions simulated by the model, including evapotranspiration conditions, were not modified.

Two withdrawal conditions were simulated for the drought scenario: the 2003 withdrawal rates at existing wells (simulation set 3 above) and the 2003 withdrawal rates at existing wells plus withdrawals at proposed well SFH4 and new well NK11 (simulation set 6 above). As can be seen in

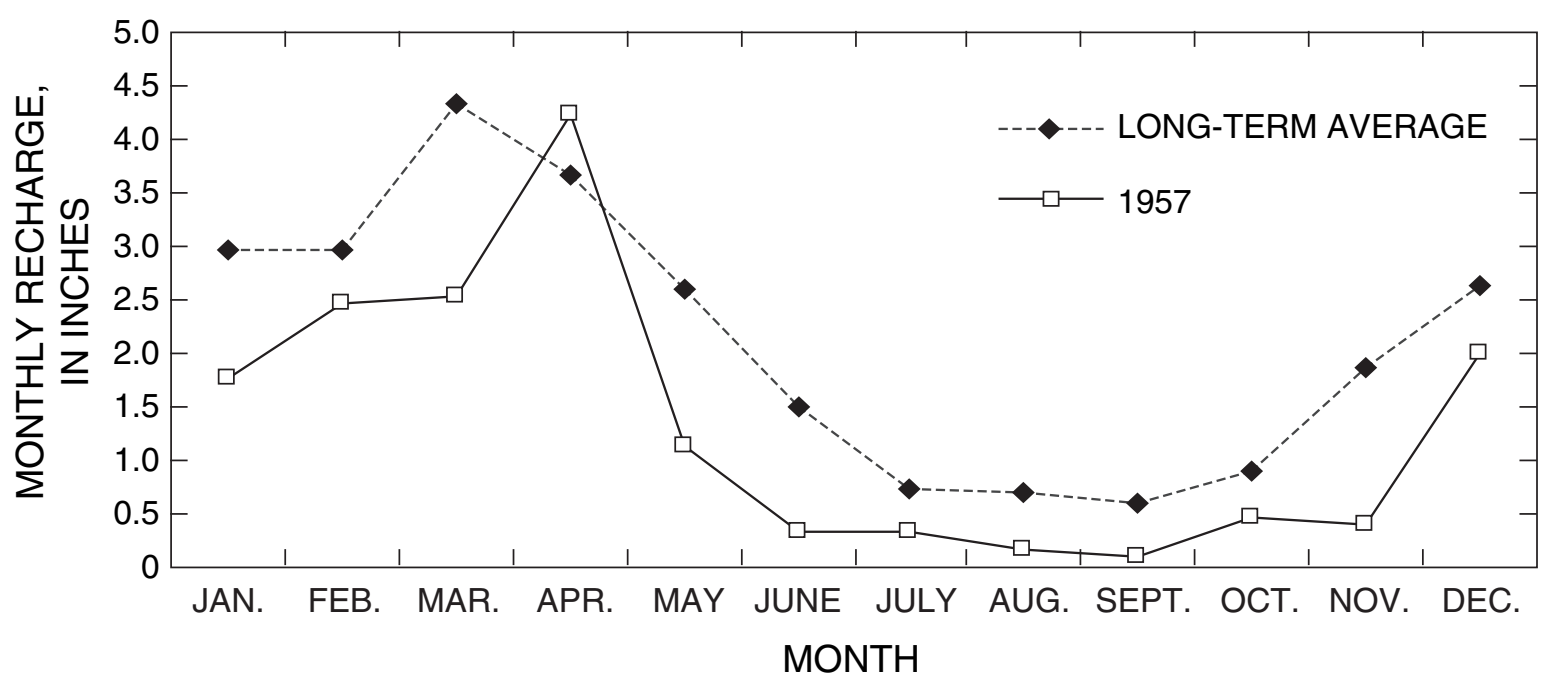

Figure 22. Long-term (1941-2003) average and 1957 monthly recharge rates, Hunt-Annaquatucket-Pettaquamscutt streamaquifer system, Rhode Island. 


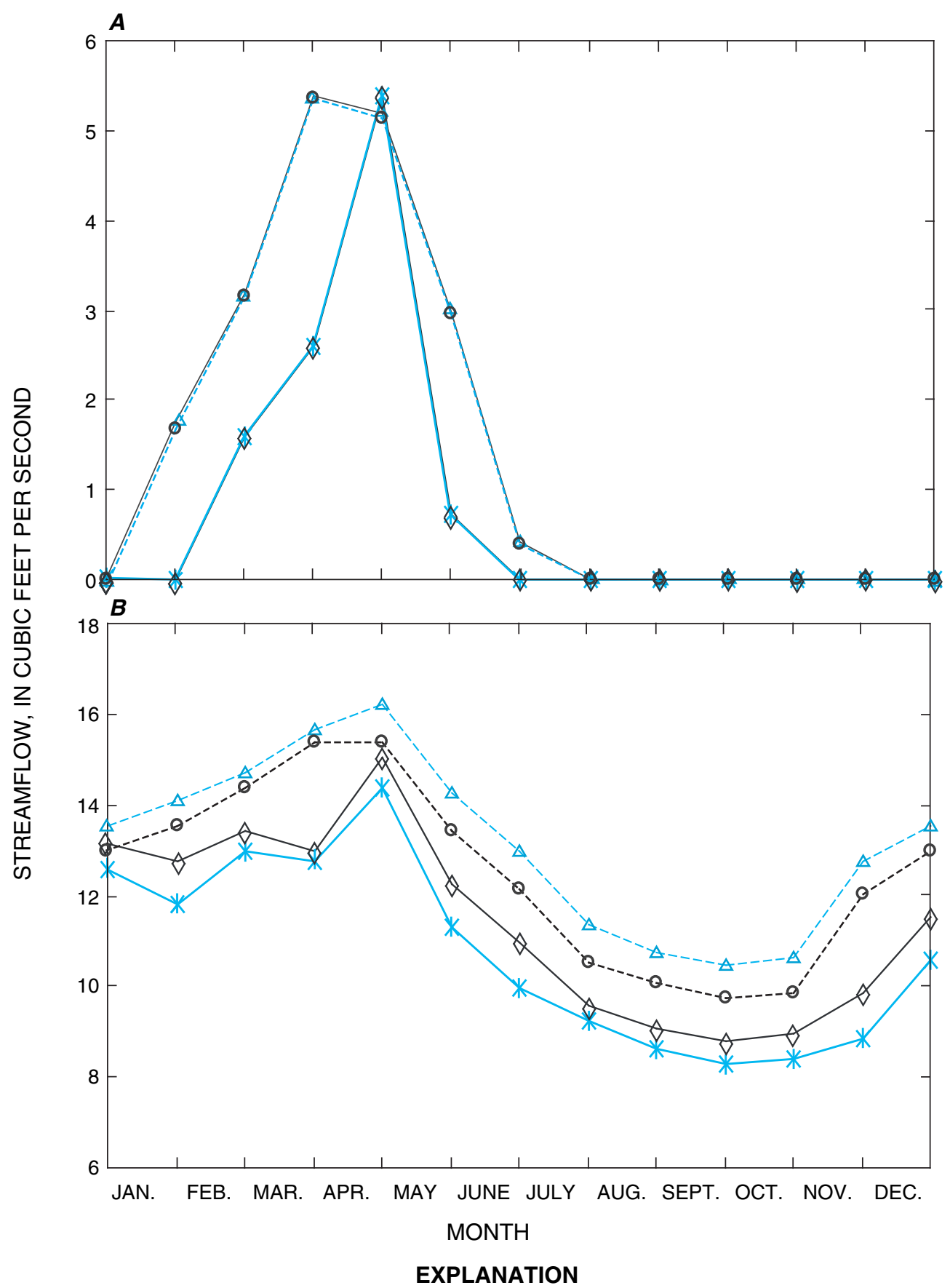

LONG-TERM AVERAGE CONDITIONS

$-\Delta_{--} . \quad$ Withdrawals at all existing wells at 2003 rates (set 3 )

--- --- Withdrawals at all existing wells at 2003 rates at State Fish Hatchery well 4 and the town of North Kingstown well 11 (set 6)

DROUGHT CONDITIONS

$\checkmark$ Withdrawals at all existing wells at 2003 rates (set 3 )

— Withdrawals at all existing wells at 2003 rates at State Fish Hatchery well 4 and the town of North Kingstown well 11 (set 6)

Figure 23. Model-calculated end-of-month streamflows at the outflow sites of $(A)$ Queens Fort Brook and (B) Annaquatucket River, Rhode Island, for simulated long-term (1941-2003) average and drought conditions. 


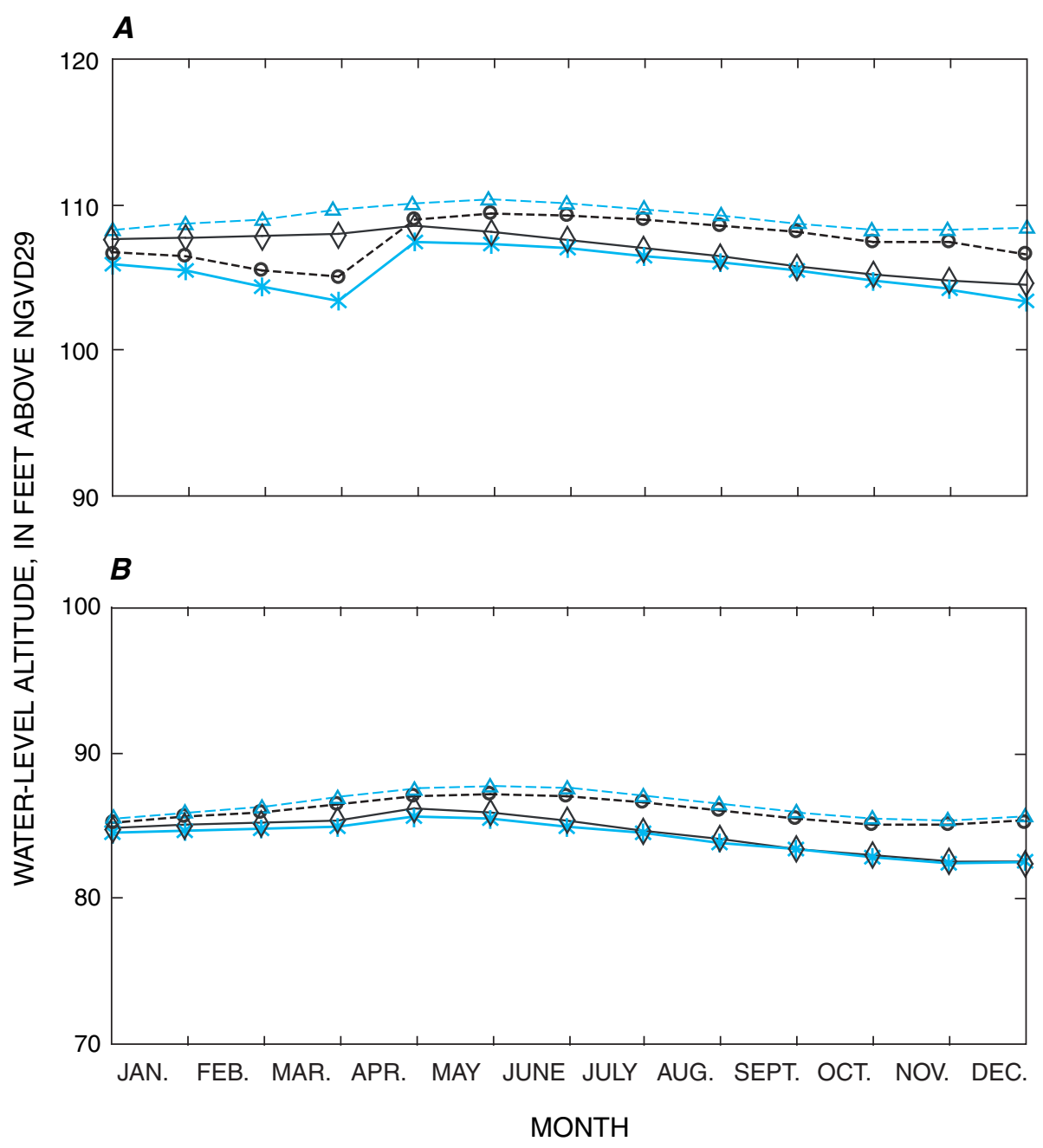

\section{EXPLANATION}

LONG-TERM AVERAGE CONDITIONS

$--\Delta_{--} \quad$ Withdrawals at all existing wells at 2003 rates (set 3)

---๑--- Withdrawals at all existing wells at 2003 rates and at State Fish Hatchery well 4 and town of North Kingstown well 11 (set 6)

\section{DROUGHT CONDITIONS}

Withdrawals at all existing wells at 2003 rates (set 3 )

* Withdrawals at all existing wells at 2003 rates and at State Fish Hatchery well 4 and the town of North Kingstown well 11 (set 6)

Figure 24. Model-calculated end-of-month ground-water levels at $(A)$ State Fish Hatchery well 4, and $(B)$ wetland site $A$, Rhode Island, for simulated long-term (1941-2003) average and drought conditions. 
figure 23, streamflows at the outflow locations of Queens Fort Brook and the Annaquatucket River are reduced by the drought conditions. The months during which there is no ground-water discharge (base flow) to Queens Fort Brook for the drought condition are January and July through December 1957, as compared to only the months of August through December for the long-term average simulation conditions. Streamflows in the Annaquatucket River are reduced by 1.2 to $2.9 \mathrm{ft}^{3} / \mathrm{s}$ for the 2003 withdrawal rates and by 1.0 to $3.1 \mathrm{ft}^{3} / \mathrm{s}$ for the 2003 withdrawal rates with SFH4 and NK11 also pumping.

Model-calculated ground-water levels at well SFH4 and at wetland site A are shown in figure 24. For the 2003 withdrawal rates, water-level declines at well SFH4 for the simulated drought (fig. 24A) range from 1.0 to $3.7 \mathrm{ft}$ more than the declines during the non-drought condition. Similar results were determined at wetland site A (fig. 24B), where waterlevel declines ranged from 0.9 to $3.0 \mathrm{ft}$ more than the declines during the non-drought condition. Water-level declines for the drought condition with 2003 withdrawal rates and pumping at wells SFH4 and NK11 are of similar magnitude at the two locations as those for the 2003 withdrawals.

\section{Limitations of Numerical Models}

The numerical models of the HAP stream-aquifer system are basin-scale models that were developed to simulate ground-water flow throughout the entire HAP system. Therefore, results of the models are most appropriate for evaluating hydrologic conditions such as ground-water-level declines, ground-water discharge rates to streams, and ground-water flow beneath wetland areas that result from the net effects of withdrawals that occur throughout the entire basin. This basinscale approach was necessary to determine the relative effects of withdrawals from the different types of wells (hatchery and production wells) pumping throughout the basin on the basinscale hydrologic system.

Model results indicate the need for improved understanding of the hydrologic conditions at the State Fish Hatchery. Conditions should be tested by the collection of water-level, lithologic, and vegetation data in the wetlands. Model results in the area of the hatchery also would be improved by the use of a finer model-grid discretization to better simulate wetland-aquifer interactions and the impacts of withdrawals on wetlands and streamflow. Use of a finer discretization could be done as part of a broader data-collection and analysis study of wetland and hydrologic conditions at and near the hatchery. As a consequence of the spatial-discretization limitations of the numerical models developed for the HAP stream-aquifer system, interpretations drawn from the study related to changes in wetland conditions simulated by the models should not be applied to other wetlands of the State.

\section{Summary and Conclusions}

In response to concern by the Rhode Island Department of Environmental Management (RIDEM) about the effects of existing and proposed withdrawals at the Lafayette State Fish Hatchery, a cooperative study by the U.S. Geological Survey and RIDEM was done to better understand hydrologic-system responses to ground-water withdrawals in the Hunt-Annaquatucket-Pettaquamscutt (HAP) stream-aquifer system of Rhode Island. System responses were determined by use of steady-state and transient numerical ground-water-flow models. Responses of the hydrologic system are described primarily by changes in simulated streamflows and groundwater levels throughout the basin and by changes to flow conditions in the aquifer in three wetland areas immediately east of the Lafayette State Fish Hatchery, which lies within the Annaquatucket River Basin in the town of North Kingstown. Ground water is withdrawn from the HAP aquifer at 14 largecapacity production wells that are operated by the town of North Kingstown, the Rhode Island Economic Development Corporation, and the Kent County Water Authority. Ground water also is withdrawn at an industrial well in the basin and at three wells operated by the RIDEM at the fish hatchery. A fourth well has been proposed for the hatchery and an additional production well is under development by the town of North Kingstown.

The numerical models used in the study were initially developed in the late 1990s as part of a larger study of the stream-aquifer system. The numerical models of the HAP stream-aquifer system are basin-scale models that were developed to simulate ground-water flow throughout the entire HAP system. The models were modified to incorporate new data made available since the original study and to meet the objectives of this study. Changes made to the models did not result in substantial changes to simulated ground-water levels, hydrologic budgets, or streamflows compared to those calculated by the original steady-state and transient models.

The primary streams of interest in the study area are the Hunt, Annaquatucket, and Pettaquamscutt Rivers and Queens Fort Brook. Total model-calculated streamflow depletions in these rivers and brook resulting from withdrawals at the production, industrial, and fish-hatchery wells pumping at average annual 2003 rates are about 4.8 cubic feet per second $\left(\mathrm{ft}^{3} / \mathrm{s}\right)$ for the Hunt River, $3.3 \mathrm{ft}^{3} / \mathrm{s}$ for the Annaquatucket River, $0.5 \mathrm{ft}^{3} / \mathrm{s}$ for the Pettaquamscutt River, and $0.5 \mathrm{ft}^{3} / \mathrm{s}$ for Queens Fort Brook. The actual amount of streamflow reduction in the Annaquatucket River caused by pumping is less, $1.1 \mathrm{ft}^{3} / \mathrm{s}$, because ground water that is pumped at the fish-hatchery wells $\left(2.2 \mathrm{ft}^{3} / \mathrm{s}\right)$ is returned to the Annaquatucket River after use at the hatchery. Model results also indicate that the Annaquatucket River loses water to the underlying aquifer in the reach from just below the fish hatchery to just above Belleville Pond; these results are supported by field data. 
One of the primary goals of the study was to evaluate the response of the hydrologic system to simulated withdrawals at the proposed well at the fish hatchery. Withdrawal rates at the proposed well would range from zero during April through September of each year to a maximum of 260 gallons per minute [about 0.4 million gallons per day (Mgal/d)] in March of each year. The average annual withdrawal rate at the fish hatchery resulting from the addition of the proposed well would increase by $0.13 \mathrm{ft}^{3} / \mathrm{s}$, or about 5 percent of the 2003 withdrawal rate. The increased pumping rate at the hatchery would further reduce the average annual flow in Queens Fort Brook by less than $0.05 \mathrm{ft}^{3} / \mathrm{s}$ and in the Annaquatucket River by about $0.1 \mathrm{ft}^{3} / \mathrm{s}$ (which includes some model error).

A new production well in the Annaquatucket River Basin is under development by the town of North Kingstown. A simulated pumping rate of $1.0 \mathrm{Mgal} / \mathrm{d}\left(1.6 \mathrm{ft}^{3} / \mathrm{s}\right)$ at this new well resulted in additional streamflow depletions over those calculated for the 2003 withdrawal conditions of 0.8 and $0.2 \mathrm{ft}^{3} / \mathrm{s}$ in the Annaquatucket and Pettaquamscutt Rivers, respectively. The source of water for about 30 percent of the well's pumping rate, or about $0.5 \mathrm{ft}^{3} / \mathrm{s}$, is derived from groundwater inflow from the Chipuxet River Basin across a natural ground-water drainage divide that separates the Annaquatucket and Chipuxet River Basins; the remaining $0.1 \mathrm{ft}^{3} / \mathrm{s}$ of simulated pumping consists of reduced evapotranspiration from the water table.

Model-calculated changes in water levels in the aquifer for the various withdrawal conditions simulated in this study indicate that ground-water-level declines caused by pumping are generally less than 5 feet (ft). However, ground-waterlevel declines of as much as $20 \mathrm{ft}$ were calculated near the fish hatchery and of as much as $18 \mathrm{ft}$ were calculated near the new production well in the Annaquatucket River Basin. The larger water-level declines in these two areas are attributed to relatively low values of the transmissivity of the aquifer in these two areas. Average annual ground-water-level declines in the aquifer resulting from the increased withdrawal in the hatchery area are not substantially greater than those for the 2003 average annual pumping conditions.

Model-calculated hydrologic budgets for the aquifer in the three wetland areas near the fish hatchery indicate that the total inflow rate to each area is reduced by a maximum of $0.3 \mathrm{ft}^{3} / \mathrm{s}$ for the 2003 average annual pumping conditions; these reductions are a maximum of 13 percent of the total inflow rate to each area for non-pumping conditions. Modelcalculated rates of ground-water evapotranspiration from the wetlands are very small (less than $0.1 \mathrm{ft}^{3} / \mathrm{s}$ in all cases) for both pumping and non-pumping conditions. These low rates of ground-water evapotranspiration result from the fact that model-calculated ground-water levels in the wetland areas are generally below the model-simulated 4-ft maximum depth below land surface at which ground-water evapotranspiration is assumed to occur. Ground-water-level data generally are lacking to support or refute these simulated ground-water levels in the wetlands. The rates of reductions in ground-water flows to the wetland areas are not substantially different for the proposed additional withdrawals at the hatchery.

The transient model also was used to evaluate the effects of a simulated drought condition on streamflow and groundwater levels. The simulated drought condition was based on hydrologic conditions during 1957, which was determined by the RIDEM to represent a 1-in-25 year drought. For the withdrawal conditions evaluated, the simulated drought caused model-calculated monthly streamflows in the Annaquatucket River to be reduced by $1.0 \mathrm{ft}^{3} / \mathrm{s}$ to $3.1 \mathrm{ft}^{3} / \mathrm{s}$ more than those streamflows calculated for long-term average simulation conditions (that is, non-drought conditions). Model-calculated ground-water levels at the proposed well site at the fish hatchery decline by $1.0 \mathrm{ft}$ to $3.7 \mathrm{ft}$ for the drought condition compared to those levels calculated for nondrought conditions.

Results of the study must be viewed within the limitations of the quality of the data that are available for the Hunt-Annaquatucket-Pettaquamscutt stream-aquifer system and representation of the system with simulation models. Uncertainties in the model simulations result from a variety of factors, including uncertainties in the exact values of the hydraulic properties of the aquifers, rates of recharge to the aquifer, and the approaches used to simulate the many features of the hydrologic system (streams, evapotranspiration, flow conditions at ground-water drainage divides, and so forth).

The precision of the numerical models used in this study to determine hydrologic-system responses to ground-water withdrawals could benefit from refinement of localized information on the wetlands and the geology of the area near the fish hatchery. Model results in the area of the hatchery also would be improved by the use of a finer model-grid discretization to better simulate wetland-aquifer interactions and the impacts of withdrawals on wetlands and streamflow. Use of a finer discretization could be done as part of a broader datacollection and analysis study of wetland and hydrologic conditions at or near the hatchery. As a consequence of the spatial-discretization limitations of the numerical models developed for the HAP stream-aquifer system, the ability of the numerical models to predict hydrologic responses in the vicinity of the hatchery wells is limited. Furthermore, groundwater-flow conditions near the ground-water drainage divide that separates the Annaquatucket and Chipuxet River Basins are largely unknown. The understanding of hydrologic conditions near this divide would be improved by collection of hydrogeologic data in that area. 


\section{References Cited}

Barlow, P.M., and Dickerman, D.C., 2001, Numericalsimulation and conjunctive-management models of the Hunt-Annaquatucket-Pettaquamscutt stream-aquifer system, Rhode Island: U.S. Geological Survey Professional Paper 1636, 88 p.

Dickerman, D.C., and Barlow, P.M., 1997, Water-table conditions and stream-aquifer interaction in the HuntAnnaquatucket-Pettaquamscutt aquifer, central Rhode Island, October 7-9, 1996: U.S. Geological Survey Water-Resources Investigations Report 97-4167, 1 sheet.

Fay, Spofford, and Thorndike, 2005, Well 11 pump test results, new public water supply, North Kingstown, R.I., prepared for Town of North Kingstown Water Department (January 2005): Burlington, Massachusetts, variously paginated.

Hahn, G.W., 1959, Ground-water map of the Slocum quadrangle, Rhode Island: Rhode Island Water Resources Coordinating Board GWM-2, 1 sheet, scale 1:24,000.

Harbaugh, A.W., 1990, A computer program for calculating subregional water budgets using results from the U.S. Geological Survey modular three-dimensional finite-difference ground-water flow model: U.S. Geological Survey Open-File Report 90-392, 24 p.

Harbaugh, A.W., Banta, E.R., Hill, M.C., and McDonald, M.G., 2000, MODFLOW-2000, the U.S. Geological Survey modular ground-water model-User guide to modularization concepts and the ground-water flow process: U.S. Geological Survey Open-File Report 00-92, 121 p.

Harbaugh, A.W., and McDonald, M.G., 1996, User's documentation for MODFLOW-96, an update to the U.S. Geological Survey modular finite-difference groundwater flow model: U.S. Geological Survey Open-File Report 96-485, 56 p.
Johnson, K.E., and Marks, L.Y., 1959, Ground-water map of the Wickford quadrangle, Rhode Island: Rhode Island Water Resources Coordinating Board GWM-1, 1 sheet, scale 1:24,000.

Kliever, J.D., 1995, Hydrologic data for the Usquepaug-Queen River Basin, Rhode Island: U.S. Geological Survey Open-File Report 95-305, 68 p.

McDonald, M.G., and Harbaugh, A.W., 1988, A modular three-dimensional finite-difference ground-water flow model: U.S. Geological Survey Techniques of Water-Resources Investigations, book 6, chap. A1, 586 p.

Pollock, D.W., 1994, User's guide for MODPATH/MODPATH-PLOT, version 3-A particle tracking post-processing package for MODFLOW, the U.S. Geological Survey finite-difference ground-water flow model: U.S. Geological Survey Open-File Report 94-464, 249 p.

Prudic, D.E., 1989, Documentation of a computer program to simulate stream-aquifer relations using a modular, finite-difference, ground-water flow model: U.S. Geological Survey Open-File Report 88-729, 113 p.

Rosenshein, J.S., Gonthier, J.B., and Allen, W.B., 1968, Hydrologic characteristics and sustained yield of principal ground-water units, Potowomut-Wickford area, Rhode Island: U.S. Geological Survey Water-Supply Paper 1775, $38 \mathrm{p}$.

Rutledge, A.T., 1993, Computer programs for describing the recession of ground-water discharge and for estimating mean ground-water recharge and discharge from streamflow records: U.S. Geological Survey Water-Resources Investigations Report 93-4121, 45 p. 



\section{APPENDIX 1:}

\section{Withdrawals from Selected Production Wells, 1999-2004}


Table 1.1. Summary of monthly withdrawals from selected production wells in the Hunt-Annaquatucket-Pettaquamscutt streamaquifer system, Rhode Island, 1999-2004.

[Withdrawals are in million gallons. RIEDC, Rhode Island Economic Development Corporation; KCWA, Kent County Water Authority; NK, North Kingstown. Well locations shown in figure 1]

\begin{tabular}{|c|c|c|c|c|c|c|c|c|c|c|c|c|}
\hline Year & January & February & March & April & May & June & July & August & September & October & November & December \\
\hline \multicolumn{13}{|c|}{ RIEDC well 9A } \\
\hline 2000 & 8.9 & 4.9 & 5.9 & 4.0 & 5.5 & 2.6 & .0 & .0 & .0 & .0 & .0 & .0 \\
\hline 2001 & .8 & 5.8 & 7.1 & 7.1 & 9.6 & 4.9 & 10.5 & 11.6 & 9.3 & 11.3 & .0 & 6.4 \\
\hline 2004 & 7.2 & 6.0 & 6.3 & 6.8 & 7.1 & 7.2 & 7.2 & 9.3 & 7.1 & 4.8 & 4.8 & 6.4 \\
\hline \multicolumn{13}{|c|}{ RIEDC well 14A } \\
\hline 1999 & 9.1 & 4.3 & 2.5 & 5.4 & 5.7 & 7.3 & 9.9 & 9.9 & 6.7 & 2.9 & 9.6 & 4.8 \\
\hline 2000 & .0 & .0 & 9.1 & 9.4 & 4.0 & 9.3 & 22.6 & 11.9 & 13.9 & 16.0 & 11.4 & 13.3 \\
\hline 2001 & 14.7 & 5.6 & 5.1 & 4.7 & 6.1 & 10.3 & 3.9 & 7.4 & 9.5 & .2 & 10.3 & 6.4 \\
\hline 1999 & 3.6 & 7.3 & 5.2 & 7.5 & 5.1 & 6.9 & 11.0 & 9.4 & 8.5 & 7.2 & .0 & 5.9 \\
\hline 2000 & 10.3 & 15.0 & 6.0 & 6.3 & 4.4 & 6.7 & 7.4 & 12.0 & 7.3 & 4.3 & 7.0 & 8.1 \\
\hline 2001 & 6.2 & 5.4 & 6.0 & 5.4 & 7.3 & 8.8 & 9.7 & 8.0 & 6.3 & 8.2 & 8.6 & 5.4 \\
\hline 2002 & 6.1 & 6.4 & 5.9 & 6.4 & 5.2 & 7.1 & 9.3 & 10.1 & 5.9 & 5.5 & 4.3 & 3.9 \\
\hline 2003 & 5.1 & 4.9 & 7.0 & 9.5 & 8.5 & 7.7 & 9.2 & 9.9 & 5.9 & 3.2 & 8.3 & 1.8 \\
\hline 2004 & 6.2 & 5.5 & 4.9 & 4.1 & 6.6 & 7.8 & 8.9 & 4.7 & 7.9 & 5.6 & 5.6 & 5.4 \\
\hline \multicolumn{13}{|c|}{ KC well 1} \\
\hline 1999 & 34.0 & 29.3 & 31.0 & 7.0 & 26.8 & 34.2 & 42.2 & 35.8 & 13.4 & 3.5 & 3.5 & 2.3 \\
\hline 2000 & 27.1 & 27.9 & 28.6 & 31.0 & 17.2 & 14.4 & 10.7 & 3.0 & 1.7 & .4 & .8 & .4 \\
\hline 2001 & .8 & .7 & 14.8 & 24.1 & 24.0 & 19.3 & 29.3 & 21.3 & 19.1 & 18.6 & 11.3 & 13.8 \\
\hline 2002 & 0 & 0 & 3.4 & 8.1 & 12.8 & 22.4 & 45.4 & 24.9 & 12.4 & 18.0 & 31.2 & 35.4 \\
\hline 2003 & 29.5 & 28.0 & 17.6 & 31.1 & 37.6 & 35.3 & 40.7 & 36.5 & 37.3 & 35.2 & 32.0 & 34.2 \\
\hline 2004 & 30.9 & 28.2 & 32.8 & 28.3 & 29.4 & 31.6 & 6.4 & 37.1 & 11.1 & 11.3 & 17.3 & 18.9 \\
\hline \multicolumn{13}{|c|}{ NK well 10} \\
\hline 1999 & 0 & 0 & 0 & 0 & 0 & 0 & 0 & 0 & 0 & 0 & 0 & 0 \\
\hline 2000 & 0 & 0 & 0 & 0 & 0 & 0 & 0 & 0 & 0 & 0 & 0 & 0 \\
\hline 2001 & 0 & 0 & 0 & 0 & 0 & 0 & 0 & 0 & 0 & 0 & 0 & 0 \\
\hline 2002 & 0 & 0 & 0 & 0 & 0 & 0 & 0 & 0 & 0 & 0 & 0 & 0 \\
\hline 2003 & 0 & 0 & 0 & 0 & 0 & 0 & 0 & 0 & 0 & 0 & 0 & 0 \\
\hline 2004 & 0 & 1.9 & 1.7 & 7.4 & 7.5 & 9.7 & 50.7 & 4.3 & 33.6 & 25.3 & 23.9 & 20.3 \\
\hline \multicolumn{13}{|c|}{ NK well 6} \\
\hline 1999 & 6.6 & 9.3 & 11.3 & 11.6 & 15.4 & 23.9 & 23.2 & 16.0 & 12.1 & 6.5 & 11.2 & 5.6 \\
\hline 2000 & 3.6 & 3.1 & 6.1 & 8.0 & 5.8 & 15.6 & 21.4 & 13.4 & 10.4 & 10.0 & 9.0 & 9.8 \\
\hline 2001 & 11.9 & 6.6 & 11.7 & 14.9 & 21.6 & 17.5 & 21.8 & 21.5 & 19.0 & 20.5 & 18.5 & 18.7 \\
\hline 2002 & 22.1 & 21.4 & 23.6 & 24.2 & 28.6 & 24.7 & 31.2 & 28.6 & 25.4 & 23.8 & 17.7 & 15.1 \\
\hline 2003 & 16.8 & 15.7 & 20.9 & 18.1 & 19.4 & 19.9 & 24.0 & 21.7 & 20.6 & 22.0 & 17.9 & 16.9 \\
\hline 2004 & 15.5 & 17.3 & 7.7 & 12.5 & 23.3 & 25.2 & 19.3 & 22.0 & 16.5 & 16.5 & 10.9 & 11.3 \\
\hline
\end{tabular}


Table 1-1. Summary of monthly withdrawals from selected production wells in the Hunt-Annaquatucket-Pettaquamscutt streamaquifer system, Rhode Island, 1999-2004._-Continued

[Withdrawals are in million gallons. RIEDC, Rhode Island Economic Development Corporation; KCWA, Kent County Water Authority; NK, North Kingstown. Well locations shown in figure 1]

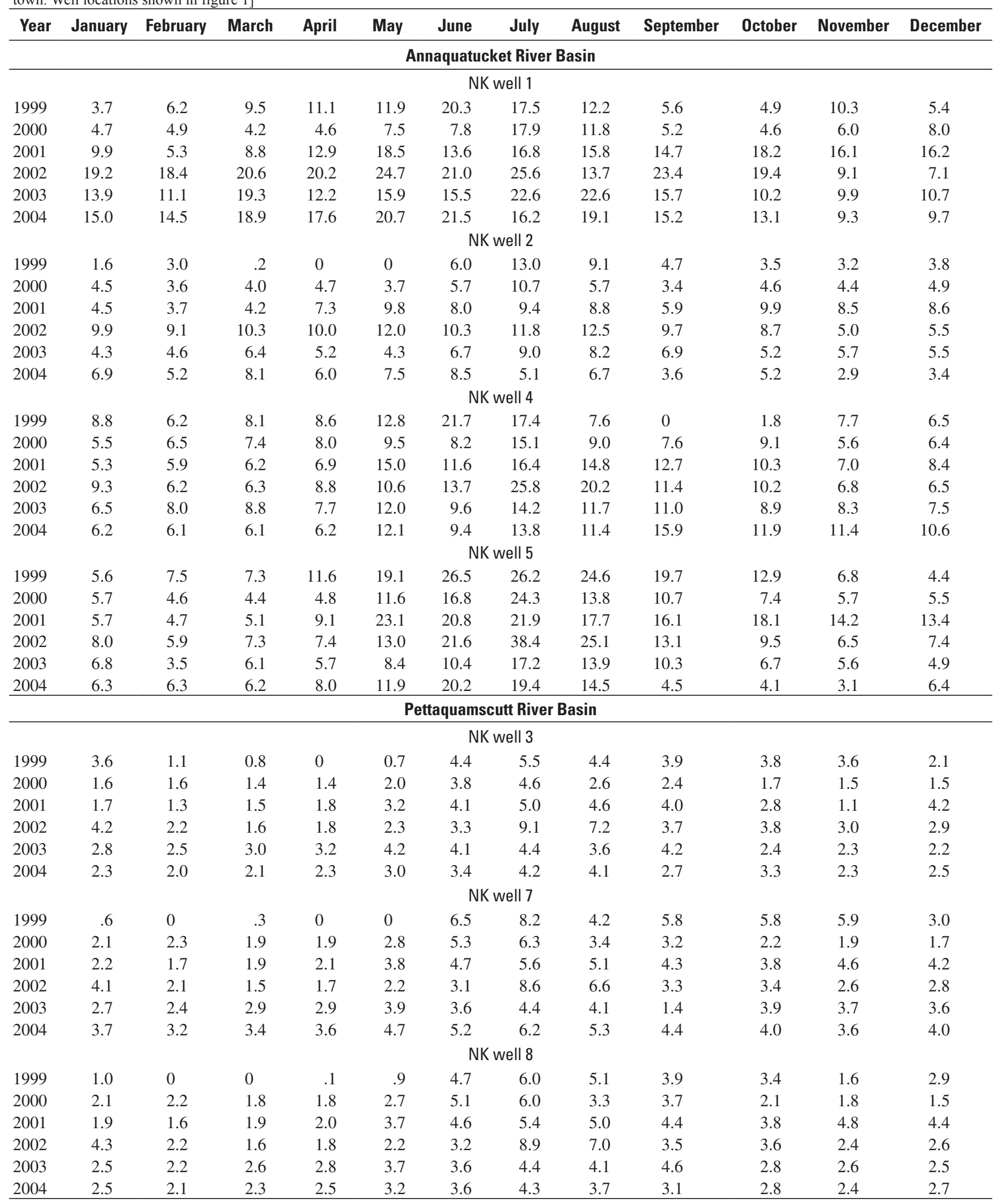





\section{For additional information call or write to:}

Deputy Director, U.S. Geological Survey

Massachusetts-Rhode Island Water Science Center 275 Promenade Street

Providence, RI 02908

(401) 331-9050

http://ri.water.usgs.gov 
